UNIVERSIDADE DE SÃO PAULO

FFCLRP - DEPARTAMENTO DE BIOLOGIA

PROGRAMA DE PÓS-GRADUAÇÃO EM BIOLOGIA COMPARADA

\title{
Biologia reprodutiva do caranguejo simbionte Pachycheles monilifer (Crustacea, Decapoda, Anomura): relação entre potencial reprodutivo e substrato.
}

\section{Isabela Carnielli Leone}

Dissertação apresentada à Faculdade de Filosofia, Ciências e Letras de Ribeirão Preto da USP, como parte das exigências para a obtenção do título de Mestre em Ciências, Área: Biologia Comparada.

RIBEIRÃO PRETO - SP 
UNIVERSIDADE DE SÃO PAULO

FFCLRP - DEPARTAMENTO DE BIOLOGIA

PROGRAMA DE PÓS-GRADUAÇÃO EM BIOLOGIA COMPARADA

\section{Biologia reprodutiva do caranguejo simbionte Pachycheles monilifer (Crustacea, Decapoda, Anomura): relação entre potencial reprodutivo e substrato.}

\section{Isabela Carnielli Leone}

Orientador: Prof. Dr. Fernando Luis Medina Mantelatto

Dissertação apresentada à Faculdade de Filosofia, Ciências e Letras de Ribeirão Preto da USP, como parte das exigências para a obtenção do título de Mestre em Ciências, Área: Biologia Comparada.

RIBEIRÃO PRETO - SP 
Autorizo a reprodução e divulgação total ou parcial deste trabalho, por qualquer meio convencional ou eletrônico, para fins de estudo e pesquisa, desde que citada a fonte.

Leone, I. C.

Biologia reprodutiva do caranguejo simbionte Pachycheles monilifer (Crustacea, Decapoda, Anomura): relação entre potencial reprodutivo e substrato.

93pp.

Dissertação apresentada à Faculdade de Filosofia, Ciências e Letras de Ribeirão Preto da Universidade de São Paulo, como parte das exigências para a obtenção do título de Mestre em Ciências, Área: Biologia Comparada.

Orientador: prof. Dr. Fernando Luis Medina Mantelatto
1. Simbiose
2. Potencial reprodutivo
3. Substrato 


\section{Agradecimentos}

Ao Prof. Dr. Fernando L. M. Mantelatto por abrir as portas do seu laboratório e aceitar desenvolver um projeto que já não era mais sua principal linha de pesquisa. Obrigada pela orientação, confiança, por todo o conhecimento científico transmitido e por muitas vezes me colocar de volta ao foco do meu trabalho. Obrigada por tudo!!

À Coordenação de Aperfeiçoamento de Pessoal de Nivel Superior (CAPES) pela bolsa concedida durante o período do meu mestrado. À Capes/PROAP pelo auxílio para diversas atividades durante o desenvolvimento do projeto.

À Fundação de Amparo à Pesquisa do Estado de São Paulo (FAPESP) pelos projetos que proporcionaram todo o apoio financeiro e logístico, direta ou indiretamente, para o desenvolvimento desta pesquisa junto ao Laboratório de Bioecologia e Sistemática de Crustáceos (LBSC), concedidos ao e/ou coordenados por Prof. Dr. Fernando Mantelatto: FAPESP - Procs. No 1998/07454-5 e 2002/08178-9 (Projetos Individuais de Pesquisa), 2010/50188-8 (Projeto Temático Biota), 2009/54931-0 (Projeto Coleções Científicas); ao Conselho Nacional de Desenvolvimento Científico e Tecnológico (CNPq) - Procs. 472746/2004-9，471794/2006-6，473050/2007-2, 471011/2011-8 (Edital Universal, Auxilio Individual a Pesquisa), 491490/2004-6, 490122/2006-0, 490353/2007-0 (Projetos Cooperação Internacional); 301359/2007-5, 302748/2010-5 (Produtividade em Pesquisa). À Universidade de São Paulo e ao Programa de Pós Graduação em Biologia Comparada da Faculdade de Filosofia, Ciências e Letras de Ribeirão Preto pelo ensino de qualidade, assistência e suporte. Aos professores e funcionários desta Faculdade, em particular os professores João Atílio Jorge, Marlene Sofia Arcifa Froehlich e Wagner Eustáquio Paiva Avelar pela participação na banca da minha qualificação.

Agradeço também todos os funcionários do Departamento de Biologia e da Seção de Pós-graduação que estão sempre prontos a ajudar. 
Ao prof. Rogério Costa (Cebola) por ter me proporcionado acesso aos dados abióticos do seu trabalho na região de Ubatuba.

À prof. Setuko Masunari pela assessoria no relatório parcial.

Ao pessoal do lab que me ajudou nas coletas e triagens dos animais: Camila, Tati, Kelps, Natália, Fabrício, Raquel, Kana, Mari, Ligeira e os alunos da turma da Biologia46. Ao técnico Álvaro Costa por toda ajuda logística durante as coletas e a preparação para as viagens de campo.

À todos os membros do Laboratório de Bioecologia e Sistemática de Crustáceos (LBSC): Rafa, Léo, Mari, Ivana, Mateus, Natália, Kana, Raquel, Nicole, Vanda, Fabrício, Douglas, Tati, Kelps, Abner, Camila, Ligeira, Lucas, Caio, Bárbara, Juliana, Ana Luisa por toda a ajuda proporcionada, seja pela ajuda nas tarefas diárias ou por uma conversa mais séria. Obrigada a todos!! Agradeço em especial ao Rafa, Tati, Kana, Kelps, Natália e Mari pela ajuda durante o aprendizado das técnicas moleculares. Ao Léo e Raquel, obrigada pela foto. Obrigada à Kana e Ná pela ajuda na interpretação dos dados moleculares. À Ná, Tati e Kelps pela ajuda na submissão das sequências para o Genbank.

Ao Dr. Rafael Robles pelas inúmeras conversas, mesmo que informais, sempre me fizeram olhar um determinado assunto sob um outro ponto de vista, além da amizade construída e sem falar nos milhões de cafés!

À Dra. Mariana Terossi por sempre estar disposta a me ajudar, desde as coisas mais simples (como fazer as 'casinhas' para os embriões) até as discussões mais sérias, como estatística e assuntos relacionados à ecologia reprodutiva. Obrigada por toda ajuda desde que cheguei no lab, Mary Jane!!

Ao Fabrício com todo seu conhecimento em estatística. Muito obrigada por toda a paciência e disposição para me auxiliar nas análises dos dados. Nunca hesitou em ter que repetir várias vezes, muito obrigada!

À Kelps, além da amizade construída durante esse tempo, obrigada por sempre estar disposta à tudo, seja na molecular ou na interpretação dos resultados, além de sempre oferecer ajuda, mesmo não sabendo como o fazer. Pelos inúmeros almoços, açaís e aulas de natação nessa reta final, obrigada! 
Às 'chicas superpoderosas': Ná e Nicole obrigada por todo o apoio e incentivo que sempre me deram desde o começo. Obrigada pela amizade que sei que vai permanecer e também por alegrarem meus dias de trabalho. Ná, agradeço imensamente a ajuda e correções na interpretação dos dados moleculares e, principalmente, pelas infinitas conversas e todo seu pensamento positivo!!

À Vanessa que desde o início sempre esteve ao meu lado, me ajudando, me incentivando, me dando apoio para sempre prosperar! Obrigada pela amizade $e$ preocupação.

Ao meu querido Alê que, além de todo carinho e amor, me auxiliou em algumas das coletas e triagem do material. Obrigada meu amor, pelo apoio sempre!

À minha família, em especial meus pais Eliana e Mario Umberto e minha irmã Leticia, assim como amigos, tios, primos e minhas avós, que apesar de muitas vezes não compreenderem muito bem meu trabalho, sempre me deram suporte $e$ estiveram ao meu lado em todas minhas decisões. O que me tornei hoje é fruto de todas as coisas boas que recebo de vocês! Muito obrigada por serem vocês!

Por fim, agradeço a todos que de certa forma contribuíram para a realização deste trabalho, sem a ajuda de todos nada seria possível! 
"What is a scientist after all? It is a curious man looking through a keyhole, the keyhole of nature, trying to know what's going on" Jacques Yves Cousteau 


\section{Sumário}

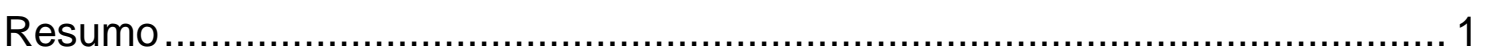

Abstract t.1.1.

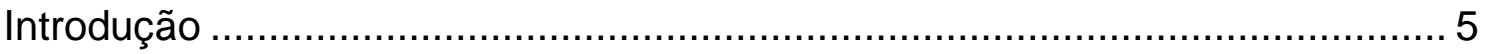

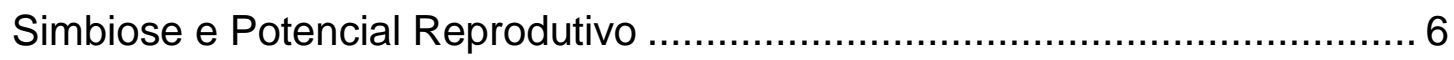

Crustáceo Decapoda como modelo de estudo ………................................ 8

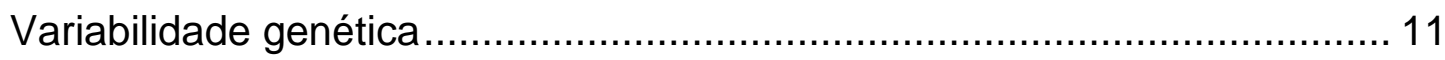

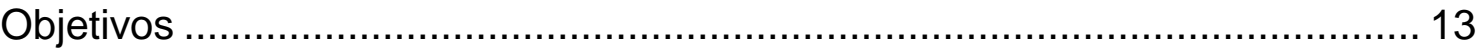

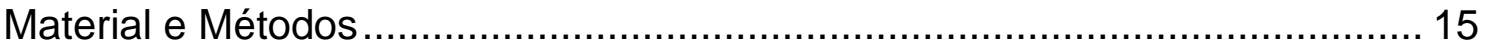

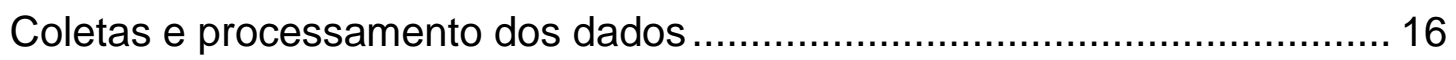

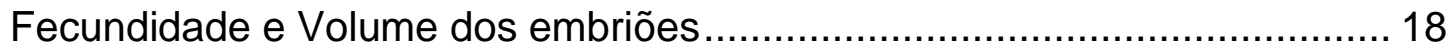

Investimento Reprodutivo (RO) …....................................................... 19

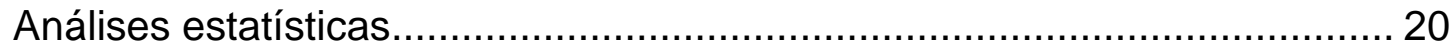

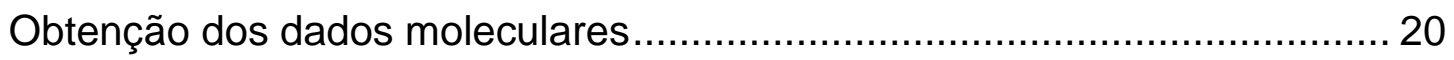

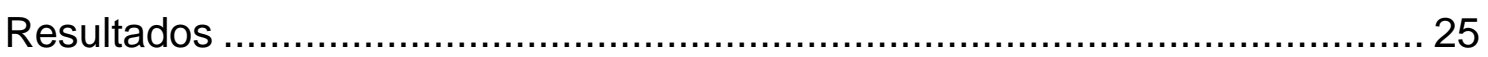

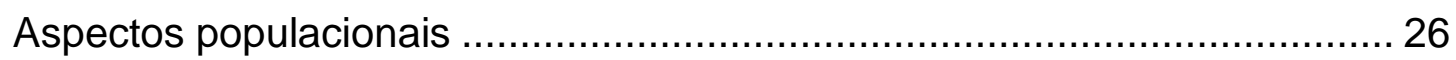

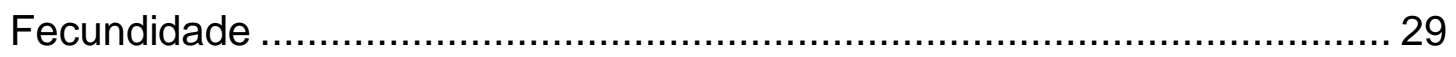

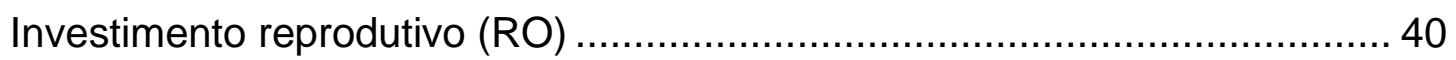

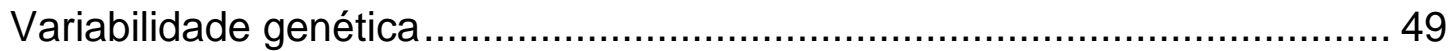

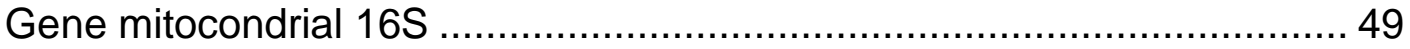

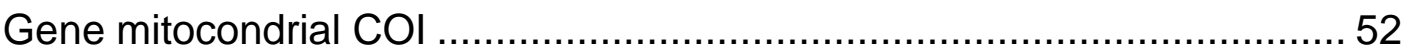

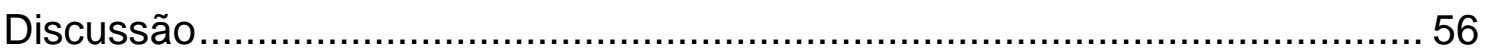

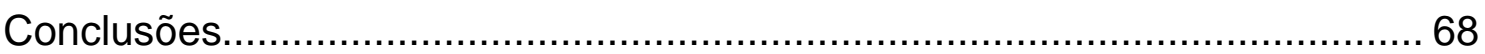

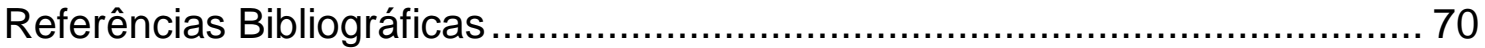


Os crustáceos estão entre os invertebrados marinhos mais diversos e tendem a se associar com outros organismos a fim de encontrar abrigo, oferta de alimento e um lugar seguro para reprodução. Aspectos reprodutivos como fecundidade, tamanho dos embriões e energia investida na reprodução são os principais parâmetros para a compreensão da história natural de uma espécie e/ou população. Assim, esse trabalho foi desenvolvido no sentido de investigar tais parâmetros e a influência do tipo de substrato ocupado. A espécie utilizada como modelo de estudo foi o caranguejo porcelanídeo Pachycheles monilifer coletado em dois substratos biológicos diferentes, no briozoário Schizoporella errata no píer do Itaguá e no poliqueto Phragmatopoma caudata na praia Grande, ambas as paias localizadas em Ubatuba, litoral norte de SP. Somente os embriões em estágio inicial de desenvolvimento foram utilizados para os cálculos de fecundidade e investimento reprodutivo (RO). Os embriões foram contados e medidos sob esteromicroscópio. Para obtenção do RO foram utilizados os pesos secos das fêmeas ovígeras e das massas de embriões, previamente secos em estufa. Além dos aspectos reprodutivos, análises de distância genética também foram realizadas pelo sequenciamento de genes mitocôndrias (16S e COI) de exemplares de $P$. monilifer. A estimativa da porcentagem de variação genética intra e interespecífica, a possibilidade de fluxo gênico entre indivíduos de diferentes praias do estado de São Paulo foram verificadas. A partir desses dados confirmou-se a validade da espécie, assim como o fluxo gênico contínuo entre indivíduos dessas duas praias. A baixa divergência genética permite concluir que as diferenças reprodutivas encontradas são, portanto um reflexo das condições proporcionadas pelo ambiente. Os animais simbiontes do briozoário, assim como as fêmeas ovígeras, são maiores que os associados ao poliqueta e também possuem maior fecundidade e investimento reprodutivo, porém não foram encontradas diferenças em relação ao tamanho dos embriões. No substrato do briozoário o estresse reprodutivo parece ser menor que no substrato do poliqueto, já que aquele substrato proporciona um ambiente fisicamente mais estável para os organismos simbiontes. No substrato do poliqueto, além do alto hidrodinamismo local, o espaço disponível na colônia parece ser mais restrito e pode limitar o tamanho de seus habitantes. Os animais simbiontes do briozoário parecem não serem influenciados por fatores externos à colônia, entretanto o mesmo não foi observado nos simbiontes do poliqueto. Tais diferenças reprodutivas refletem o tipo de substrato ocupado, evidenciando a plasticidade fenotípica da espécie para uma melhor adaptação local. 
The crustaceans are the most diverse of the marine invertebrates and many of them tend to associate with other organisms where they can find shelter, food supply and a safe place to reproduce. Reproductive traits as fecundity, egg size and reproductive output $(\mathrm{RO})$ are the most important aspects to understand the species life history. This study aimed to investigate the reproductive traits in relation to the substrate that the organisms live. The studied species used as model was the porcellanid crab Pachycheles monilifer that was collected in two different substrates, one of them is the bryozoan Schizoporella errata at the Itaguá beach and the other is the polychaete Phragmatopoma caudata at Grande beach, both are located in Ubatuba, northern coast of São Paulo. Only the initial stage of eggs was used to estimate the crab fecundity and RO. The eggs were counted and measured in a stereomicroscope. To obtain the RO the female and the egg mass dry weight, which were previously dried in an oven, were used. Besides the reproductive aspects, the genetic distance between the organisms was valued with partial sequences of the mitochondrial genes $16 \mathrm{~S}$ and $\mathrm{CO}$. The estimate of the intra and interspecific genetic variation and the possibility of gene flow between the individuals from the beaches in SP were analyzed too. Therefore, with all these analyses it was possible to confirm that the species is valid and that there is gene flow among the populations. The low genetic divergence allowed us to conclude that the different reproductive traits found among the populations were due to the different substrates that the organisms inhabit. The bryozoan symbionts are larger than the polychaete symbionts as well as the females' fecundity and the $\mathrm{RO}$, but there is no difference in egg size. In the bryozoan substrate it seems like the physical stress is smaller than in polychaete and it promotes a more stable habitat for the crabs reproduce. In the polychaete substrate, beyond the high hydrodynamic location, the available space in the colony appears to be narrower, which could limit the size of its inhabitants. The bryozoan symbionts do not seem to be influenced by the external factors of the colony, though the same was not observed in the polychaete colony. Such differences in reproduction reflect the kind of substrate inhabited, highlighting the phenotypic plasticity of the species to a local better adaptation. 


\section{Simbiose e Potencial Reprodutivo}

No ambiente marinho é comum encontrar organismos vivendo em associação com uma ampla gama de macroinvertebrados, sendo que essa relação de simbiose pode ocorrer entre organismos aparentados (Botaña \& Thiel, 2001) ou distantes (Weis et al., 2001). O termo 'simbiose' aqui utilizado se refere a diferentes organismos que vivem em associação (Vermeij, 1983). A relação de simbiose é caracterizada em termos de custos e benefícios para ambos os organismos envolvidos, pelo número de espécies hospedeiras que são habitadas pelos simbiontes e o grau de dependência da relação. Essa interação é vantajosa sempre que os benefícios excedem os custos derivados da associação ou quando a rede de benefícios vivenciada por um dos organismos excede os benefícios do modo de vida livre (Roughgarden \& Pacala, 1982). Alguns estudos têm demonstrado que um dos benefícios mais importantes derivado de organismos simbiontes é a proteção contra predadores (Bloom, 1975; Vance, 1978). Assim, a pressão da predação é considerada uma das forças evolucionárias mais importantes que explicam a relação de simbiose entre os organismos (Vermeij, 1983).

Os crustáceos estão entre os invertebrados marinhos mais diversos e que, apesar de sua capacidade de natação, tendem a se associar com outros organismos (Mantelatto \& Souza-Carrey, 1998). Muitos desenvolveram um modo de vida simbionte, apresentando uma ampla gama de hospedeiros com complexas relações interespecíficas, sendo essa relação uma importante adaptação ambiental (Ross, 1983; Thiel \& Baeza, 2001). Muitas espécies de siris, caranguejos, anomuros, isópodes e anfípodes desenvolveram certo grau de dependência com outros macroinvertebrados, como corais, moluscos, equinodermos, hidrozoários, poliquetos, dentre outros (Thiel \& Baeza, 2001). Esses hospedeiros possuem diversas características que os diferencia grandemente entre si com relação à biologia e ecologia, envolvendo plano corporal, morfologia, abundância, distribuição e habitat (Baeza, 2008).

Nessa relação de simbiose, um microhabitat pode ser construído a partir do agrupamento das espécies, o que permite aos simbiontes encontrar um ambiente que oferece proteção contra predadores, oferta de alimento e um lugar seguro para reprodução e desenvolvimento dos organismos imaturos (Shuster, 1987; Stebbins, 1989; Stimson, 1990; Mantelatto \& Souza-Carrey, 1998).

Muitos organismos simbiontes vivem em agregações em seus hospedeiros e, geralmente, estão presentes organismos de ambos os sexos. Por outro lado, alguns 
vivem em pares heterossexuais (Knowlton, 1980; Patton et al., 1985; Vannini, 1985; Baeza \& Thiel, 2000), o que diminui o risco de predação, pois não é necessário deixar o hospedeiro a procura de um parceiro sexual (Thiel et al., 2003), entretanto também podem viver em poligamia (Shuster, 1987).

Para a compreensão da história natural e a garantia de manutenção de uma população há dois aspectos reprodutivos, dentre outros, que são essenciais: a produção de ovos e a fecundidade (Caddy, 1989). Nos Decapoda, a fecundidade é caracterizada pelo número de embriões em estágio inicial de desenvolvimento, produzidos pela fêmea a cada desova (Mantelatto \& Fransozo, 1997). O número de embriões produzidos tem influência direta do tamanho da fêmea, pois a carapaça é um fator limitante do espaço físico da massa de embriões no abdômen e o espaço cefalotorácico para o desenvolvimento dos ovários (Bauer, 1991; Reid \& Corey, 1991; Mantelatto \& Fransozo, 1997).

Assim como a fecundidade, o tamanho dos embriões também é um parâmetro importante na história de vida de uma espécie. Geralmente o tamanho do embrião é um caráter espécie-específico, embora não seja estritamente determinado por fatores genéticos, mas também pelas pressões ambientais, as quais podem influenciar o investimento reprodutivo e o desenvolvimento das larvas (Bauer, 1991; Laptikhovsky, 2005).

A variação do tamanho dos embriões tem gerado grande discussão, além de propostas de teorias, que se diferenciam em relação ao fator causador de tal diferenciação. A disponibilidade de nutrientes, latitude, temperatura e estratégias de sobrevivência larval são os principais fatores citados como responsáveis pela diferenciação do tamanho dos embriões entre espécies e populações (Rass, 1941; 1986; Thorson, 1936; 1946; 1950; Alekseev, 1981). Assim, o tamanho dos embriões pode ser um indicativo de padrões e estratégias evolutivas de cada população (Laptikhovsky, 2005).

$\mathrm{Na}$ tentativa de avaliar a energia que a fêmea destina à reprodução, dois critérios têm sido citados na literatura: o esforço reprodutivo (em inglês reproductive effort, RE) e o investimento reprodutivo (em inglês reproductive output, $\mathrm{RO}$ ). O RE consiste na energia que o organismo é capaz de assimilar e investir na reprodução, envolvendo parâmetros complexos como taxas metabólicas (assimilação de nutrientes e oxigênio), atividades comportamentais relacionadas à reprodução e energia alocada para carregar e proteger os embriões (Tinkle \& Hadley 1975; Hines 1982; Clarke, 1987) e envolve um trabalho intenso no estudo fisiológico do animal. Devido a tal dificuldade, o critério mais comumente utilizado entre os Decapoda é o investimento reprodutivo (RO). (Hines, 1992). Segundo Clarke et al. (1991), esse energia é 
calculada por meio da relação entre a biomassa dos embriões e biomassa das fêmeas.

Segundo Hartnoll (2006), a variação do investimento reprodutivo (\%) das fêmeas de diferentes espécies de caranguejos de vida livre varia de 3,2 a 18,8\% e dentre espécies de caranguejos pinoterídeos comensais a variação é de 59 a 96,7\%. Diante de tal diferença, o estudo sobre o investimento reprodutivo em espécies simbiontes constitui uma janela promissora a ser avaliada a fim de investigar a existência de uma relação estreita com o modo de vida.

Os diferentes padrões de associação entre diversos organismos sugerem que a ecologia, morfologia, complexidade e abundância do hospedeiro/substrato interferem no comportamento social do simbionte (Thiel \& Baeza, 2001), além de possivelmente influenciar na estrutura do sistema reprodutivo. Numa população pode haver diferenças com relação aos aspectos reprodutivos, podendo ser resultado de variações genéticas locais, que sofrem efeito da seleção natural do ambiente onde vivem e/ou reflexo da plasticidade fenotípica determinada pelo ambiente (Via \& Lande, 1985).

\section{Crustáceo Decapoda como modelo de estudo}

Os crustáceos Decapoda constituem em um ótimo modelo de estudo, já que a maioria de seus representantes pode ser facilmente coletada, além de serem abundantes e de ampla distribuição e com inúmeros tipos de associação.

Dentre os Decapoda marinhos, os caranguejos da família Porcellanidae Haworth, 1825 Infraordem Anomura Macleay, 1838 estão entre os crustáceos mais diversos e abundantes de águas temperadas e tropicais (Williams, 1984). Os porcelanídeos são caranguejos de pequeno porte que se assemelham morfologicamente aos caranguejos verdadeiros da Infraordem Brachyura Linnaeus, 1758, entretanto possuem o último par de pereópodos reduzido e, frequentemente, localizado abaixo da carapaça (Rodríguez et al., 2005; Osawa \& McLaughlin, 2010). Muitos são de vida livre, encontrados em substratos de natureza consolidada como as rochas e fendas em costões intermareais (Scelzo, 1985; Stevcic, 1988). Entretanto, algumas espécies desenvolveram forte relação com outros organismos, sendo encontrados em associação com invertebrados coloniais sésseis, como colônias de briozoários e poliquetos sabelídeos (Gore et al., 1978), ambos formadores de substratos biológicos, e também com esponjas, corais, anêmonas e ouriços (Baeza \& Thiel, 2000). Podem também ser encontrados, embora sejam poucas espécies, em 
substratos lamosos como manguezais (e.g. Petrolisthes armatus) (Miranda \& Mantelatto, 2009, 2010a e b) e áreas estuarinas (Werding et al., 2003). Os caranguejos porcelanídeos comensais, comparados a outros decápodes simbiontes, mostram baixa especificidade para escolha do hospedeiro simbionte, habitando assim, uma ampla gama de substratos (Baeza \& Stotz, 2001). Entretanto, Gore et al. (1978) correlacionou a distribuição e ocorrência do porcelanídeo, Pachycheles monilifer, com a de um poliqueto sabelerídeo na costa da Flórida, EUA, mostrando a dependência do caranguejo em relação à distribuição do poliqueto.

Atualmente, estão descritas 277 espécies de porcelanídeos habitando todo o Atlântico Ocidental e o Pacífico Oriental, sendo que destas, sete espécies do gênero Pachycheles estão distribuídas ao longo da costa do litoral brasileiro (Ferreira \& Melo, 2010; Osawa \& Mclaughlin, 2010). Em particular, o caranguejo porcelanídeo Pachycheles monilifer (Dana, 1852) está distribuído na costa do Atlântico Ocidental, da Florida (EUA) até o Brasil (do Pará à Santa Catarina) e também pode ser encontrado no Pacífico Oriental (Equador e Peru) (Veloso \& Melo, 1993; Rodríguez et al., 2005).

Assim, Pachycheles monilifer foi utilizado como modelo de estudo, o qual é bastante comum no litoral norte de São Paulo e apresenta modo de vida simbionte com o briozoário Schizoporella errata (Walters, 1878) e com o poliqueto Phragmatopoma caudata (Kröyer, 1856) (Gore et al., 1978; Mantelatto \& SouzaCarrey, 1998; Hattori \& Pinheiro, 2001). A espécie em estudo é um caranguejo de pequeno porte que se alimenta por filtração da água utilizando o terceiro maxilípodo na captura de partículas e plâncton em suspensão na coluna d'água (Gore et al., 1978). Pode ser facilmente diferenciada das outras espécies do gênero devido à disposição e pubescência dos tubérculos característicos presente nos quelípodos (figura 1) (Haig, 1960; Gore \& Abele, 1976).

O briozoário do gênero Schizoporella (Hincks, 1877) pode ser encontrado em áreas de alto hidrodinamismo, entretanto habita preferencialmente águas rasas e calmas com alta concentração de matéria orgânica (Gusso-Chimenz \& RivosecchiTaramelli, 1972 in Cocito et al., 2000). A colônia somente resulta numa forma estrutural complexa com ramos delgados e ramificados, a qual permite a associação de diversos organismos, quando localizada em áreas abrigadas com baixo hidrodinamismo (Cocito et al., 2000). Vogel (1988) relacionou a forma laminar com ambientes mais expostos, podendo ser um indicativo de que o briozoário é incapaz de sustentar essa formação complexa onde há forte impacto de ondas (Cocito et al., 2000). Essa complexa forma estrutural possibilita que organismos sedentários e móveis encontrem abrigo entre e dentro dos ramos do briozoário. O crescimento e a estruturação em ramos da colônia dependem em partes da presença destes 
organismos simbiontes, pois funcionam como moldes para sua conformação (Cocito et al., 2000).

Especificamente, a espécie Schizoporella errata possui uma fauna associada de invertebrados bastante diversificada, como esponjas, cnidários, tunicados, sendo que os organismos mais abundantes são os crustáceos decápodes (Morgado, 1980; Mantelatto \& Souza-Carrey, 1998). Segundo os últimos autores, essa colônia de briozoário representa um sítio potencial para o desenvolvimento reprodutivo para espécies de Anomura, considerando a grande diversidade de fêmeas ovígeras, principalmente do caranguejo porcelanídeo Pachycheles monilifer, encontradas nesse substrato.

O poliqueto sabelerídeo Phragmatopoma caudata, tem uma habilidade peculiar de formar extensos bancos de areia em zonas de arrebentação de ondas, principalmente em ambientes expostos ao mar aberto (Gore et al., 1978). Estes bancos de areia frequentemente oferecem refúgio e oferta de alimento para diversos organismos (Wilson, 1979), sendo comumente encontrada grande diversidade de organismos associados, como moluscos, esponjas, briozoários, antozoários e, principalmente, crustáceos decápodes, incluindo o porcelanídeo $P$. molinifer (Gore et al., 1978; Pinheiro \& Fransozo, 1995; Bosa \& Masunari, 2002).

Os bancos de areia formados pelo poliqueto representam grande importância na sobrevivência dos organismos simbiontes, pois essa formação permite a redução do impacto das ondas, além de propiciar a drenagem da água mais eficiente pela colônia (Narchi \& Rodrigues, 1965). Estudos prévios evidenciaram a importância desse tipo de substrato biológico para o desenvolvimento de várias espécies de crustáceos Decapoda, entre eles do porcelanídeo Pachycheles monilifer, que foi a espécie mais abundante em colônias da Florida, EUA e em Ubatuba, Brasil (Gore et al., 1978; Pinheiro et al., 1997; Micheletti-Flores \& Negreiros-Fransozo, 1999).

Ambos os substratos biológicos são previamente reconhecidos como habitats disponíveis e de grande potencial para o desenvolvimento biológico e reprodutivo da espécie Pachcyheles monilifer (Gore et al., 1978; Pinheiro \& Fransozo, 1995; Mantelatto \& Souza-Carrey 1998; Cocito et al., 2000; Hattori \& Pinheiro, 2001).

Estudos sobre fecundidade e RO têm sido realizados com organismos que habitam diferentes localidades e, consequentemente, diferentes latitudes (Jones \& Simons, 1983; Berkenbusch \& Rowden, 2000; Hernáez-Bové \& Pinheiro, 2001; Lardies \& Whertmann, 2001; Lardies \& Castilla, 2001; Terossi et al., 2010). Entretanto, nenhum trabalho visou investigar a possibilidade de influência do substrato nos aspectos reprodutivos. 


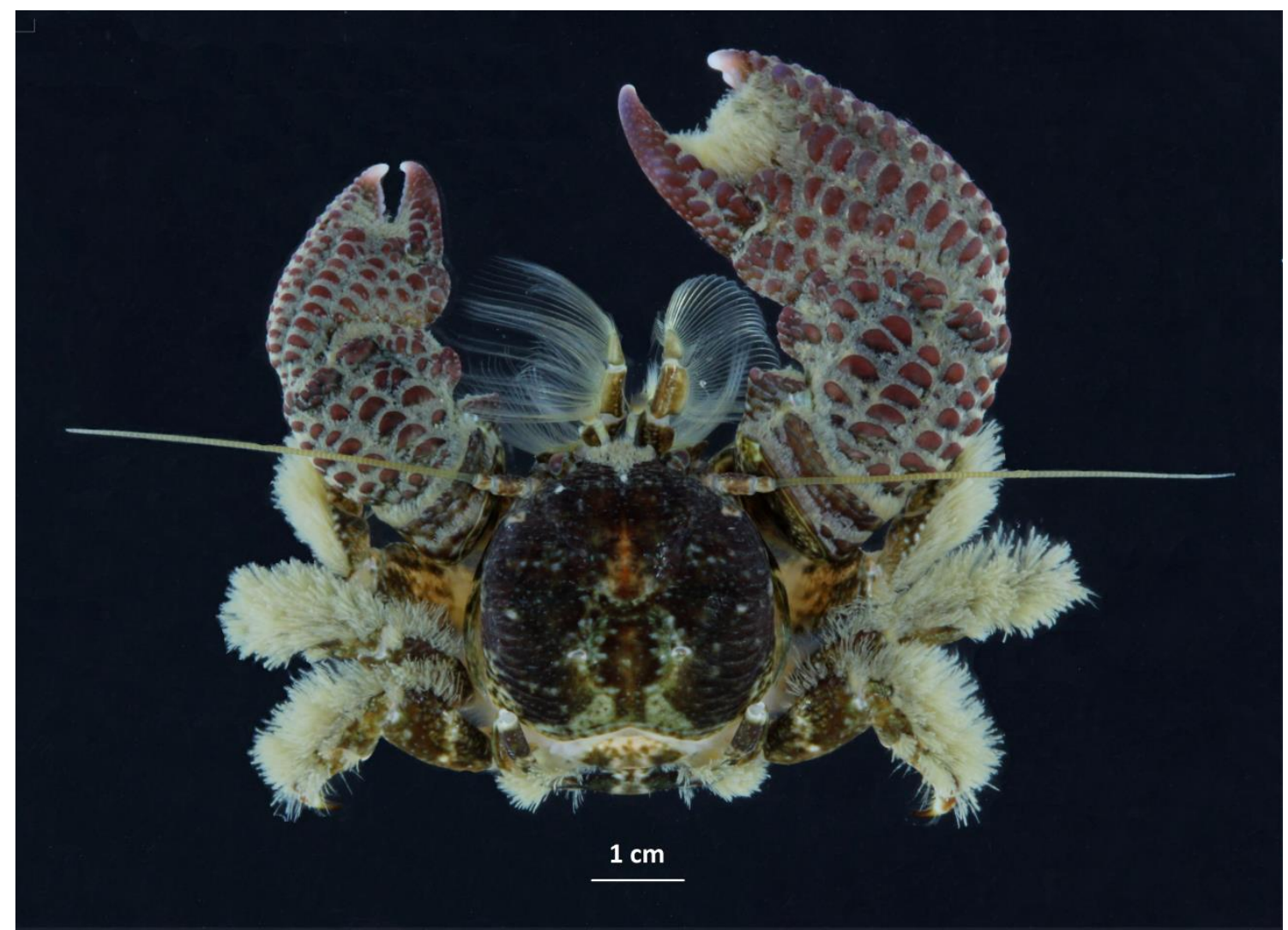

Figura 1: Vista dorsal de um exemplar do porcelanídeo simbionte Pachycheles monilifer coletado no píer do Itaguá, Ubatuba (Coleção de Crustáceos do Departamento de Biologia - CCDB 4300).

\section{Variabilidade genética}

Dentre os Decapoda, e também outros grupos que apresentam relações duvidosas, estão sendo utilizados genes mitocondriais para elucidar problemas filogenéticos e taxonômicos, os quais a morfologia por si só muitas vezes não é capaz de solucionar (Knowlton et al., 1993; Knowlton, 2000). Assim como a morfologia, a sistemática molecular utiliza métodos comparativos, que envolvem a comparação direta ou indiretamente da sequência de ácidos nucleicos e proteínas, evidenciando a importância do uso de técnicas moleculares também em estudos de genética de populações (Avise, 2004).

O uso do DNAmt tem sido promovido desde a década de 70 como uma poderosa ferramenta para estudos evolutivos em animais. O genoma mitocondrial na maioria dos animais é constituído por uma molécula de DNA pequena e circular, de genoma conservado e estrutura mais simples que o nuclear (Moritz et al., 1987). 
Segundo Schubart (2009), os genes mitocondriais são mais comumente utilizados do que genes nucleares, devido à maior quantidade de genoma mitocondrial presente nas células, podendo ser amplificado mais facilmente. Entretanto, a preferência de sua aplicação é devida, principalmente, às suas características estruturais, como apresentar maior taxa de mutação, permitindo o acúmulo do sinal filogenético em menor tempo que o gene nuclear e, também, a ausência de íntrons, o que torna o DNA quase que inteiramente informativo. Sua interpretação pode ser mais simplificada por não sofrer recombinação e ser herdado de forma uniparental (Schubart, 2009).

O DNAmt tem se mostrado um excelente marcador genético em estudos intraespecíficos e populacionais, já que apresenta considerável variação em indivíduos pertencentes à mesma população ou à populações distintas. Assim, análises do genoma mitocondrial têm sido úteis no sentido de evidenciar padrões estruturais em populações separadas geograficamente (Avise et al., 1987).

Dois genes mitocondriais comumente utilizados são o 16S e COI. O gene $16 S$ é um gene estrutural não-codificante, o qual tem se mostrado eficiente tanto em estudos filogenéticos, como em estudos populacionais (Schubart et al., 2000; Mantelatto et al., 2006; Robles et al., 2007). Esse gene possui regiões variáveis e outras mais conservadas, podendo ser umas das causas prováveis de seu uso global (Schubart et al., 2000). O gene COI é codificador de proteína e tem se mostrado mais eficiente em estudos populacionais por ser menos conservado e apresentar maior taxa de divergência em suas sequências do que o gene 16S (Daniels, 2003; Harrison, 2004; Francisco \& Galetti Junior, 2005; Liu et al., 2007; Pileggi \& Mantelatto, 2010; Vergamini et al., 2011).

Uma espécie pode apresentar padrões genéticos e estruturais distintos quando encontrada em ambientes heterogêneos ou isolada geograficamente (Baker et al., 2008). Acreditando que o fitness reprodutivo tenha forte ligação com o tipo de substrato habitado, deve-se considerar a possibilidade de que espécies habitantes de ambientes isolados e com possível ausência de fluxo gênico entre as duas populações desenvolvam diferentes padrões de reprodução. O termo população utilizado nesse trabalho refere-se a grupos de indivíduos pertencentes a mesma espécie que habitam um determinado ambiente. 
Objetivos 
Este trabalho visou comparar o potencial reprodutivo do porcelanídeo simbionte Pachycheles monilifer habitante de dois substratos biológicos diferentes, o briozoário Schizoporella errata e o poliqueto Phragmatopoma caudata, a fim de avaliar a hipótese de influência do tipo de substrato no processo de fecundidade e investimento reprodutivo, além de comparar a estrutura genética das populações estudadas por meio de dados moleculares. 


\section{Material e Métodos}




\section{Coletas e processamento dos dados}

Como o objetivo principal deste trabalho necessita da obtenção de fêmeas ovígeras as coletas destas não foram realizadas periodicamente, mas se concentraram, principalmente, nos meses reconhecidamente de maior ocorrência de fêmeas ovígeras (meses de verão). Entretanto, foram realizadas coletas nas estações seca (abril a setembro) e chuvosa (outubro a março) em 2011 e em janeiro de 2012, a fim de obter uma amostragem fiel da população.

As coletas foram realizadas em duas praias de Ubatuba (litoral norte de São Paulo) com diferentes características de hidrodinamismo e perfil de substrato. A praia

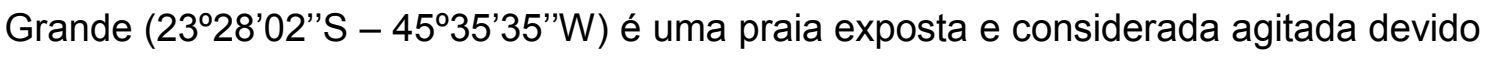
ao constante impacto das ondas sob o costão rochoso, onde estão localizados os bancos de areia do poliqueto Phragmatopoma caudata. O píer do Itaguá (2327'05'S $45^{\circ} 02^{\prime} 48^{\prime \prime} \mathrm{W}$ ) é um local abrigado, situado dentro de uma baía, com movimento de ondas moderados, onde se encontram alojadas as colônias do briozoário Schizoporella errata (Figura 2).

O litoral norte do estado de São Paulo, em particular a região de Ubatuba, é de extrema importância para o estudo de crustáceos, mostrando um grande potencial biológico de diversidade de espécies (Fransozo et al., 1998; Mantelatto \& Fransozo, 2000).

Para a coleta dos caranguejos associados às colônias do briozoário Schizoporella errata no píer do Itaguá foram realizados mergulhos autônomos em profundidade de 1 a 4 metros, onde as colônias do briozoário foram deslocadas do substrato e alocadas em sacos plásticos para posterior triagem. Na praia Grande durante o período de maré baixa, os exemplares associados ao poliqueto foram manualmente coletados utilizando uma faca para abrir as cavidades das colônias. $O$ tempo de coleta nas duas praias não foi padronizado, devido às diferentes dificuldades encontradas em cada ambiente. Estas foram desenvolvidas visando a obtenção do material alvo para atender os objetivos do trabalho, i. e., obtenção de fêmeas ovígeras. As fêmeas ovígeras foram alocadas individualmente em eppendorfs para evitar a perda de embriões. 

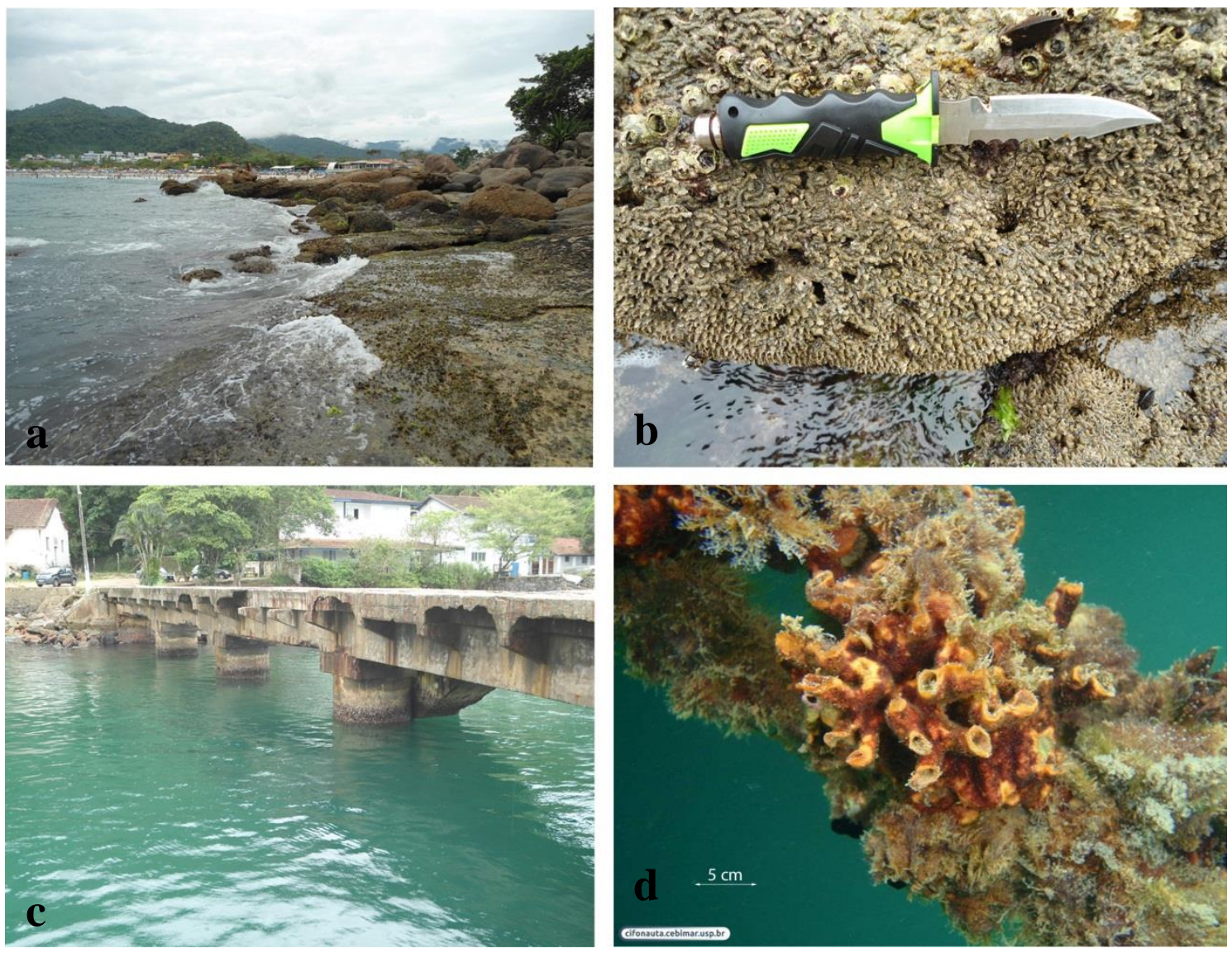

Figura 2: llustração dos locais em Ubatuba onde foram coletados os exemplares de Pachycheles monilifer e seus respectivos substratos; a. praia Grande; b. substrato do poliqueto Phragmatopoma caudata; c. píer do Itaguá; d. substrato do briozoário Schizoporella errata (modificado de cifonauta.cebimar.usp.br, foto original de Alvaro E. Migoto).

Após as coletas, os animais foram fixados em álcool $80 \%$ e depositados na Coleção de Crustáceos do Departamento de Biologia (CCDB) do Laboratório de Bioecologia e Sistemática de Crustáceos (LBSC) da Faculdade de Filosofia, Ciências e Letras de Ribeirão Preto, Universidade de São Paulo (FFCLRP/USP), sob as numerações 402, 413, 423, 431, 3297, 3298, 4154, 4300 e 4301.

Os animais coletados foram averiguados quanto ao sexo, sendo as fêmeas identificadas pela presença do gonóporo no terceiro par de pereópodos e pela presença de pleópodos no abdômen e os machos, pela ausência de pleópodos (Melo, 1999; Ferreira, 2010; Silva, 2011). Os indivíduos foram mensurados quanto ao comprimento da carapaça ( $\mathrm{CC}$ em $\mathrm{mm}$ ), utilizando-se um paquímetro digital com precisão de $0,01 \mu \mathrm{m}$, consistindo da margem anterior do rostro até a margem posterior da carapaça (figura 3). Nas fêmeas ovígeras tais medidas foram relacionadas com fecundidade, volume dos ovos e o investimento reprodutivo. Os indivíduos foram 
divididos em classes de tamanho utilizando-se a fórmula amplitude da classe $=$ desvio padrão/2.

Os exemplares que apresentaram comprimento de carapaça menor que a menor fêmea ovígera foram considerados juvenis para ambos os sexos (Ahmed \& Mustaquim, 1974; Oliveira \& Masunari, 1995) e foram chamados de recrutas os caranguejos pertencentes a primeira classe de tamanho (Pardo et al., 2007).

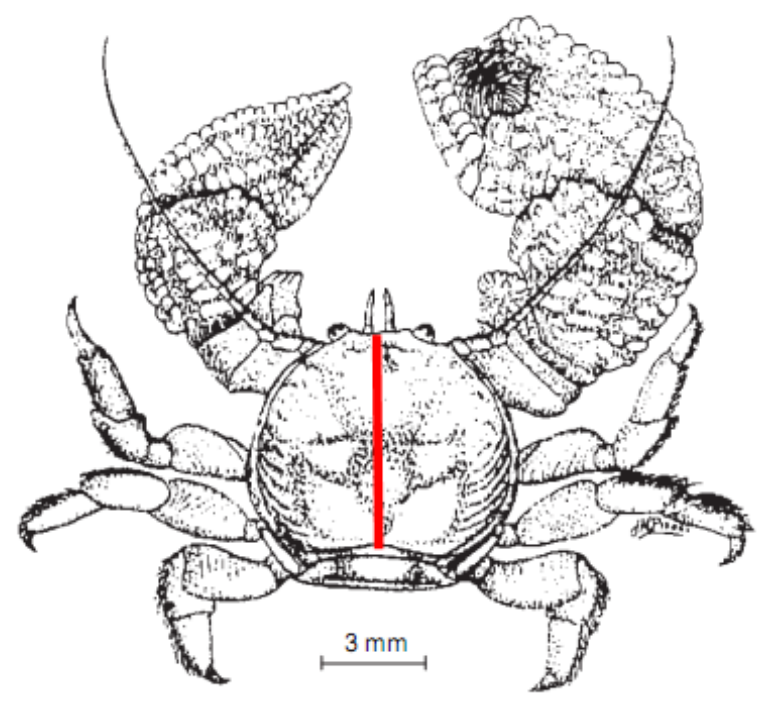

Figura 3: Vista dorsal do caranguejo porcelanídeo Pachycheles monilifer com a indicação da medida da carapaça (modificado de Micheletti-Flores \& NegreirosFransozo, 1999).

\section{Fecundidade e Volume dos embriões}

Os embriões aderidos aos pleópodos das fêmeas foram cuidadosamente removidos com uma pinça, colocados sobre uma placa de acrílico quadriculada e contados sob estereomicroscópio com um contador manual. Os embriões foram classificados em relação ao estágio de desenvolvimento segundo a metodologia de Lardies \& Wehrtmann (1996) e Mantelatto \& Garcia (1999), modificado de Boolootian et al. (1959) que propuseram 3 estágios baseando-se na quantidade de vitelo e no surgimento das estruturas típicas da larva no embrião:

>Inicial: embrião com formato arredondado, vitelo uniforme e sem mancha ocular visível;

>Intermediário: embrião com formato ovóide, mancha ocular alargada e pouco visível; 
>Final: embrião ovóide, olhos visíveis, bem desenvolvidos e intensamente pigmentados e abdômen livre.

Para análises de fecundidade foram selecionadas apenas as fêmeas que apresentaram embriões em estágio inicial de desenvolvimento, pois já foi reportado na literatura que em decápodes há perda de embriões durante o período de desenvolvimento (Kuris, 1991). Optou-se por utilizar apenas as fêmeas que apresentaram fecundidade igual ou maior a cinco embriões, pois um valor inferior pode não representar a fecundidade da fêmea (Terossi et al., 2010), podendo ser consequência de alguma variável exógena, por exemplo, perda por predação, parasitismo, estresse mecânico ou mesmo pelo aumento dos embriões durante o desenvolvimento (Balasundaram \& Pandian, 1982; Kuris, 1991; Oh \& Hartnoll, 1999; Oh \& Hartnoll, 2004; Figueiredo et al., 2008). Para a obtenção do tamanho dos embriões (maior e menor diâmetro) foram selecionados aleatoriamente 10 embriões de cada fêmea, os quais tiveram suas medidas realizadas com estereomicroscópio com câmara clara acoplada, assim como seu volume $\left(\mathrm{mm}^{3}\right)$, que foi calculado a partir da fórmula $\mathrm{VO}=\left(\pi\left(e_{1}\right)^{2} \cdot e_{2}\right) / 6$, onde $e_{1}$ representa o valor do menor eixo e $e_{2} 0$ valor do maior eixo sugerida por Turner \& Lawrence (1979).

\section{Investimento Reprodutivo (RO)}

Para a análise do investimento reprodutivo foram obtidos os pesos seco e úmido das fêmeas e da massa de embriões, para comparação de metodologias. Para a obtenção do peso úmido utilizou-se papel toalha de alta absorção a fim de retirar o máximo possível de água das fêmeas e da massa de embriões. Após adquirir o peso úmido, as fêmeas e os embriões foram submetidos à estufa a uma temperatura de $50^{\circ} \mathrm{C}$ durante o período de 48 e 24 horas, respectivamente, segundo a metodologia desenvolvida por Clarke et al. (1991). As fêmeas e os ovos foram pesados numa balança eletrônica de precisão de $0,0001 \mathrm{~g}$. Para a efetiva medição do investimento reprodutivo $(\mathrm{RO})$ de cada fêmea, foi utilizada a fórmula descrita por Clarke et al. (1991), onde RO = peso total dos embriões/peso total da fêmea (sem a massa de embriões). Para o cálculo de investimento reprodutivo (RO) algumas fêmeas foram excluídas dessa análise, pois a balança não detectou o baixo peso de algumas massas de embriões. 


\section{Análises estatísticas}

As amostras foram testadas para normalidade utilizando 0 teste de Kolmogorov-Smirnov no programa SigmaStat $\AA^{\circ}$ 2.0. No caso de testes paramétricos foi realizado teste t para comparar o tamanho das fêmeas ovígeras. Como a distribuição das populações não passou no teste de normalidade, foi utilizado o teste não paramétrico de Mann-Whitney Rank Sum para comparar o tamanho das duas populações, das fêmeas ovígeras e não ovígeras e entre machos e fêmeas. Foi utilizado o teste $x 2$ para a razão sexual entre machos e fêmeas. A correlação de Pearson foi utilizada para analisar a correlação entre CC e fecundidade; CC e RO; CC e volume dos embriões; fecundidade e RO. O volume dos embriões dos dois grupos de fêmeas foi examinado com o teste não paramétrico One Way Analysis of Variance on Ranks (ANOVA), assim como para o aumento de volume entre os estágio embrionários.

Foi utilizado o teste One Way Analysis of Variance (ANOVA) do tipo III para analisar a relação entre: substrato, $\mathrm{CC}$ e fecundidade; substrato, $\mathrm{CC}$ e RO; estágio de desenvolvimento dos embriões, CC e número de embriões.

Devido ao baixo número de fêmeas que portavam embriões em estágio final de desenvolvimento embrionário em ambos os substratos ( $\mathrm{n}=2$ no substrato do poliqueto e $\mathrm{n}=4$, no substrato do briozoário), este foi calculado junto com o estágio intermediário, sendo assim para todos os cálculos foram considerados apenas dois estágios de desenvolvimento (inicial e intermediário/final).

Foi utilizado o teste não paramétrico para a comparação entre as metodologias para o cálculo de RO (pesos úmido e seco) One Way Analysis of Variance on Ranks, já que a distribuição não foi normal, com posterior teste de Dunn's.

\section{Obtenção dos dados moleculares}

Foi feita a extração do material genético de 23 indivíduos de Pachycheles monilifer, sendo que os testemunhos genéticos (vouchers) foram depositados na Coleção de Crustáceos CCDB/FFCLRP/USP e também foram utilizadas algumas sequências retiradas do banco de dados GenBank (tabela 1).

Foram utilizados os genes mitocondriais $16 \mathrm{~S}$ e $\mathrm{COI}$ (citocromo-oxidase I). Nas análises, como grupo externo para as sequências do gene 16S, utilizaram-se os 
porcelaníeos Pachycheles serratus, $P$. laevidactylus, $P$. ackleianus e $P$. spinidactylus, importadas do GenBank. Para o gene COI foram utilizadas apenas sequências geradas nesse trabalho.

O processo de extração do DNA e amplificação por técnicas de PCR (Polymerase Chain Reaction) foram realizados segundo o protocolo elaborado por Mantelatto et al., 2007; 2009a, b) com modificações em Pileggi \& Mantelatto (2010). A obtenção do DNA genômico foi através da extração de tecido muscular da parte interna ou regiões membranosas localizadas nas articulações dos quelípodos dos indivíduos selecionados.

Após a retirada do tecido, este permaneceu por 24 horas em banho seco a $55^{\circ} \mathrm{C}$ juntamente com $600 \mu \mathrm{L}$ lysis buffer e $200 \mu \mathrm{L}$ de proteinase $\mathrm{K}(500 \mu \mathrm{g} / \mathrm{mL})$. Após o período de incubação, as proteínas foram separadas com a adição de $200 \mu \mathrm{L}$ de $\mathrm{NH}_{4} \mathrm{Oac} 7,5 \mathrm{M}$ seguida de centrifugação a $14000 \mathrm{rpm}\left(18^{\circ} \mathrm{C}\right)$ por $10 \mathrm{~min}$. Adicionou-se $700 \mu \mathrm{L}$ de isopropanol para a precipitação do material genético restante da solução com posterior resfriamento e centrifugação. O 'pellet' resultante foi lavado com $15 \mu \mathrm{L}$ de etanol $70 \%$, secos a temperaturas de $30^{\circ} \mathrm{C}$ e ressuspendidos com $20 \mu \mathrm{L}$ de tampão TE.

Para amplificação da região do gene mitocondrial $16 \mathrm{~S}$ foram utilizados os primers H2 (5'-AGATAGAAACCAAAAACCTGG-3') e L2 (5'-TGCCTGTTTATCAAAAA CAT-3') (Palumbi \& Benzie, 1991) e para amplificar a região do gene COI, foram utilizados os primers COH6 (5'-TADACTTCDGGRTGDCCAAARAAYCA-3') e COL6b (5'-ACAAATCATAAAGATATYGG-3') (Schubart \& Huber, 2006). Os produtos do PCR foram obtidos em uma reação de volume total de $25 \mu$ l contendo 5,0 a $6,5 \mu \mathrm{L}$ de água

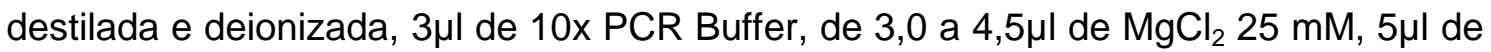
betaína (5M), $4 \mu \mathrm{L}$ de dNTPs, $1 \mu \mathrm{L}$ de cada primer, $1 \mu \mathrm{L}$ de Thermus aquaticus polimerase (Taq) e $1 \mu \mathrm{l}$ do DNA extraído. A concentração do DNA foi medida pelo NanoDrop dependendo dessa medida este foi previamente concentrado ou diluído.

A amplificação do DNA pela técnica de PCR foi realizada no termociclador Applied Biosystems Veriti 96 Well Thermal Cycler® com os seguintes ciclos termais, gene COI: desnaturação inicial por $2 \min$ a $94^{\circ} \mathrm{C}$; desnaturação, anelamento e extensão por 35 ciclos: 45 segundos a $94^{\circ} \mathrm{C}, 45$ segundos a $42^{\circ} \mathrm{C}, 1,5 \min$ a $72^{\circ} \mathrm{C}$; extensão final por 10 min a $72^{\circ} \mathrm{C}$; para o gene 16S: desnaturação inicial por 5 min a $95^{\circ} \mathrm{C}$; desnaturação, anelamento e extensão por 40 ciclos: 45 segundos a $95^{\circ} \mathrm{C}, 45$ segundos a $48^{\circ} \mathrm{C}, 1 \mathrm{~min}$ a $72^{\circ} \mathrm{C}$; extensão final por $3 \mathrm{~min}$ a $72^{\circ} \mathrm{C}$. Os resultados dos PCRs foram observados em eletroforese com gel de agarose $1 \%$ e fotografados com uma câmera digital C-7070 da Olimpus em um transiluminador UV Transilluminator 
M20 da UVP. Os produtos do PCR foram purificados utilizando o protocolo do kit Sure Clean®.

Utilizou-se, para a reação de sequenciamento, um volume total de $20 \mu \mathrm{L}$ contendo $8 \mu \mathrm{L}$ de água destilada e deionizada, $6 \mu \mathrm{L}$ de $2.5 \mathrm{x}$ Big Dye ${ }^{\circledR}$ Terminator Sequencing Buffer, $2 \mu \mathrm{L}$ de Big Dye ${ }^{\circledR}$ Terminator Mix (Applied Biosystems) (deoxinucleotídeos, dideoxinucleotídeos fluorescentes e Taq DNA polimerase), $2 \mu \mathrm{L}$ primer $(10 \mu \mathrm{M})$ e $2 \mu \mathrm{L}$ do produto do PCR previamente purificado. O PCR de sequenciamento foi realizado no termociclador Applied Biosystems Veriti 96 Well Thermal Cycler $\AA$, com o seguinte ciclo: desnaturação inicial por 2 minutos a $96^{\circ} \mathrm{C}$; anelamento por 35 ciclos ( 45 segundos a $96^{\circ} \mathrm{C}$; 30 segundos a $50^{\circ} \mathrm{C} ; 4$ minutos a $60^{\circ} \mathrm{C}$ ) e posteriormente purificado por um processo de precipitação.

As placas foram então colocadas no sequenciador automatizado ABI 3100 Genetic Analyzer ${ }^{\circledR}$ (Applied Biosystems, automated sequencer) do Departamento de Tecnologia da Faculdade de Ciências Agrárias e Veterinárias de Jaboticabal (FCAV) da Universidade Estadual Paulista "Júlio de Mesquita Filho" (UNESP). As sequências nucleotídicas foram editadas no BIOEDIT e alinhadas no programa Clustal W (Thompson et al., 1994, implementado no BIOEDIT).

As sequências foram alinhadas para as análises de distância no programa BioEdit 7.0.9.0 com parâmetros predefinidos no programa Clustal W (Thompson et al., 1994). Os fragmentos de DNA obtidos foram submetidos ao alinhamento no sistema BLAST para comparação com 0 banco de dados NCBI (http://blast.ncbi.ncbi.nlm.nih.gov/blast.cgi), sendo assim possível a confirmação de sua identidade. Todas as sequências obtidas foram depositadas no Genbank.

As análises de distância genética foram realizadas a partir de sequências parciais obtidas dos dois marcadores (16S e COI mtDNA). Para ambos os genes foram construídas matrizes divergência genética não corrigida $p$ no programa MEGA 5.0. (Tamura et al., 2011). Os dados de ambas as matrizes foram utilizados para construção de uma árvore pelo método de Neighbor-Joining também utilizando o programa MEGA 5.0. A consistência das topologias foi mensurada pelo método de bootstrap (Felsenstein, 1985), com 1000 réplicas, sendo que apenas os valores de confiança acima de $50 \%$ foram apresentados.

Foi analisada a estrutura e variabilidade genética a partir de sequências parciais do gene $\mathrm{COI}$ de indivíduos de $P$. monilifer provenientes de várias praias do litoral paulista. O número de haplótipos foi calculado no programa DnaSP versão 4.10.9 (Rozas \& Rozas, 1999). A diversidade de nucleotídeos e haplótipos foram estimadas para cada praia usando o programa Arlequin versão 3.1 (Excoffier et al., 2005). As redes de haplótipos foram construídas pelo método estatístico de 
parcimônia no TCS versão 1.21 (Clement et al., 2000) e pelo método Median-Joining no Network (Bandelt et al., 1999) com os dados previamente preparados no DnaSp.

Séries de análises de variação molecular foram computadas no Arlequin (AMOVA) (Excoffier et al., 2005) para examinar a distribuição da variação genética. Essas foram processadas baseadas na frequência de haplótipos sem estrutura somente entre populações da praia Grande e do Itaguá, visto que das outras localidades foi obtida apenas uma sequência de cada. Foi testada a significância dos resultados pelo procedimento de permutação não paramétrico (Excoffier et al., 2005), incorporando 1000 permutações. 
Tabela 1: Relação dos espécimes que foram utilizados nas análises moleculares com o respectivo número de indivíduos $(\mathrm{N})$ de cada praia, vouchers (coleção pertencente e número do catálogo), localidades e número de acesso no GenBank para cada sequência dos genes $16 \mathrm{~S}$ e COI. As sequência retiradas do GenBank encontram-se sinalizadas $\left.{ }^{*}\right)$. (CCDB - Coleção de Crustáceos do Departamento de Biologia; ULLZ University of Louisiana, Lafayette-USA).

\begin{tabular}{|c|c|c|c|c|c|}
\hline \multirow{2}{*}{ Espécime } & \multirow{2}{*}{$\mathbf{N}$} & \multirow{2}{*}{ Voucher } & \multirow{2}{*}{ Localidade } & \multicolumn{2}{|c|}{ Acesso GenBank } \\
\hline & & & & $16 S$ & $\mathrm{COI}$ \\
\hline \multirow{2}{*}{ Pachycheles monilifer } & \multirow{2}{*}{2} & \multirow{2}{*}{ CCDB 4154} & \multirow{2}{*}{$\begin{array}{l}\text { Píer do Itaguá, } \\
\text { Ubatuba }\end{array}$} & KC858098 & - \\
\hline & & & & KC858099 & - \\
\hline \multirow{4}{*}{ Pachycheles monilifer } & \multirow{4}{*}{4} & \multirow{4}{*}{ CCDB 4300} & \multirow{4}{*}{$\begin{array}{l}\text { Píer do Itaguá, } \\
\text { Ubatuba }\end{array}$} & KC858084 & KC858116 \\
\hline & & & & KC858085 & KC858115 \\
\hline & & & & KC858086 & - \\
\hline & & & & KC858087 & KC858114 \\
\hline \multirow[b]{2}{*}{ Pachycheles monilifer } & \multirow[b]{2}{*}{2} & \multirow[b]{2}{*}{ CCDB 423} & \multirow[b]{2}{*}{ Praia Grande, Ubatuba } & KC858091 & - \\
\hline & & & & KC858092 & KC858110 \\
\hline \multirow{3}{*}{ Pachycheles monilifer } & \multirow{3}{*}{3} & \multirow{3}{*}{ CCDB 431} & \multirow{3}{*}{ Praia Grande, Ubatuba } & KC858088 & KC858113 \\
\hline & & & & KC858089 & KC858112 \\
\hline & & & & KC858090 & KC858111 \\
\hline \multirow{2}{*}{ Pachycheles monilifer } & \multirow{2}{*}{2} & \multirow{2}{*}{ CCDB 3298} & \multirow{2}{*}{ Praia Grande, Ubatuba } & & KC858107 \\
\hline & & & & KC858101 & - \\
\hline \multirow[t]{2}{*}{ Pachycheles monilifer } & 1 & CCDB 2981 & $\begin{array}{l}\text { Praia do Lázaro, } \\
\text { Ubatuba }\end{array}$ & KC858094 & KC858109 \\
\hline & \multirow{3}{*}{3} & \multirow{3}{*}{ CCDB 634} & \multirow{3}{*}{ Ilha Anchieta, Ubatuba } & KC858095 & - \\
\hline \multirow[t]{2}{*}{ Pachycheles monilifer } & & & & KC858096 & - \\
\hline & & & & KC858097 & KC858108 \\
\hline Pachycheles monilifer & 1 & CCDB 4218 & $\begin{array}{c}\text { Ilha das Couves, } \\
\text { Ubatuba }\end{array}$ & KC858102 & - \\
\hline Pachycheles monilifer & 1 & CCDB 696 & $\begin{array}{c}\text { Ilha Prumirim, } \\
\text { Ubatuba }\end{array}$ & KC858105 & - \\
\hline Pachycheles monilifer & 1 & CCDB 2104 & $\begin{array}{c}\text { Praia do Segredo, São } \\
\text { Sebastião }\end{array}$ & - & KC858106 \\
\hline Pachycheles monilifer & 1 & CCDB 660 & $\begin{array}{c}\text { Praia Itararé, São } \\
\text { Vicente }\end{array}$ & KC858093 & - \\
\hline Pachycheles monilifer & 1 & CCDB 4213 & $\begin{array}{l}\text { Ilhabela, São } \\
\text { Sebastião }\end{array}$ & KC858104 & - \\
\hline Pachycheles monilifer & 1 & CCDB 1818 & $\begin{array}{l}\text { Isla Margarita, } \\
\text { Venezuela }\end{array}$ & KC858103 & - \\
\hline Pachycheles laevidactylus & 1 & CCDB 2379 & Praia Grande, Ubatuba & - & KC858117 \\
\hline Pachycheles serratus* & & CCDB 2765 & $\begin{array}{l}\text { Bocas del Toro, } \\
\text { Panamá }\end{array}$ & JF900732 & - \\
\hline Pachycheles spinidactylus* & & CCDB 2766 & $\begin{array}{c}\text { Montezuma, Costa } \\
\text { Rica }\end{array}$ & JF900734 & - \\
\hline Pachycheles ackleianus* & & ULLZ 4824 & Flórida, EUA & DQ865332 & - \\
\hline Pachycheles laevidactylus* & & CCDB 1936 & Itajaí, SC & JF900723 & - \\
\hline
\end{tabular}




\section{Resultados}




\section{Aspectos populacionais}

Durante o período de coleta foram obtidos 244 indivíduos associados ao briozoário Schizoporella errata no píer do Itaguá sendo $49,6 \%(n=121)$ de machos e $50,4 \%(n=123)$ fêmeas, dentre estas $58,5 \%(n=72)$ fêmeas ovígeras. A razão sexual foi de 0,9:1 (macho:fêmea), o que se assemelha ao equilíbrio esperado de 1:1 e não difere significativamente do esperado $\left(\chi^{2}=0,02\right)$. Associados ao poliqueto Phragmatopoma caudata na praia Grande foram coletados 245 indivíduos, dentre estes 55,9\% $(n=137)$ de machos e 44,1\% $(n=108)$ de fêmeas, apresentando 58,3\% ( $n=63$ ) de fêmeas ovígeras. A razão sexual entre os indivíduos associados ao poliqueto foi de $1,2: 1$, não apresentando diferença significativa do equilíbrio esperado $(\chi 2=3,43)$.

Apesar da distribuição de frequência de tamanho dos indivíduos ser simétrica (figura 4) de ambos os substratos apresentou uma distribuição não-normal. Os exemplares dos dois substratos foram divididos em 10 classes de tamanho, sendo que o menor coletado apresentou CC no valor de $1,77 \mathrm{~mm}$ e o maior $8,48 \mathrm{~mm}(4,3 \pm 1,2$ $\mathrm{mm})$.

Entre os indivíduos simbiontes dos dois substratos foi encontrada diferença significativa de tamanho $(p=0,002)$. Os exemplares associados ao briozoário apresentaram comprimento médio de carapaça de 4,6 $\pm 1,3 \mathrm{~mm}(2,29$ a 8,48 mm) e os indivíduos associados ao poliqueto 4,1 $\pm 1,1 \mathrm{~mm}(1,77$ a $6,41 \mathrm{~mm})$. Em relação ao tamanho entre machos e fêmeas não foi registrada diferença significativa em nenhum dos substratos, portanto não foi observado dimorfismo sexual ( $p>0,05)$. Entre as fêmeas ovígeras e não ovígeras houve diferença significativa em ambos os substratos $(p<0,001)$. As fêmeas ovígeras associadas ao briozoário $(n=72)$ possuem $5,4 \pm 1,2$ $\mathrm{mm}$ de comprimento médio de carapaça, enquanto as não ovígeras ( $\mathrm{n}=47$ ), 3,6 $\pm 0,7$ $\mathrm{mm}$. As fêmeas ovígeras associadas ao poliqueto $(n=63)$ em média medem $4,7 \pm 0,9$ $\mathrm{mm}$ e as não ovígeras $(\mathrm{n}=35) 3,7 \pm 0,9 \mathrm{~mm}$. Para tais análises as fêmeas consideradas recrutas e juvenis foram desconsideradas. 


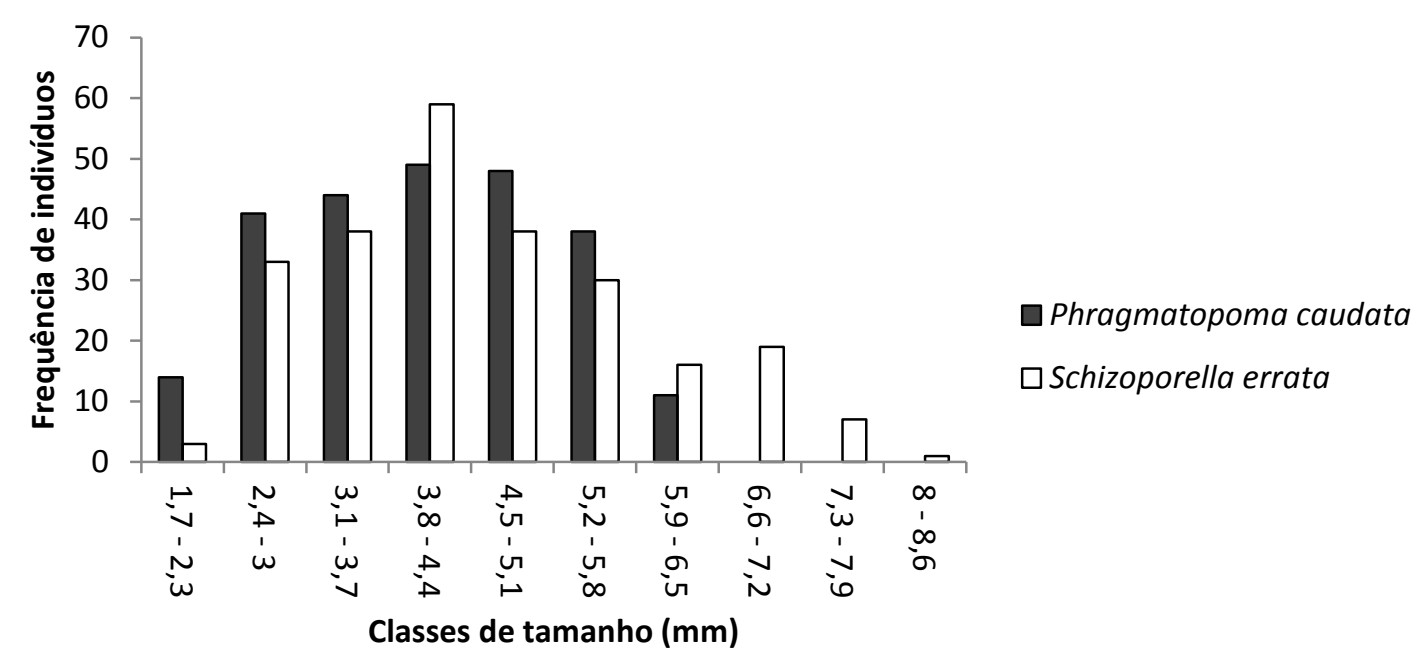

Figura 4: Distribuição de frequência em classes de tamanho dos exemplares de Pachycheles monilifer associados ao briozoário Schizoporella errata e ao poliqueto Phragmatopoma caudata.

No substrato do briozoário, o indivíduos coletados tiveram maior ocorrência na classe de tamanho 3,8 - 4,4 mm com um total de 59 indivíduos, sendo esta também a classe com maior número de machos (31 indivíduos). $\mathrm{Na}$ primeira classe representando os recrutas, foram coletados apenas três indivíduos. A partir da classe, 5,9 - 6,5 mm todas as fêmeas coletadas estavam ovígeras e na última (8,0 - 8,6 mm) não foi coletado nenhum macho, sendo o maior exemplar dos machos medindo 7,88 $\mathrm{mm}$ e a maior ovígera $8,48 \mathrm{~mm}$. A maior ocorrência das fêmeas ovígeras foi na classe 4,5 - 5,1 mm, representada por 15 exemplares (figura 5).

Os indivíduos coletados no substrato do poliqueto tiveram maior ocorrência nas classes de tamanho 3,8 - 4,4 mm e 4,5 - 5,1 mm (48 indivíduos em cada classe), sendo que a maior concentração de machos foi nessa última classe. Diferentemente dos machos associados ao briozoário, os machos simbiontes do poliqueto ocorreram em todas as classes, representando o maior indivíduo coletado nesse substrato com 6,41 $\mathrm{mm}$ de comprimento de carapaça, enquanto que a maior fêmea ovígera media $5,95 \mathrm{~mm}$. Na primeira classe de tamanho, representada pelos recrutas, foram coletados 14 indivíduos. As fêmeas ovígeras tiveram maior ocorrência na classe de tamanho 5,2 - 5,8 mm, representada por 20 exemplares (figura 6). 


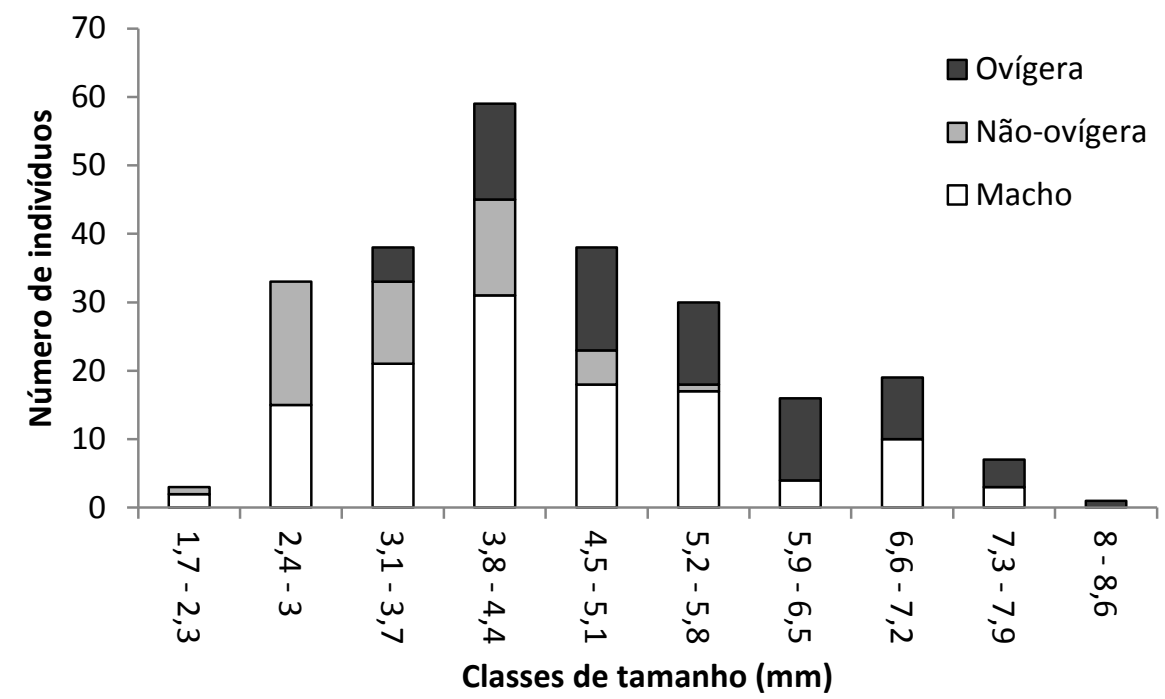

Figura 5: Distribuição de frequência da população de Pachycheles monilifer simbionte do briozoário Schizoporella errata.

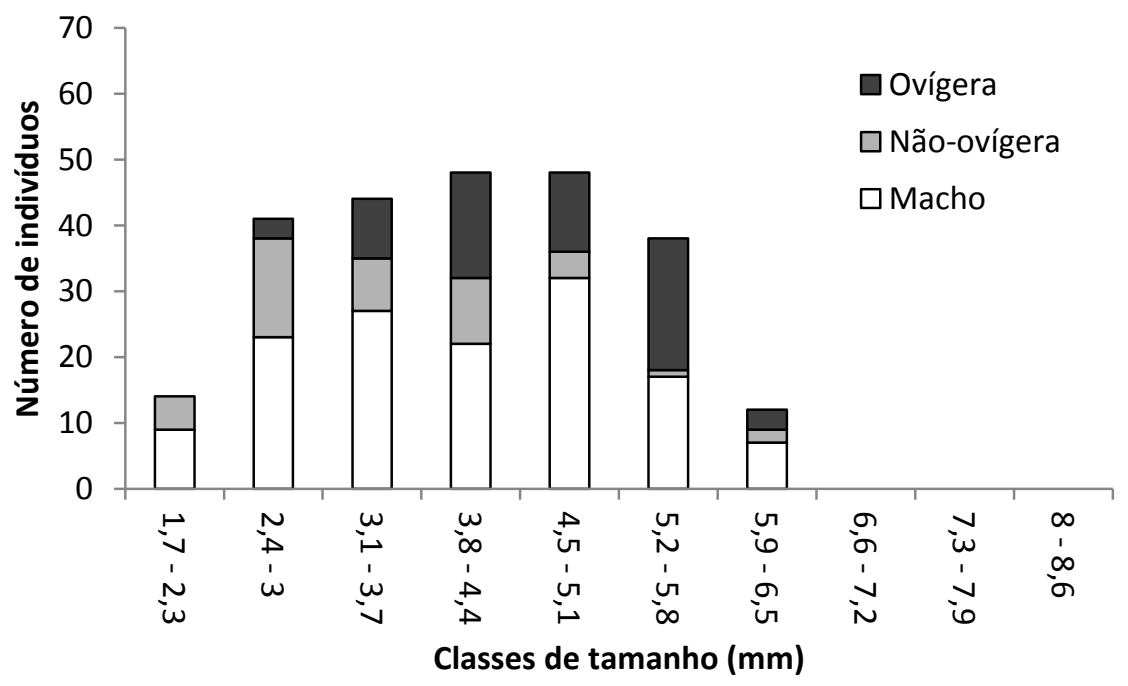

Figura 6: Distribuição de frequência da população de Pachycheles monilifer simbiontes do poliqueto Phragmatopoma caudata. 


\section{Fecundidade}

No total, foram coletadas 72 fêmeas ovígeras associadas ao briozoário e 63 associadas ao poliqueto. Essas se distribuíram por todas as classes de tamanho com exceção das duas primeiras classes no substrato do briozoário $(1,7$ a 3,0 mm) e da primeira classe no substrato do poliqueto $(1,7$ a 2,3 $\mathrm{mm}$ ). As fêmeas ovígeras simbiontes do briozoário possuem uma média de comprimento de carapaça de 5,4 \pm $1,1 \mathrm{~mm}$, sendo que a menor mede $3,31 \mathrm{~mm}$ e a maior $8,48 \mathrm{~mm}$. As ovígeras associadas ao poliqueto possuem uma média de 4,7 $\pm 0,9 \mathrm{~mm}$, variando de 2,62 a $5,95 \mathrm{~mm}$. Foi registrada diferença significativa de tamanho entre as fêmeas ovígeras dos dois substratos $(p<0,001)$, sendo as ovígeras simbiontes do briozoário maiores que as simbiontes do poliqueto.

$\mathrm{Na}$ estação chuvosa os indivíduos associados ao substrato do briozoário apresentaram tamanho médio de 4,6 $\pm 1,3 \mathrm{~mm}$ e na estação seca 4,3 \pm 1,3 $\mathrm{mm}$, não diferindo significativamente entre as estações $(p=0,300)$. As fêmeas ovígeras também não diferiram de tamanho entre as estações $(p=0,880)$, medindo em média $5,4 \pm 1,2 \mathrm{~mm}$ na estação chuvosa e 5,6 $\pm 1,2 \mathrm{~mm}$ na estação seca. Já os indivíduos simbiontes do poliqueto demonstraram diferença significativa entre as estações ( $p<$ 0,001 ), sendo que na chuvosa medem em média $4,8 \pm 0,8 \mathrm{~mm}$ e na estação seca 3,8 $\pm 1,1 \mathrm{~mm}$. As fêmeas ovígeras desse substrato também diferiram significativamente entre as estações $(p<0,001)$, medindo em média 5,0 $\pm 0,7 \mathrm{~mm}$ na estação chuvosa e $4,5 \pm 0,9 \mathrm{~mm}$ na seca.

As fêmeas simbiontes de ambos os substratos portavam embriões nos três estágios de desenvolvimento embrionário, havendo maior frequência no estágio inicial, seguido pelos estágios intermediário e final (tabela 2). Associadas ao briozoário, $66,7 \%$ das fêmeas portavam embriões em estágio inicial de desenvolvimento, $27,8 \%$ em estágio intermediário e 5,5\% em estágio final. No substrato do poliqueto, $60,3 \%$ das fêmeas portavam embriões no início do desenvolvimento, 36,5\% no estágio intermediário e 3,2\% em estágio final. Porém, devido ao baixo n amostral de fêmeas portando embriões em estágio final de desenvolvimento, estas foram computadas junto com as fêmeas de estágio intermediário para as análises de tamanho, volume e perda de embriões. 
Tabela 2: Distribuição de frequência das fêmeas ovígeras de Pachycheles monilifer coletadas associadas ao briozoário Schizoporella errata ao poliqueto Phragmatopoma caudata em relação ao estágio de desenvolvimento embrionário no qual se encontravam os embriões.

\begin{tabular}{ccccc}
\hline \multirow{2}{*}{ Substrato } & \multicolumn{2}{c}{ Estágio de desenvolvimento embrionário } & \multirow{2}{*}{ TOTAL } \\
\cline { 2 - 4 } Schizoporella errata & Inicial & Intermediário & Final & \\
\hline Phragmatopoma caudata & $48(66,7 \%)$ & $20(27,8 \%)$ & $4(5,5 \%)$ & 72 \\
\hline TOTAL & $38(60,3 \%)$ & $23(36,5 \%)$ & $2(3,2 \%)$ & 63 \\
\hline
\end{tabular}

A fecundidade média registrada agrupando-se as fêmeas ovígeras de Pachycheles monilifer de ambos os substratos foi de 123,1 $\pm 185,7$ embriões.

As fêmeas simbiontes do briozoário apresentaram fecundidade média de $174 \pm$ 228 embriões, tendo sido coletado fêmeas com 5 até 860 embriões $(n=48)$. A média de embriões em estágio intermediário/final foi de 242,1 $\pm 247,4(n=24)$, com variação de 5 a 757. Não houve diferença significativa do tamanho das fêmeas que portavam embriões nos diferentes estágios de desenvolvimento $(p=0,078)$.

Já as fêmeas simbiontes do poliqueto portavam uma média de 53,6 \pm 52,8 embriões, com variação de 8 a $233(n=35)$. A média dos embriões de estágio intermediário/final foi 49,3 $\pm 53,7(n=25)$, variando de 5 a 205 embriões. Também não foi encontrada diferença significativa entre o tamanho das fêmeas com embriões nos diferentes estágios de desenvolvimento $(p=0,753)$.

As fêmeas simbiontes do briozoário mostraram ser capazes de produzir em média 3,2 vezes mais embriões que as fêmeas associadas ao poliqueto. Nas duas populações foi observada uma relação significativa entre substrato, comprimento da carapaça e fecundidade $(p=0,01)$. Nas figuras 7 e 8 pode ser observada a relação positiva entre CC e fecundidade nos dois substratos $(r=0,836$; $p<0,05$; figura 7 e $r=$ 0,$560 ; p<0,05$; figura 8). Na tabela 3 estão representados os valores médios, mínimo e máximo do número de embriões nos estágios inicial e intermediário/final em cada classe de tamanho das fêmeas simbiontes do briozoário e do poliqueto, respectivamente. 


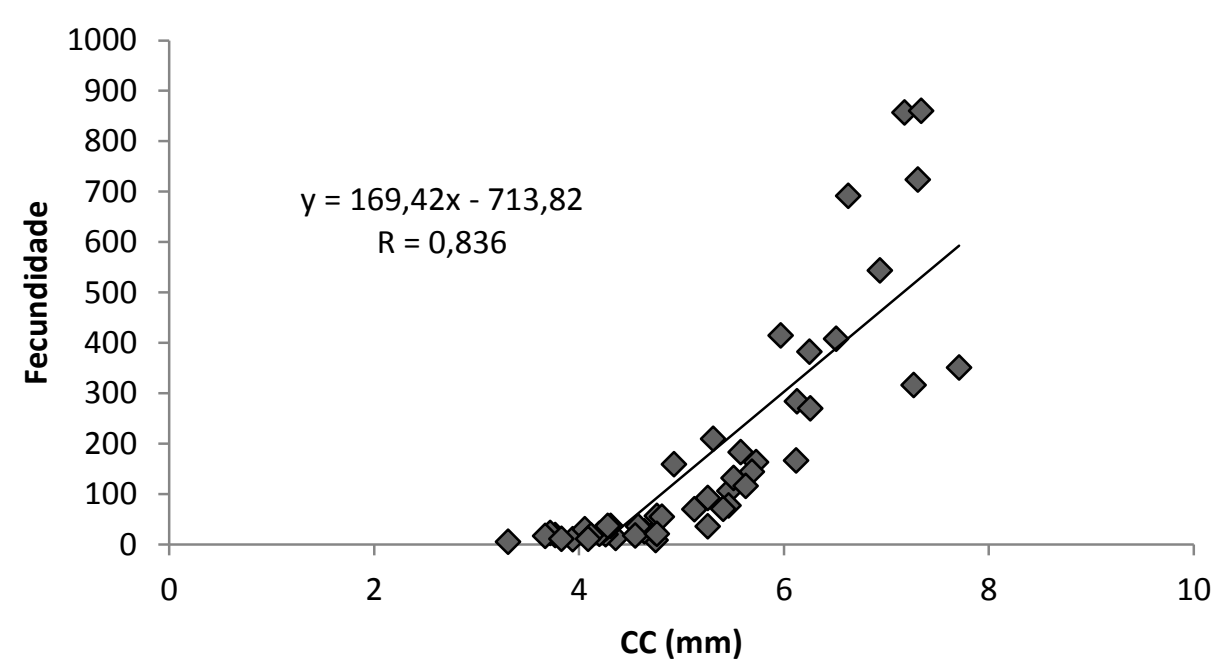

Figura 7: Regressão entre comprimento da carapaça (CC) e fecundidade das fêmeas ovígeras de Pachycheles monilifer simbiontes do briozoário Schizoporella errata.

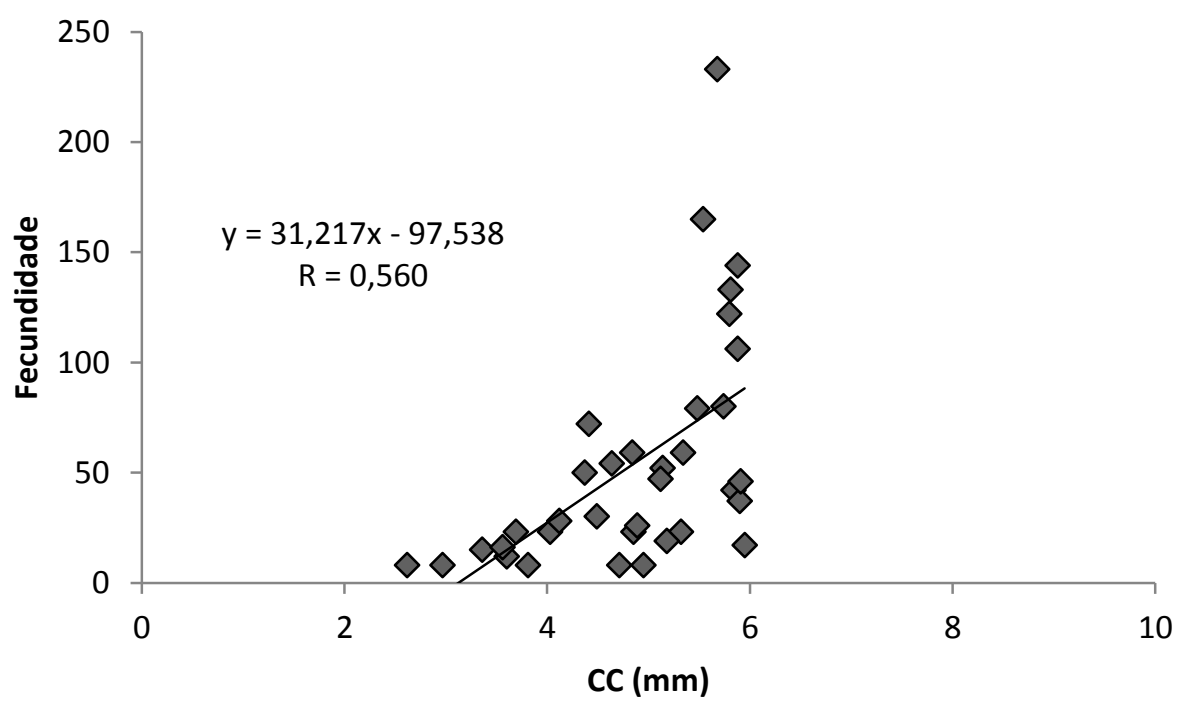

Figura 8: Regressão entre comprimento da carapaça (CC) e fecundidade das fêmeas ovígeras de Pachycheles monilifer simbiontes do poliqueto Phragmatopoma caudata. 
Tabela 3: Variação do número de embriões em estágios inicial e intermediário/final de desenvolvimento das fêmeas de Pachycheles monilifer associadas aos substratos do briozoário Schizoporella errata ao poliqueto Phragmatopoma caudata ( $\mathrm{N}=$ número de fêmeas; Mín./Máx. = número mínimo e máximo de embriões; $x=$ média; $d p=$ desvio padrão).

\begin{tabular}{|c|c|c|c|c|c|c|c|}
\hline \multirow{3}{*}{ 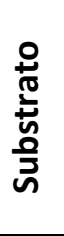 } & \multirow{3}{*}{$\begin{array}{c}\text { Classes de } \\
\text { tamanho }(\mathrm{mm})\end{array}$} & \multicolumn{6}{|c|}{ Estágio } \\
\hline & & \multicolumn{3}{|c|}{ Inicial } & \multicolumn{3}{|c|}{ Intermediário/Final } \\
\hline & & $\mathbf{N}$ & \multicolumn{2}{|c|}{$x \pm d p$} & $\mathbf{N}$ & Mín. & Máx. \\
\hline \multirow{9}{*}{ 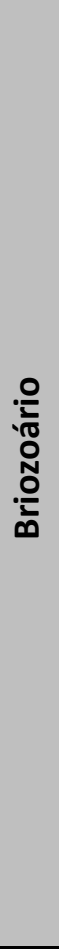 } & $2,4-3,0$ & - & \multicolumn{2}{|c|}{ - } & & \multicolumn{2}{|c|}{ - } \\
\hline & $3,1-3,7$ & 4 & \multicolumn{2}{|c|}{$16 \pm 3$} & 1 & \multicolumn{2}{|c|}{5} \\
\hline & $3,8-4,4$ & 10 & \multicolumn{2}{|c|}{$20,8 \pm 10,4$} & 4 & $18,7 \pm 1,5$ & $5^{21}$ \\
\hline & $4,5-5,1$ & 10 & \multicolumn{2}{|c|}{$47,5 \pm 43,8$} & 5 & \multicolumn{2}{|c|}{$34,8 \pm 13,9$} \\
\hline & $5,2-5,8$ & 11 & \multicolumn{2}{|c|}{$120,9 \pm 51,8$} & 1 & \multicolumn{2}{|c|}{160} \\
\hline & $5,9-6,5$ & 6 & & $\begin{array}{l}415 \\
7\end{array}$ & 6 & & $\begin{array}{l}564 \\
3,7\end{array}$ \\
\hline & $6,6-7,2$ & 4 & $\begin{array}{l}316 \\
602\end{array}$ & $\begin{array}{l}857 \\
9,7\end{array}$ & 5 & $\begin{array}{r}236 \\
46\end{array}$ & $\begin{array}{l}757 \\
, 4\end{array}$ \\
\hline & $7,3-7,9$ & 3 & & $\begin{array}{l}860 \\
5\end{array}$ & 1 & & \\
\hline & $8-8,6$ & - & & & 1 & & \\
\hline & $2,4-3,0$ & 2 & & 8 & 1 & & \\
\hline & $3,1-3,7$ & 4 & & & 2 & 6 & \\
\hline 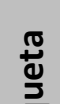 & $3,8-4,4$ & 6 & & & 10 & 5 & \\
\hline 응 & $4,5-5,1$ & 9 & & & 3 & 23 & $\begin{array}{c}48 \\
2,9\end{array}$ \\
\hline & $5,2-5,8$ & 11 & & $\begin{array}{l}233 \\
0,5\end{array}$ & 9 & $\begin{array}{r}45 \\
1\end{array}$ & $\begin{array}{l}205 \\
6,6\end{array}$ \\
\hline & $5,9-6,5$ & 3 & $\begin{array}{r}17 \\
3\end{array}$ & & & & \\
\hline
\end{tabular}


Apesar de ter sido observado um decréscimo no número de embriões do estágio inicial para o intermediário/final em praticamente todas as classes de tamanho em ambos os substratos, não foi observada uma perda significativa ao longo do período de desenvolvimento em nenhuma das populações $(p>0,05)$. As figuras 9 e 10 mostram que há correlação entre o tamanho das fêmeas e o número de embriões nos diferentes estágios de desenvolvimento, não sendo observada tal perda.

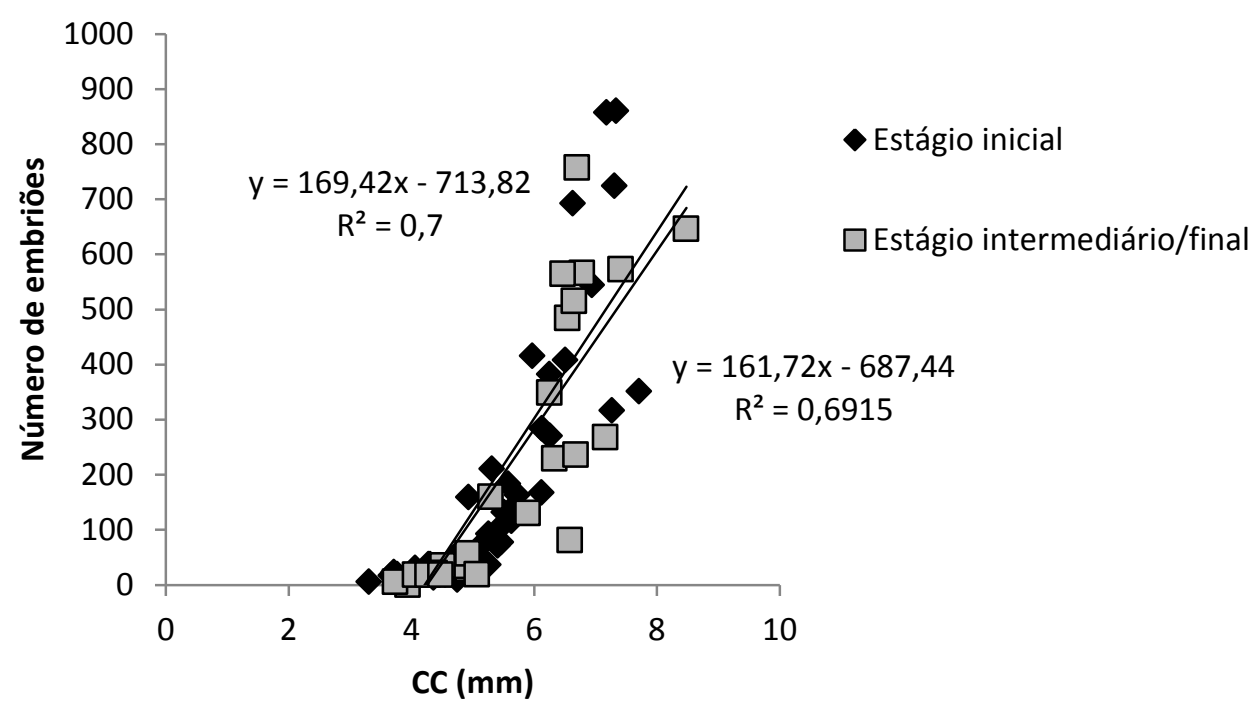

Figura 9: Regressão entre CC $(\mathrm{mm})$ e o número de embriões em estágio inicial e intermediário de desenvolvimento das fêmeas de Pachycheles monilifer simbiontes do briozoário Schizoporella errata.

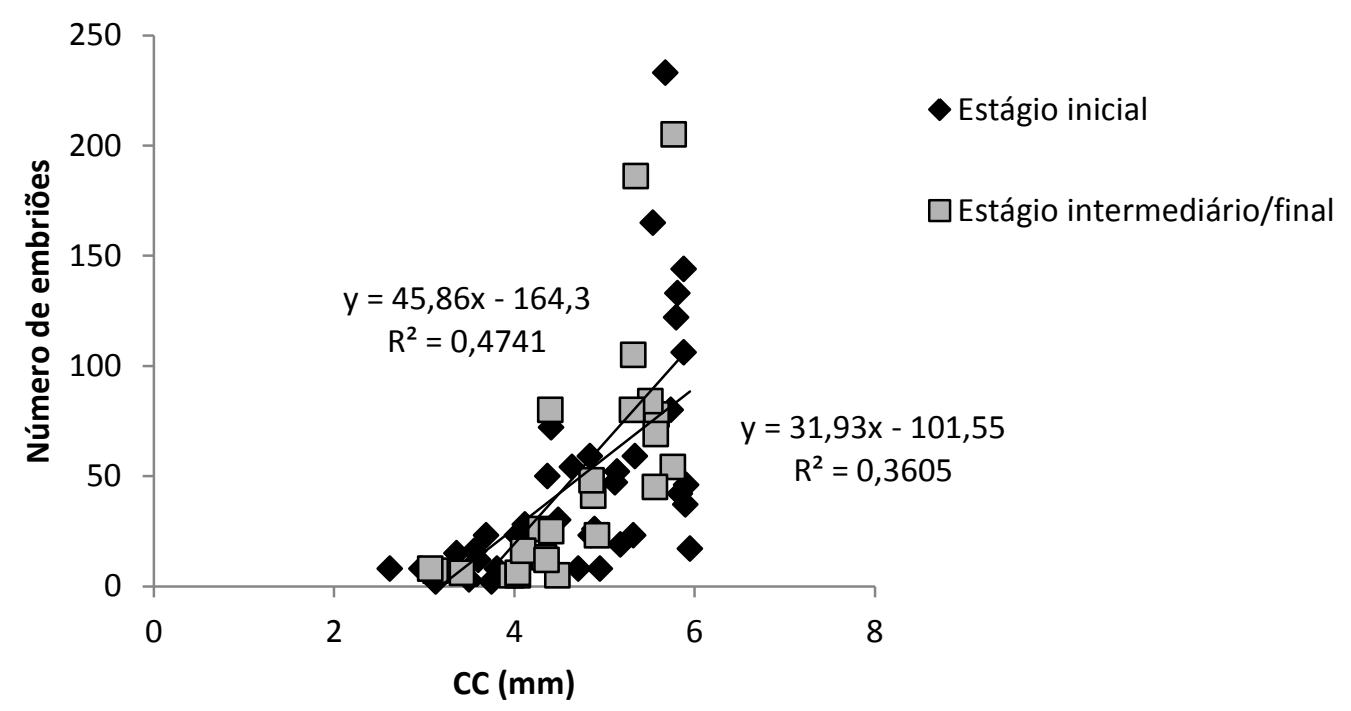

Figura 10: Regressão entre CC ( $\mathrm{mm}$ ) e o número de embriões em estágio inicial e intermediário de desenvolvimento das fêmeas de Pachycheles monilifer simbiontes do poliqueto Phragmatopoma caudata. 
As fêmeas associadas ao briozoário apresentam uma tendência de produzir mais embriões à medida que crescem, porém o mesmo não foi observado nas fêmeas simbiontes do poliqueta. As figuras 11 e 12 mostram a variação da fecundidade das fêmeas simbiontes do briozoário e do poliqueto, respectivamente, em cada classe de tamanho. Apesar das fêmeas associadas ao poliqueto demonstrarem relação positiva entre CC e fecundidade, apresentaram maior fecundidade na classe de tamanho 5,2 $5,8 \mathrm{~mm}$, enquanto as fêmeas da última classe produziram poucos embriões. Nas figuras 11 e 12 pode ser observado a fecundidade média em classes de tamanho de ambos os grupos de fêmeas. Nota-se nitidamente padrões diferentes, com incremento gradativo da fecundidade das fêmeas simbiontes do substrato do briozoário, enquanto que no substrato do poliqueto as maiores fêmeas possuem menor fecundidade, existindo um maior esforço reprodutivo na classe de tamanho 5,2 -5,8mm.

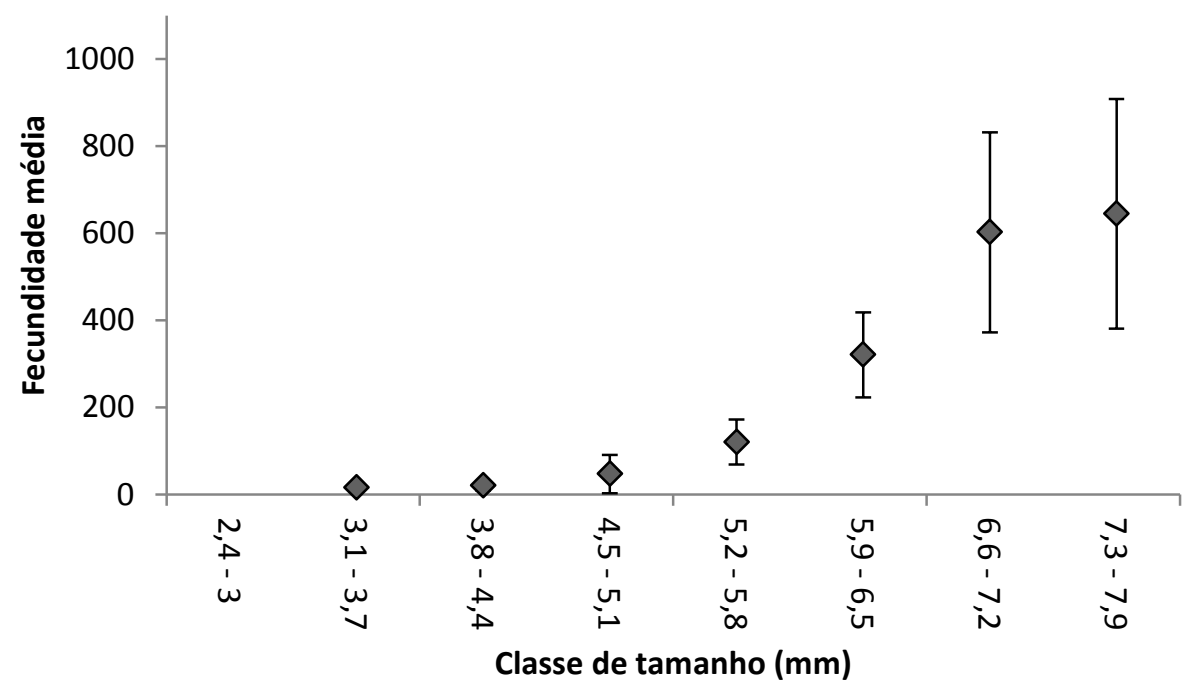

Figura 11: Fecundidade média em classes de tamanho das fêmeas de Pachycheles monilifer simbiontes do briozoário Schizoporella errata. 


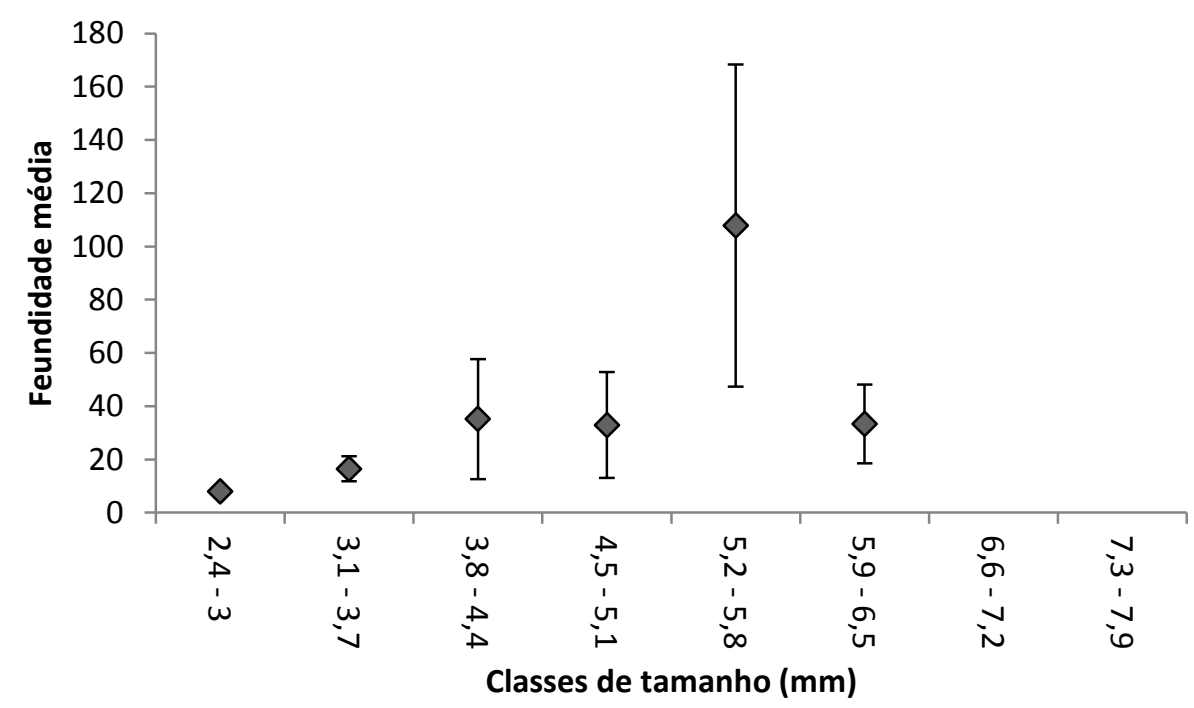

Figura 12: Fecundidade média em classes de tamanho das fêmeas de Pachycheles monilifer simbiontes do poliqueto Phragmatopoma caudata na praia Grande.

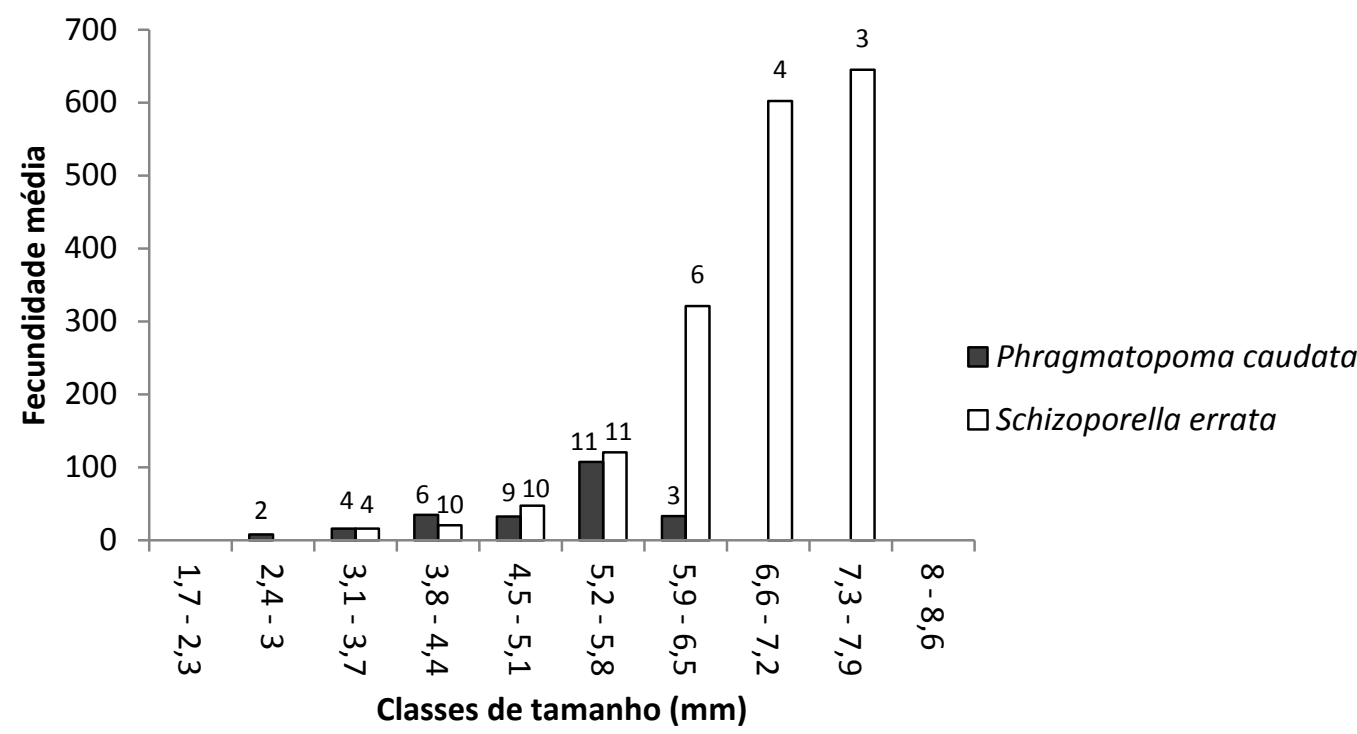

Figura 13: Fecundidade média das fêmeas ovígeras de Pachycheles monilifer associadas ao poliqueto Phragmatopoma caudata e o briozoário Schizoporella errata dentro das classes de tamanho (Números acima das barras representam a frequência absoluta em cada classe de tamanho). 
Em relação às estações do ano, a fecundidade média das fêmeas simbiontes do briozoário na estação seca foi de $178 \pm 142(n=7)$ embriões e na chuvosa 181,7 \pm 244,1 embriões ( $n=39$ ), não sendo encontrada diferença significativa entre as estações ( $p=0,409$, figura 14).

Como as fêmeas simbiontes do poliqueto são maiores na estação chuvosa, também foi encontrada diferença significativa na fecundidade entre as estações ( $p=$ 0,042). Na estação chuvosa as fêmeas apresentaram fecundidade média de 71,8 \pm 62,2 embriões ( $n=13$ ) e na estação seca uma média de 41,1 $\pm 42,8$ embriões ( $n=$ 23). Assim, fica evidente que para reprodução das fêmeas que vivem em simbiose com o poliqueto a estação chuvosa foi mais favorável $(p<0,05$; figura 15).

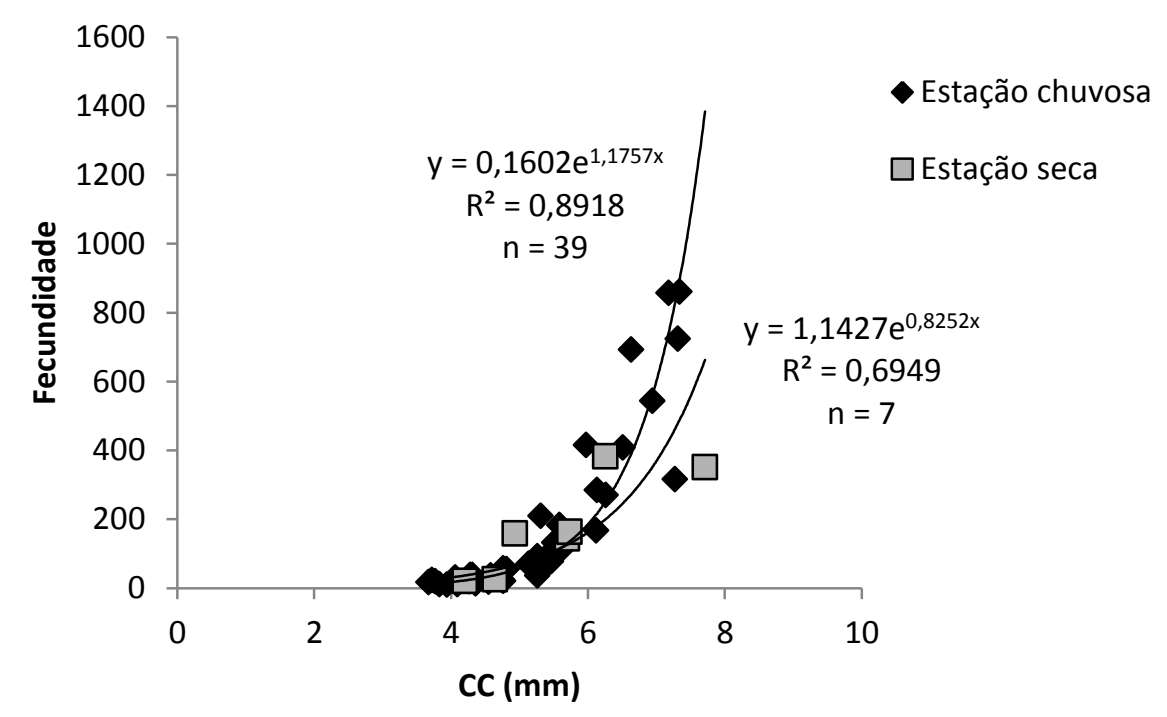

Figura 14: Regressão entre a fecundidade e comprimento da carapaça (CC) nas estações chuvosa e seca das fêmeas de Pachycheles monilifer associadas ao briozoário Schizoporella errata. 


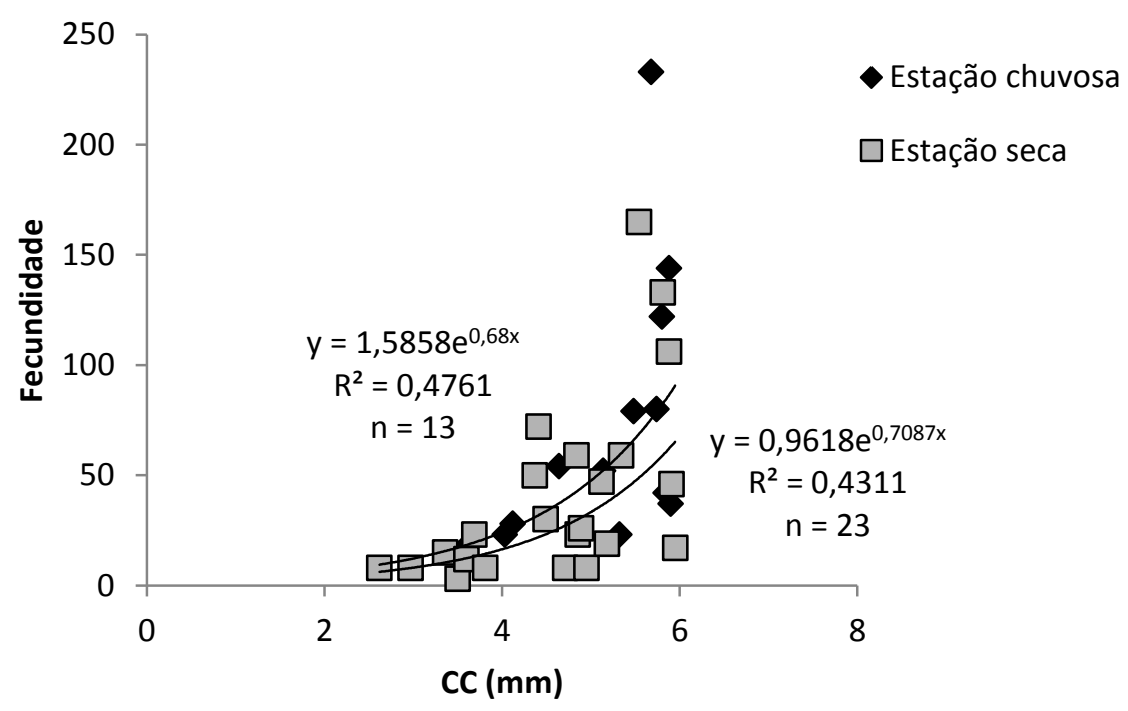

Figura 15: Regressão entre a fecundidade e comprimento da carapaça (CC) nas estações chuvosa e seca das fêmeas de Pachycheles monilifer associadas ao poliqueto Phragmatopoma caudata.

Em relação ao tamanho dos embriões, nas fêmeas simbiontes do briozoário o tamanho médio desses em estágio inicial foi de $0,43 \pm 0,07 \mathrm{~mm}$, resultando num volume médio de $0,04 \pm 0,02 \mathrm{~mm}^{3}$. Para as fêmeas simbiontes do poliqueto o tamanho médio foi de 0,42 $\pm 0,06 \mathrm{~mm}$ e volume médio de 0,04 $\pm 0,01 \mathrm{~mm}^{3}$. Não foi encontrada diferença significativa do tamanho e do volume dos embriões entre os dois grupos de fêmeas $(p>0,05)$. Foi observada uma relação positiva entre o tamanho das fêmeas e o volume dos embriões em estágio inicial em ambos os substratos $(r=0,634 ; p<0,05$; figura 16 e $r=0,608 ; p<0,05$; figura 17). 


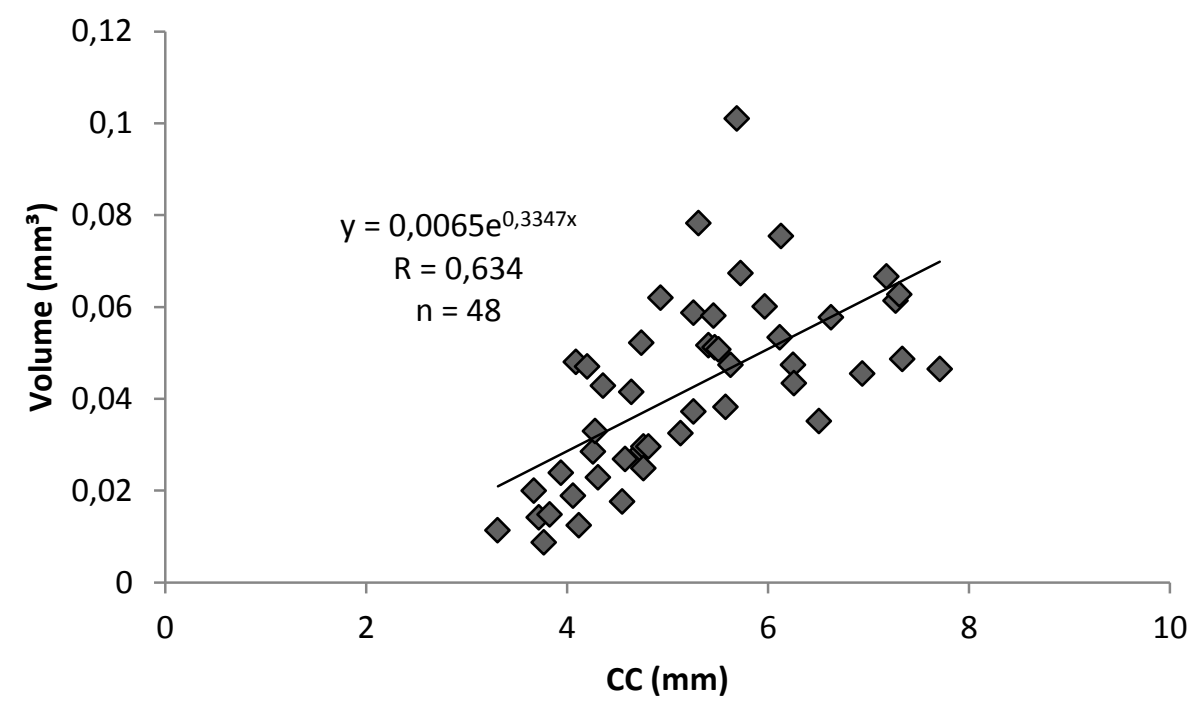

Figura 16: Regressão entre o comprimento da carapaça (CC) e volume dos embriões em estágio inicial de desenvolvimento das fêmeas de Pachycheles monilifer associadas ao briozoário Schizoporella errata.

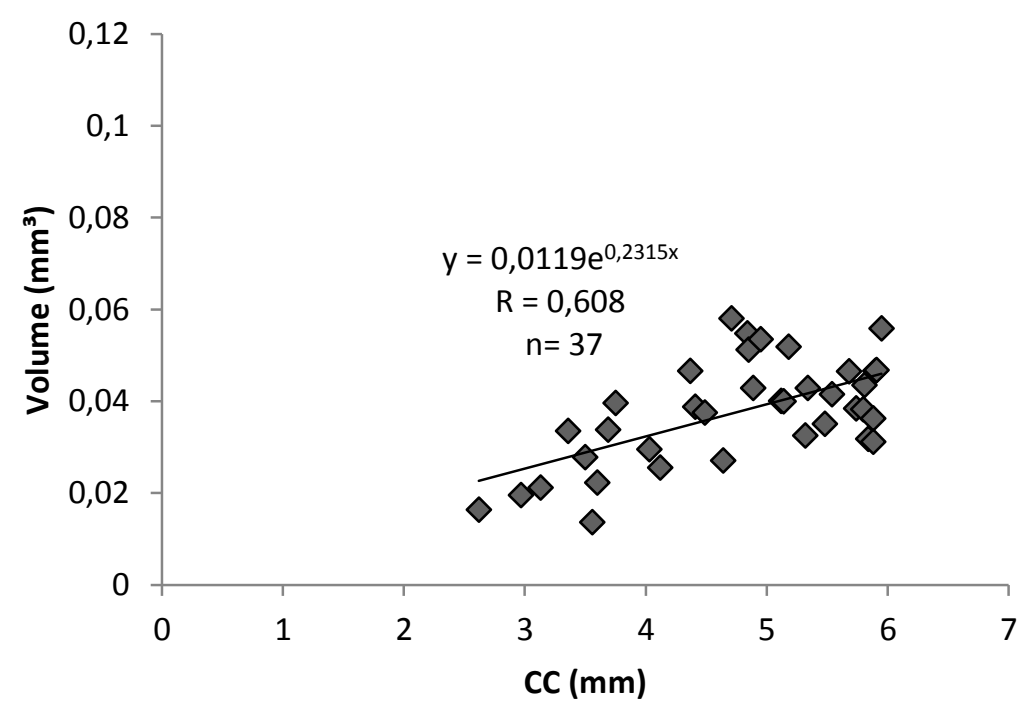

Figura 17: Regressão entre o comprimento da carapaça (CC) e volume dos embriões em estágio inicial de desenvolvimento das fêmeas de Pachycheles monilifer associadas ao poliqueto Phragmatopoma caudata. 
Foi observado um aumento significativo do tamanho e do volume ao longo do período de incubação dos embriões nos dois grupos de fêmeas $(p<0,001)$. Nas fêmeas associadas ao briozoário o aumento do tamanho dos embriões foi de 0,43 \pm $0,07 \mathrm{~mm}$ para $0,58 \pm 0,1 \mathrm{~mm}$, resultando no aumento de volume de 0,04 $\pm 0,02 \mathrm{~mm}^{3}$ para 0,1 $\pm 0,04 \mathrm{~mm}^{3}$. Os embriões das fêmeas simbiontes do poliqueto tiveram um aumento de 0,42 $\pm 0,06 \mathrm{~mm}$ para 0,55 $\pm 0,11 \mathrm{~mm}$, sendo que o volume aumentou de $0,04 \pm 0,01 \mathrm{~mm}^{3}$ para $0,1 \pm 0,04 \mathrm{~mm}^{3}$. Em ambos os substratos os embriões tiveram um aumento de $150 \%$ do volume do estágio inicial para o intermediário/final. Nas figuras 18 e 19 pode ser observado esse aumento do volume.

Em relação às estações seca e chuvosa, não foi encontrada diferença significativa entre o volume dos embriões em nenhum dos grupos de fêmeas ( $p>$ 0,05). Os embriões em estágio inicial das simbiontes do briozoário apresentaram uma média de volume na estação chuvosa de $0,04 \pm 0,02 \mathrm{~mm}^{3}$ e na seca 0,05 $\pm 0,01 \mathrm{~mm}^{3}$. Nas fêmeas simbiontes do poliqueto a média na estação chuvosa foi $0,03 \pm 0,09 \mathrm{~mm}^{3}$ e na seca $0,04 \pm 0,01 \mathrm{~mm}^{3}$.

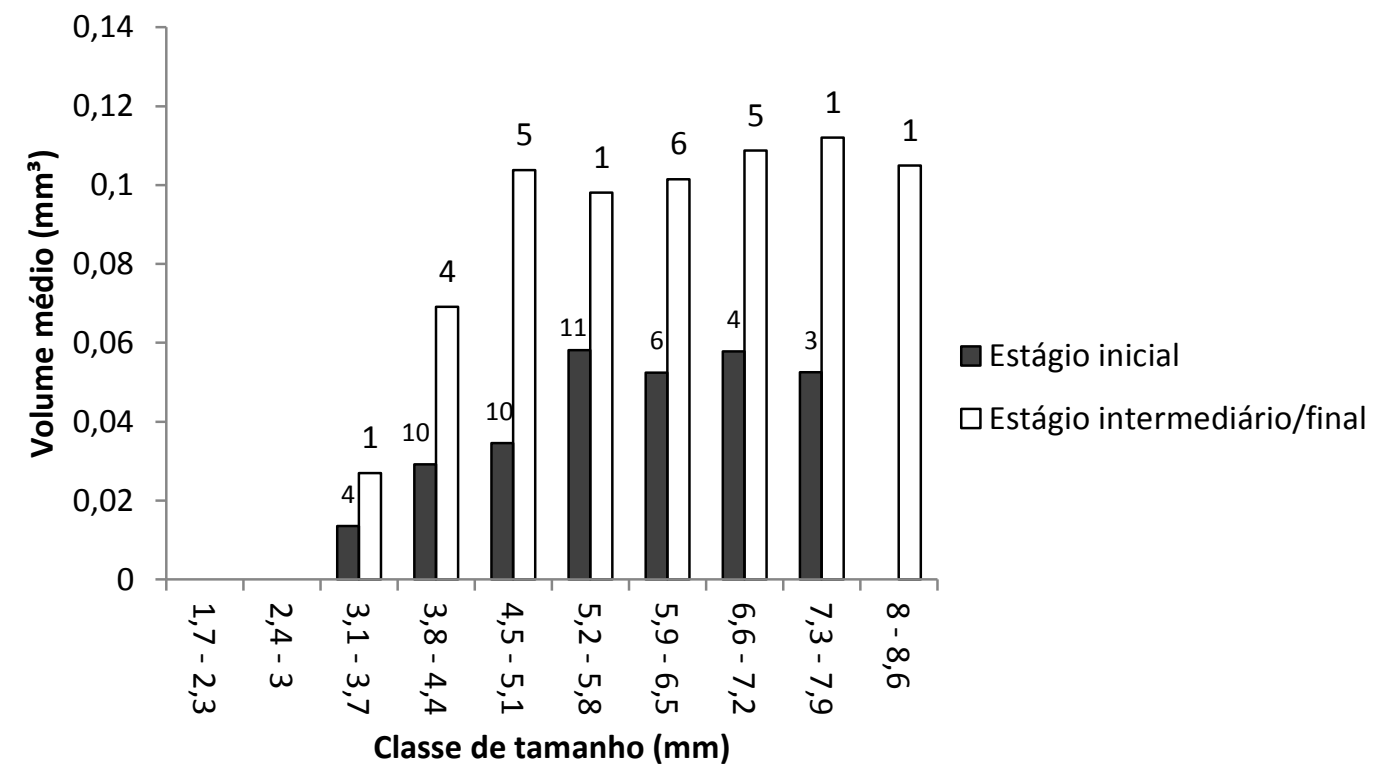

Figura 18: Distribuição das médias de volume dos embriões em estágios inicial e intermediário/final de desenvolvimento das fêmeas de Pachycheles monilifer associadas ao briozoário Schizoporella errata (números acima das barras corresponde ao número de fêmeas ovígeras). 


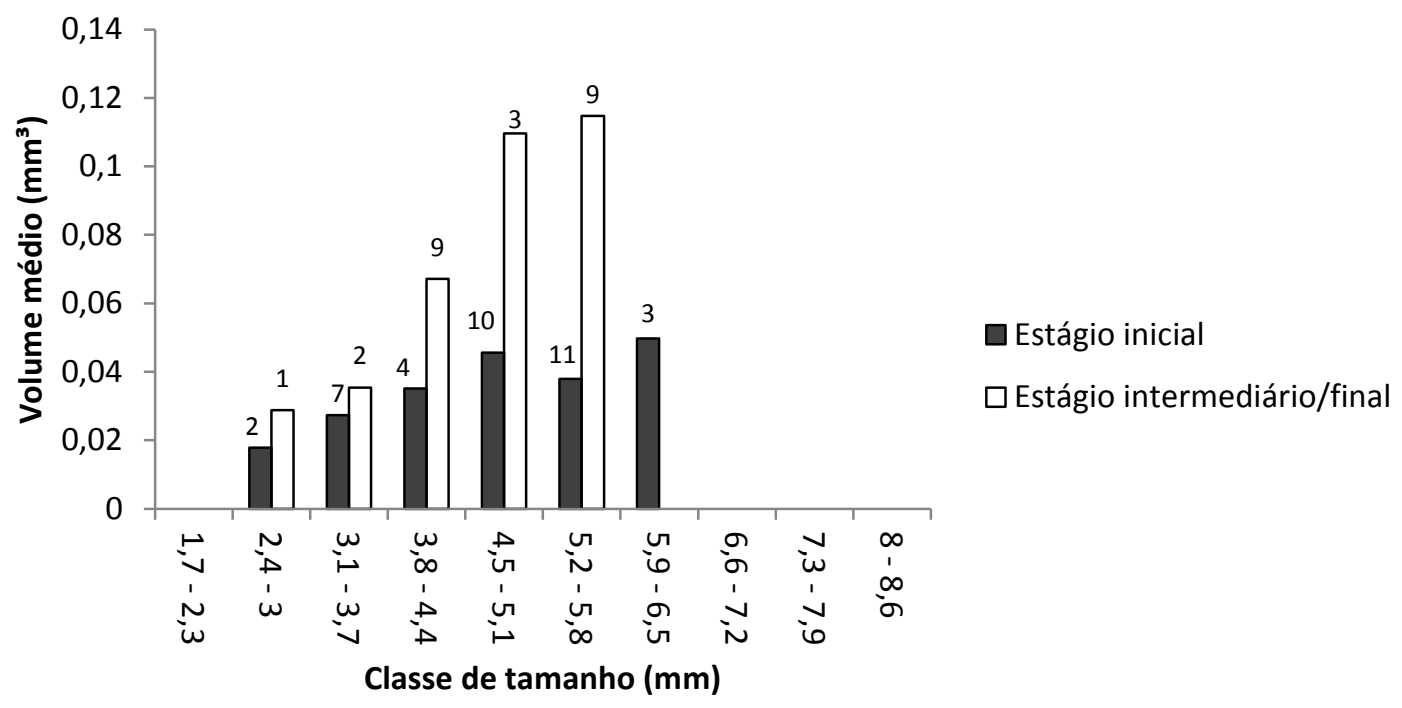

Figura 19: Distribuição das médias de volume dos embriões em estágios inicial e intermediário/final de desenvolvimento das fêmeas de Pachycheles monilifer associadas ao poliqueto Phragmatopoma caudata (números acima das barras corresponde ao número de fêmeas ovígeras).

\section{Investimento reprodutivo (RO)}

O investimento reprodutivo das fêmeas da espécie $P$. monilifer associadas a ambos os substratos foi de $2,0 \pm 2,4 \%(n=76)$ em relação ao seu peso seco. Porém, foi encontrada uma grande variação de energia destinada à reprodução, sendo que o mínimo investido foi $0,13 \%$ e o máximo $14,5 \%$ do peso seco da fêmea. Esse investimento quando calculado a partir do peso úmido das fêmeas e da massa de embriões, resultou numa média de $3,7 \%(n=83)$ do peso da fêmea, com variação de $0,12 \%$ a $20,4 \%$. A diferença de resultados obtidos entre as duas metodologias foi significativa ( $p=0,001$ ), sendo o RO calculado a partir do peso úmido maior que o calculado pelo peso seco $(p<0,05$; figura 20$)$.

Mais especificamente, as fêmeas simbiontes do briozoário investiram em média $2,7 \pm 2,8 \%(n=45)$ do seu peso seco na produção de embriões, apresentando uma variação de $0,2 \%$ a $14,5 \%$. Seguindo o mesmo padrão da fecundidade, essas fêmeas apresentaram uma tendência em investir mais energia na reprodução à medida que crescem ( $r=0,715 ; p<0,05$; figura 21), porém a fêmea com maior RO não corresponde à maior fêmea coletada. A maior fêmea $(7,71 \mathrm{~mm})$ apresentou um investimento de apenas 2,5\% com 351 embriões, enquanto a fêmea que destinou mais energia na reprodução (14,5\% e 7,31 mm de CC) produziu 724 embriões. Entretanto, 
nota-se que há uma relação positiva entre fecundidade e $R O(r=0,861 ; p<0,05$, figura 22), apesar de algumas fêmeas apresentarem alta fecundidade e baixo investimento reprodutivo.

Já as fêmeas simbiontes do poliqueto apresentaram um investimento reprodutivo que variou de 0,1 a $4,9 \%$ do peso seco da fêmea, investindo em média 1,1 $\pm 1,0 \%(n=31)$, de energia na reprodução. A maior fêmea $(5,95 \mathrm{~mm})$ foi a que menos investiu na reprodução, com apenas 17 embriões, representando $0,13 \%$ do seu peso. Entre essas fêmeas não foi registrada relação significativa entre RO e CC $(r=0,244$; $p$ $<0,05$; figura 23), somente entre $R O$ e fecundidade $(r=0,721 ; p<0,05$; figura 24). A fêmea que mais destinou energia à produção dos embriões (4,9\%) também é a fêmea com maior fecundidade (233 embriões, $5,68 \mathrm{~mm}$ ).

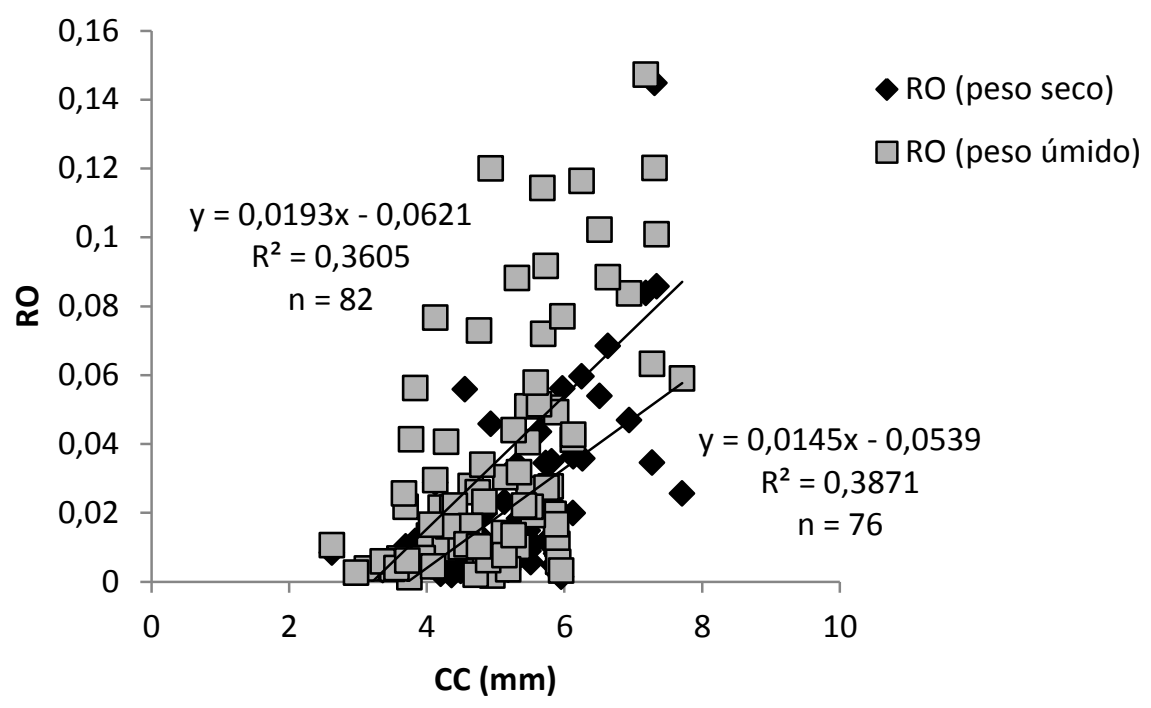

Figura 20: Regressão entre comprimento da carapaça (CC) e o investimento reprodutivo $(\mathrm{RO})$ calculado a partir dos pesos seco e úmido das fêmeas ovígeras de Pachycheles monilifer coletadas nos substratos do briozoário e do poliqueto nas praias de Ubatuba. 


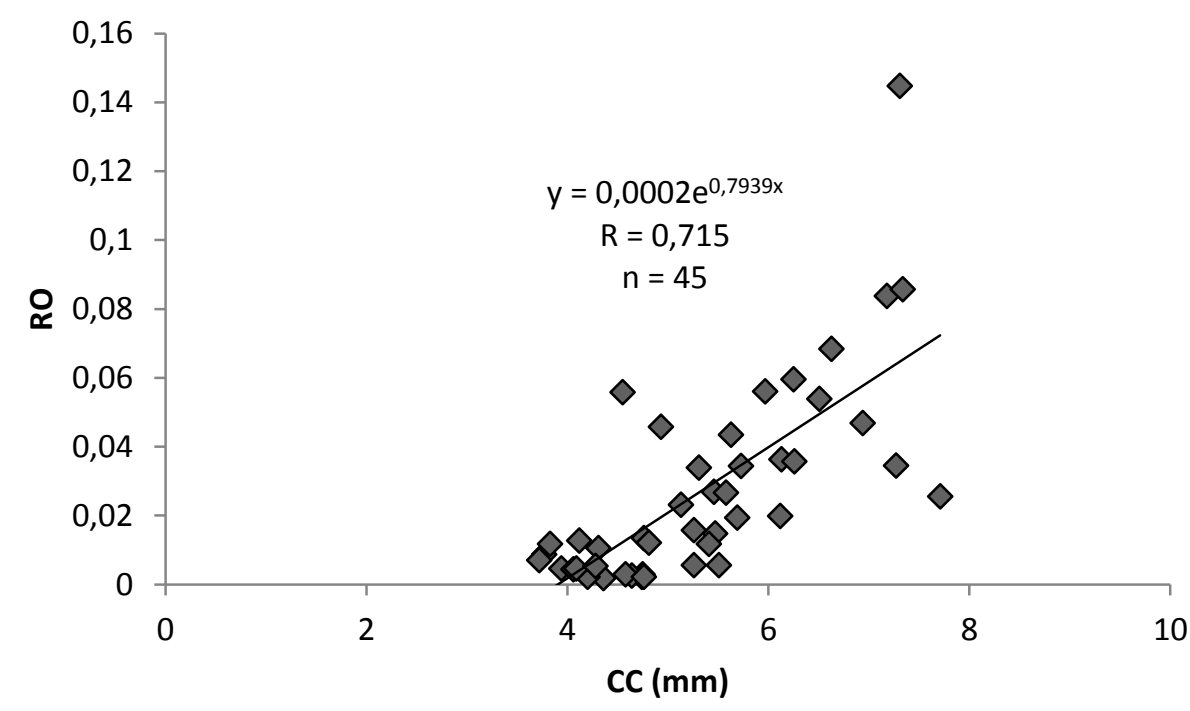

Figura 21: Regressão entre o tamanho (CC) e o investimento reprodutivo (RO) das fêmeas ovígeras de Pachycheles monilifer simbiontes do briozoário Schizoporella errata.

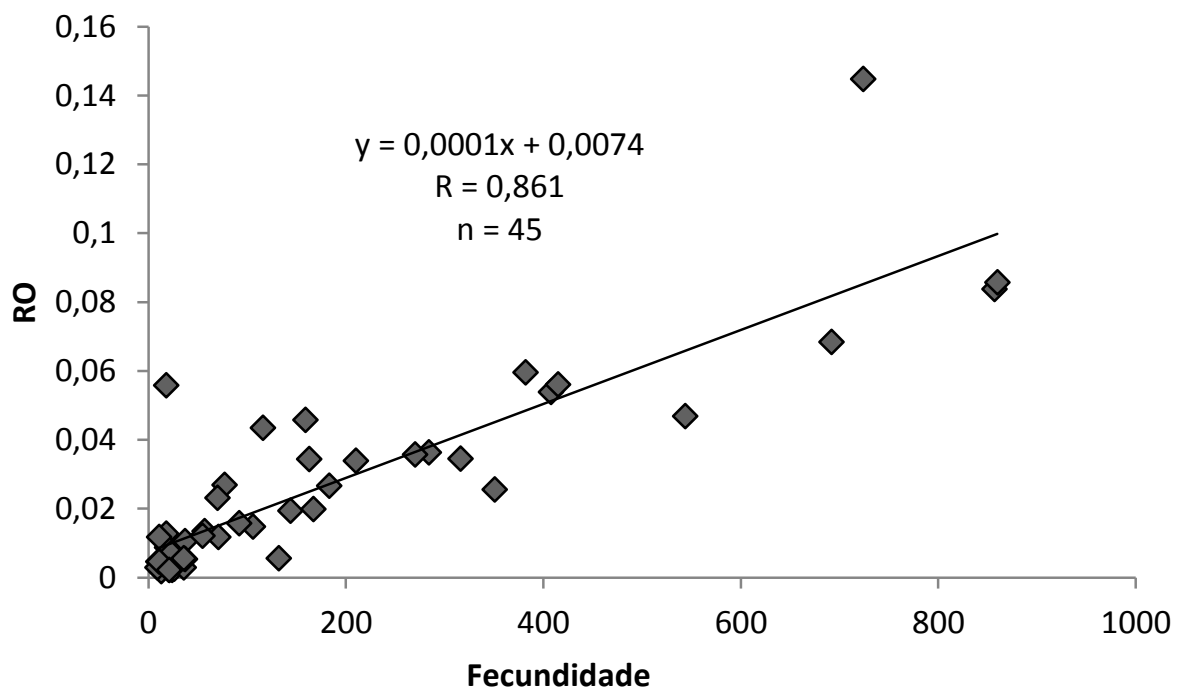

Figura 22: Regressão entre a fecundidade e o investimento reprodutivo (RO) das fêmeas ovígeras de Pachycheles monilifer simbiontes do briozoário Schizoporella errata. 


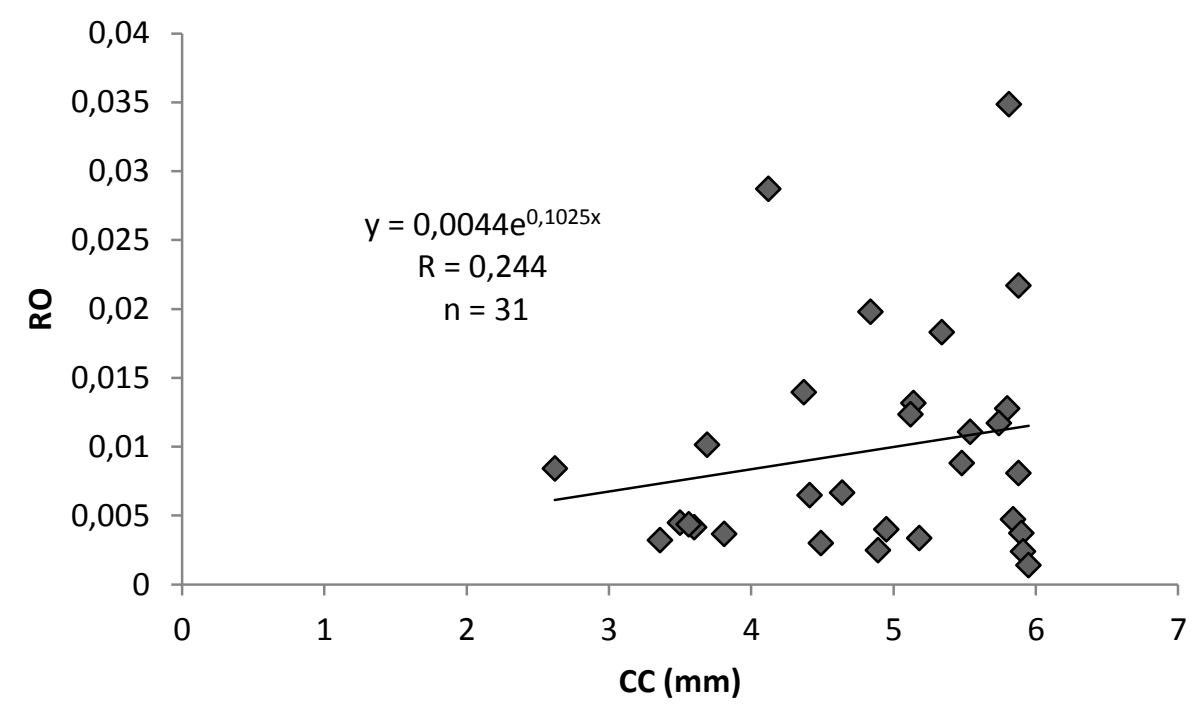

Figura 23: Regressão entre o tamanho (CC) e o investimento reprodutivo $(\mathrm{RO})$ das fêmeas ovígeras de Pachycheles monilifer simbiontes do poliqueto Phragmatopoma caudata.

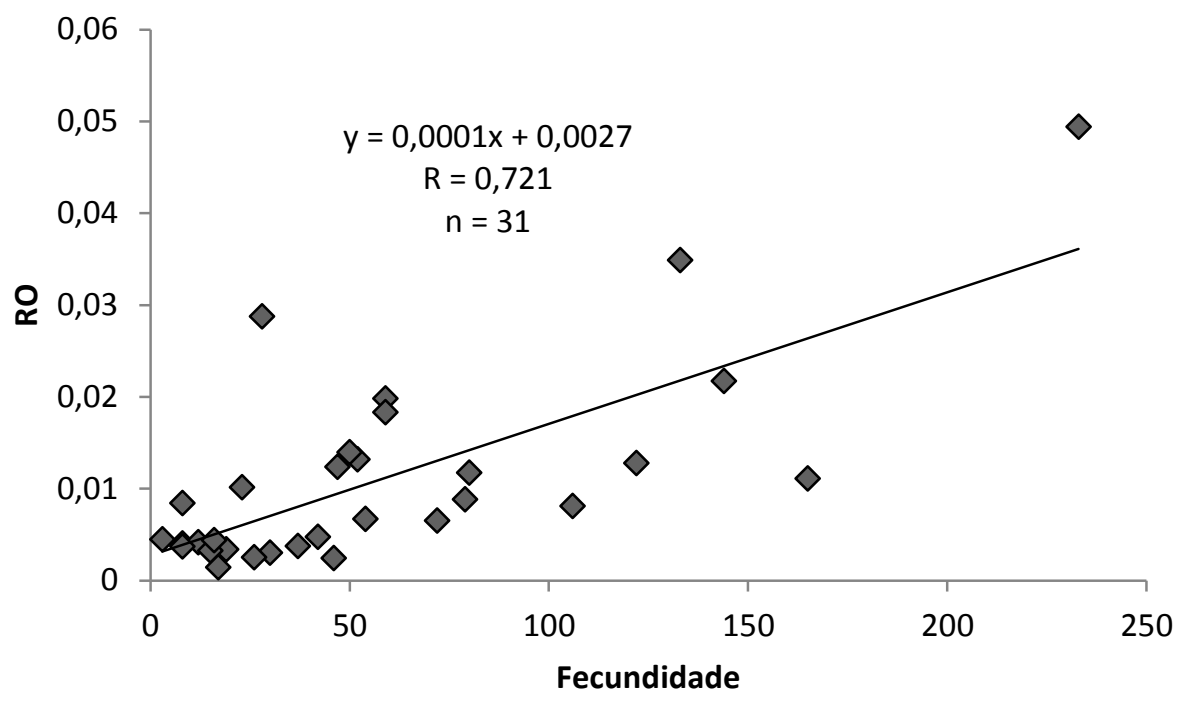

Figura 24: Regressão entre a fecundidade e o investimento reprodutivo (RO) das fêmeas ovígeras de Pachycheles monilifer simbiontes do poliqueto Phragmatopoma caudata. 
As fêmeas ovígeras simbiontes de ambos os substratos apresentaram uma relação significativa $(p=0,03)$ entre o tipo de substrato ocupado, comprimento de carapaça e investimento reprodutivo, onde o RO é resultado da interação entre as outras duas variáveis. Assim como na fecundidade, fêmeas simbiontes do briozoário demonstram investir cerca de duas vezes e meia mais energia na produção de embriões do que as fêmeas associadas ao poliqueto.

Foi observado que o RO das fêmeas associadas ao briozoário aumenta gradativamente ao longo das classes de tamanho, entretanto nas fêmeas simbiontes do poliqueto essa tendência não foi observada (figuras 25 e 26 , respectivamente). Nas fêmeas associadas ao poliqueto foi encontrada uma grande variação de $R O$. A classe de tamanho que mais investiu na reprodução foi a 5,2 - 5,8 $\mathrm{mm}$ e última classe de tamanho $(5,9-6,5 \mathrm{~mm})$ foi a que apresentou o menor $\mathrm{RO}$, podendo ser devido ao baixo $n$ amostral $(n=3)$. Na tabela 4 pode ser observada a variação do investimento reprodutivo das fêmeas simbiontes do substrato do briozoário e do poliqueto.

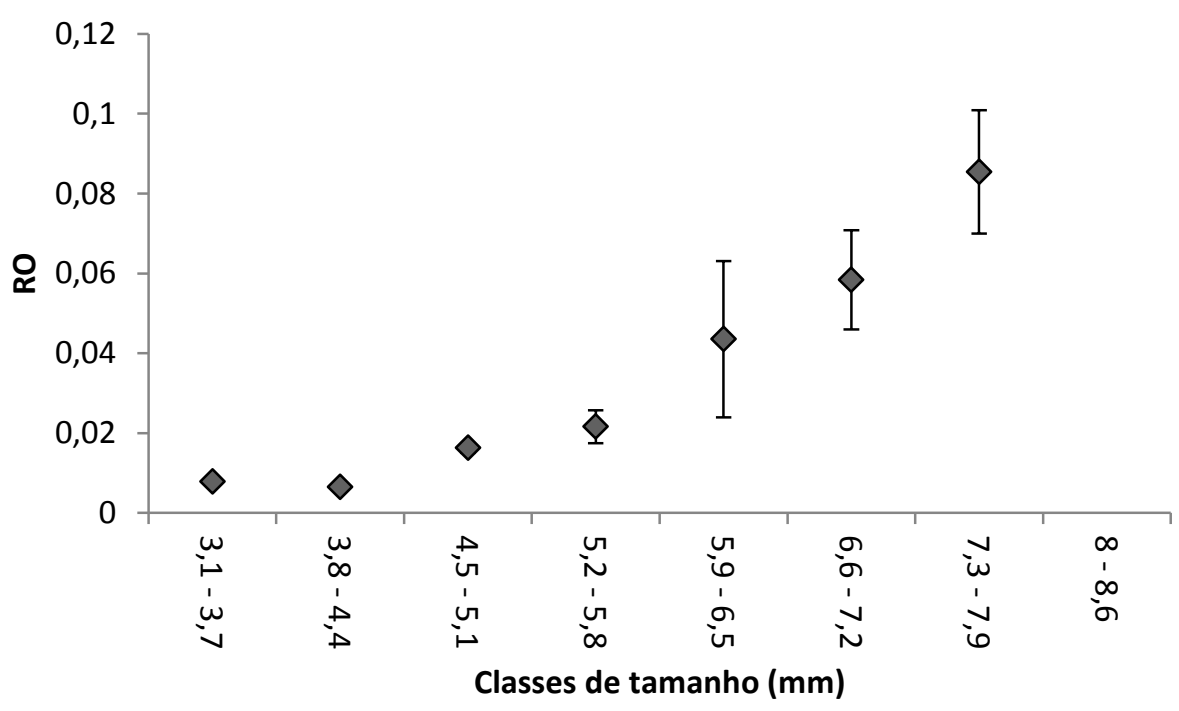

Figura 25: Investimento reprodutivo (RO) médio nas classes de tamanho das fêmeas ovígeras de Pachycheles monilifer simbiontes do briozoário Schizoporella errata. 


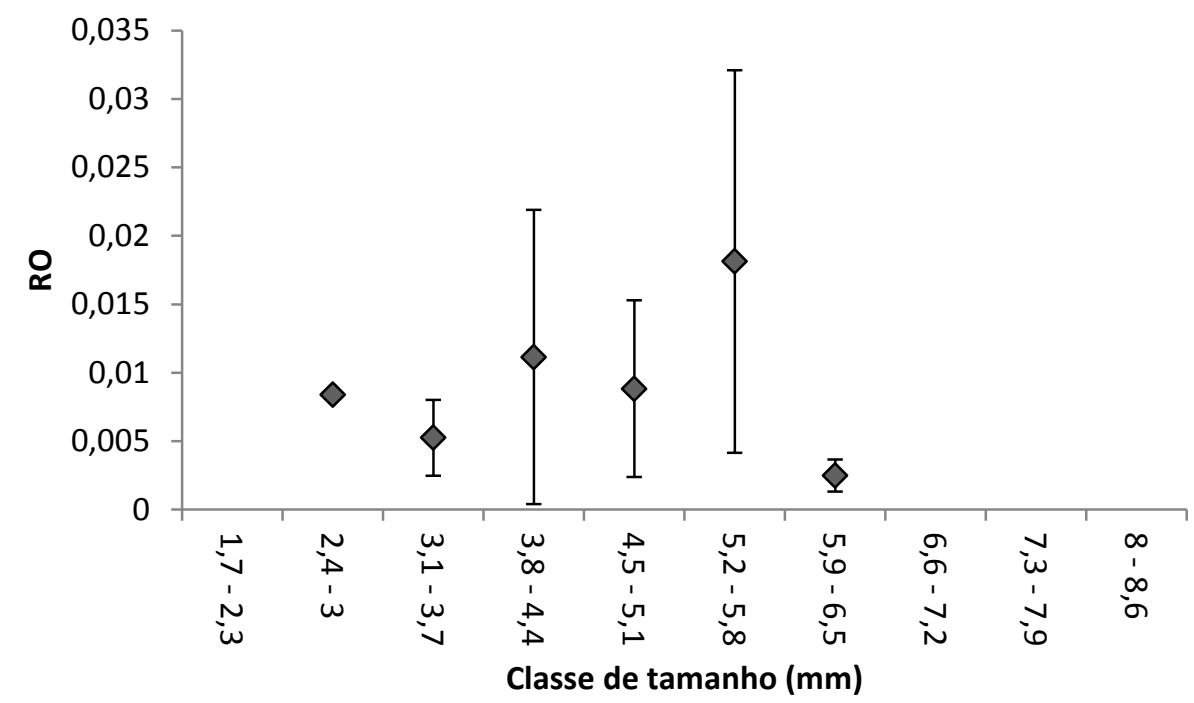

Figura 26: Investimento reprodutivo $(\mathrm{RO})$ médio nas classes de tamanho das fêmeas ovígeras de Pachycheles monilifer simbiontes do poliqueto Phragmatopoma caudata.

Tabela 4: Variação do investimento reprodutivo (RO) nas classes de tamanho das fêmeas ovígeras de Pachycheles monilifer associadas ao briozoário Schizoporella errata ao poliqueto Phragmatopoma caudata $(\mathrm{N}=$ número de fêmeas; $\mathrm{x}=$ média; $\mathrm{dp}=$ desvio padrão).

\begin{tabular}{|c|c|c|c|c|}
\hline \multirow{3}{*}{$\begin{array}{c}\text { Classes de } \\
\text { tamanho }(\mathrm{mm})\end{array}$} & \multicolumn{4}{|c|}{ RO } \\
\hline & \multicolumn{2}{|c|}{ Substrato do Briozoário } & \multicolumn{2}{|c|}{ Substrato do Poliqueto } \\
\hline & $\mathbf{N}$ & $X(\%) \pm d p$ & $\mathbf{N}$ & $X(\%) \pm d p$ \\
\hline $2,4-3$ & & - & 1 & 0,8 \\
\hline $3,1-3,7$ & 2 & $0,8 \pm 0,1$ & 5 & $0,5 \pm 0,2$ \\
\hline $3,8-4,4$ & 9 & $0,6 \pm 0,4$ & 5 & $1,1 \pm 1,0$ \\
\hline $4,5-5,1$ & 10 & $1,6 \pm 1,9$ & 7 & $0,9 \pm 0,6$ \\
\hline $5,2-5,8$ & 11 & $2,2 \pm 1,2$ & 10 & $1,8 \pm 1,3$ \\
\hline $5,9-6,5$ & 6 & $4,4 \pm 1,5$ & 3 & $0,3 \pm 0,1$ \\
\hline $6,6-7,2$ & 4 & $5,8 \pm 2,2$ & & - \\
\hline $7,3-7,9$ & 3 & $8,5 \pm 5,9$ & & - \\
\hline
\end{tabular}


Assim como a fecundidade, o investimento reprodutivo das fêmeas associadas ao briozoário não diferiu significativamente entre as estações seca e chuvosa ( $p=$ 0,409; figura 27), sendo que em ambas as estações foi registrada média de 2,7 \pm $0,3 \%$. As fêmeas simbiontes do poliqueto na estação seca apresentaram uma média $0,9 \pm 0,8 \%$ e na chuvosa $1,5 \pm 1,3 \%$, porém não são significativamente diferentes ( $p=$ 0,063; figura 28).

Em relação ao investimento reprodutivo calculado a partir do peso úmido, as fêmeas simbiontes do briozoário apresentaram um investimento energético de 5,2 \pm $4,3 \%$ ( $n=46)$, variando de 0,4 a $20,4 \%$. O valor médio de $\mathrm{RO}$ obtido a partir do peso úmido é o dobro do RO calculado utilizando o peso seco, diferindo significativamente $(p<0,001)$. Já para as fêmeas associadas ao poliqueto foi obtido um investimento energético médio de 1,8 $\pm 2,1 \%(n=37)$ a partir do peso úmido, variando de 0,1 a $11,4 \%$. Nessas fêmeas o RO calculado a partir do peso seco e úmido são semelhantes e não demonstraram diferença significativa $(p=0,125)$. Na figura 29 é perceptível a diferença de metodologias entre o uso do peso seco e do peso úmido, entretanto o mesmo não pode ser observado na figura 30. 


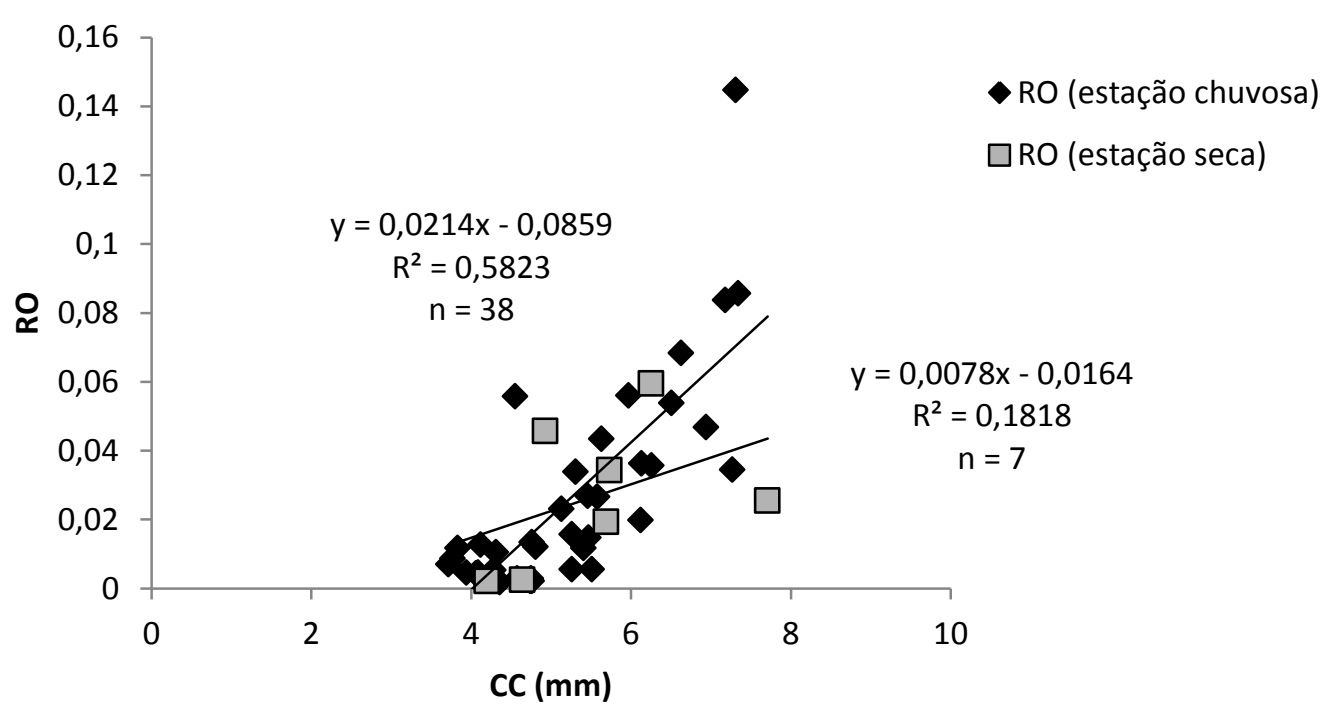

Figura 27: Regressão entre investimento reprodutivo (RO) e comprimento da carapaça (CC) nas estações chuvosa e seca das fêmeas de Pachycheles monilifer associadas ao briozoário Schizoporella errata.

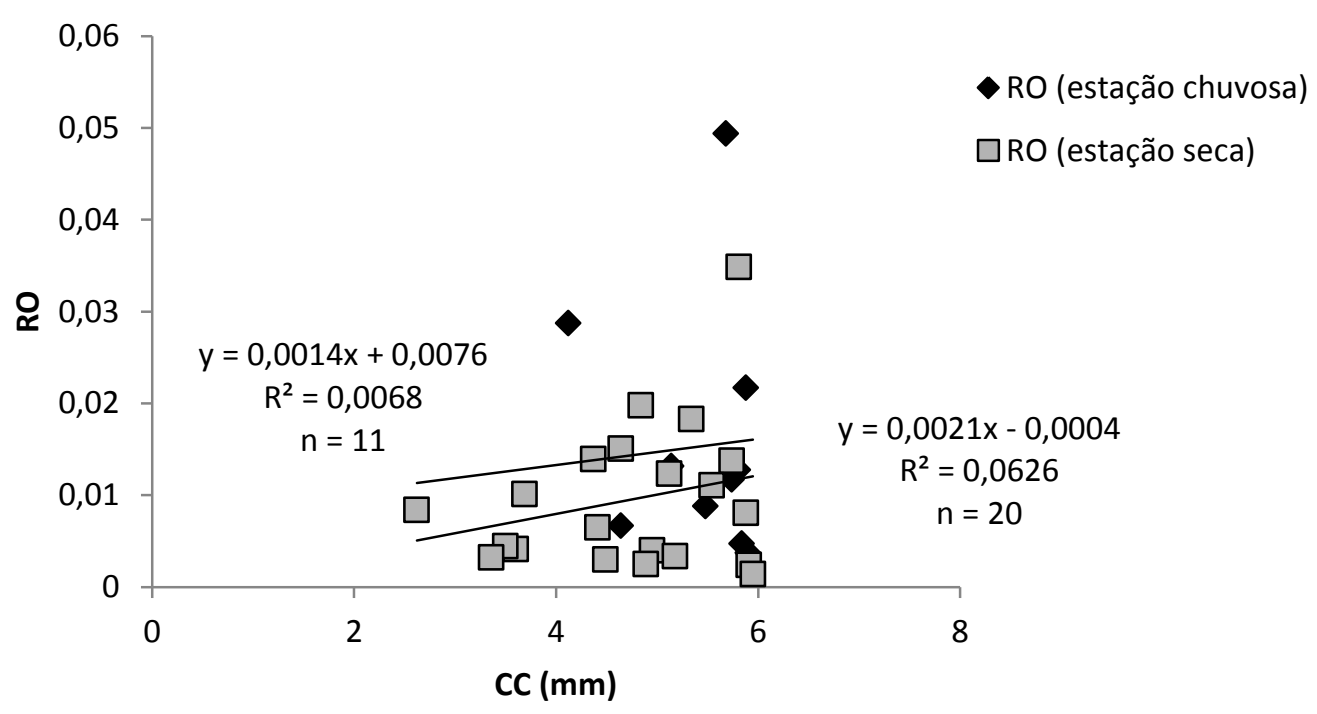

Figura 28: Regressão entre o investimento reprodutivo (RO) e comprimento da carapaça (CC) nas estações chuvosa e seca das fêmeas de Pachycheles monilifer associadas ao poliqueto Phragmatopoma caudata. 


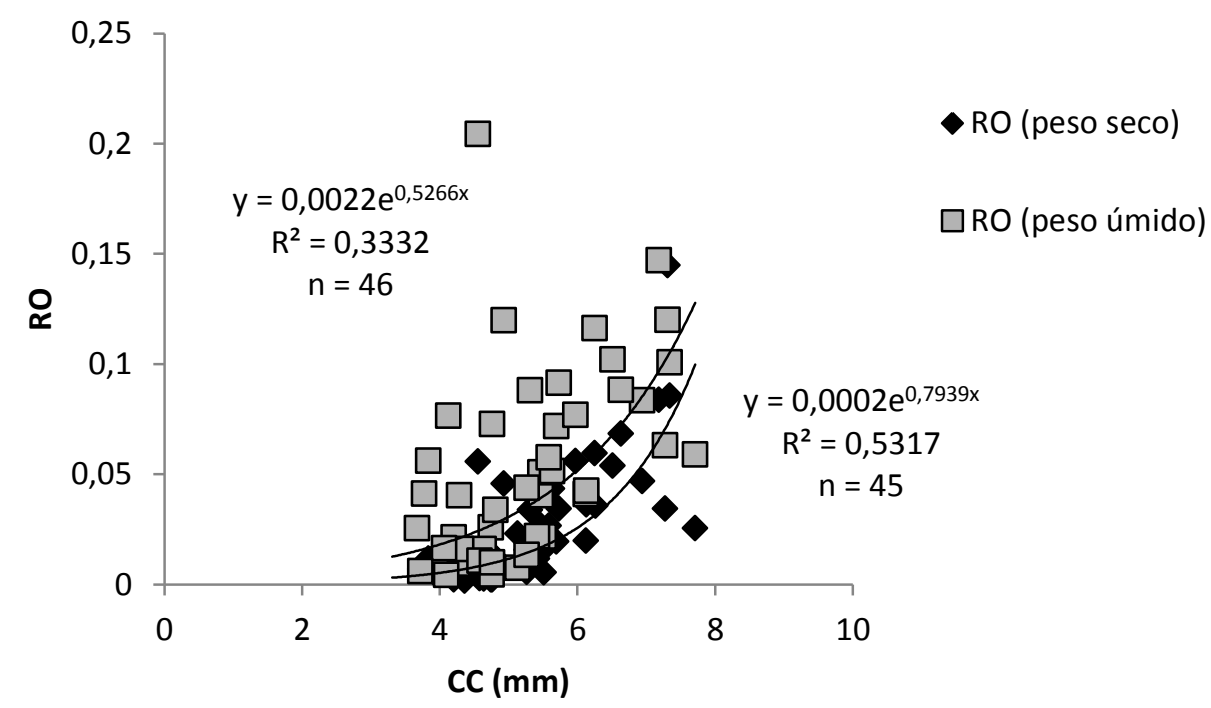

Figura 29: Regressão entre o investimento reprodutivo (RO) e o tamanho (CC) das fêmeas de Pachycheles monilifer simbiontes do briozoário Schizoporella errata calculado a partir dos pesos seco e úmido.

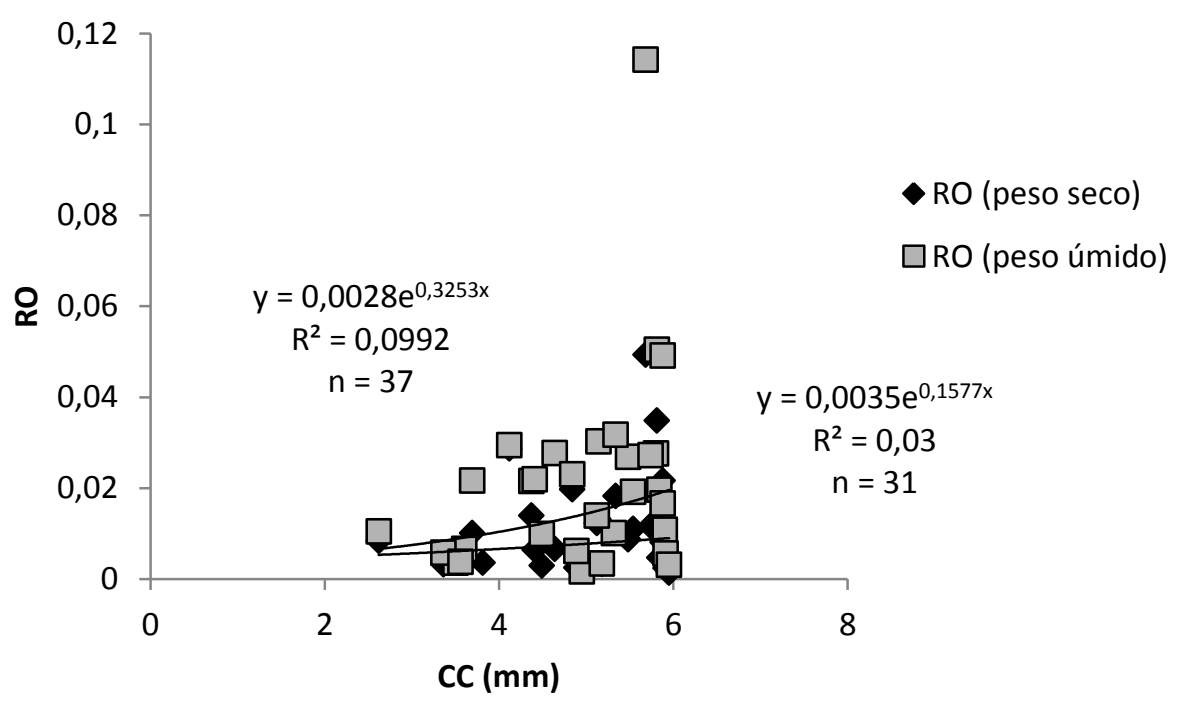

Figura 30: Regressão entre o investimento reprodutivo (RO) e o tamanho (CC) das fêmeas de Pachycheles monilifer simbiontes do poliqueto Phragmatopoma caudata calculado a partir dos pesos seco e úmido. 


\section{Variabilidade genética}

\section{Gene mitocondrial 16S}

Foram obtidas sequências do gene mitocondrial $16 \mathrm{~S}$ de 21 indivíduos da espécie $P$. monilifer, provenientes de praias de Ubatuba, São Vicente e São Sebastião e um indivíduo da Venezuela. Além dessas sequências, foram importadas do GenBank sequências de outras quatro espécies de Pachycheles para comparar a divergência genética.

O alinhamento das sequências consistiu cerca de 550 pares de bases. Porém, as sequências importadas do GenBank foram ligeiramente menores que as obtidas, com cerca de 510 pares de bases.

A taxa de divergência genética intraespecífica foi de 0 a $1 \%$, sendo que a divergência entre $P$. monilifer e outras espécies congenéricas oscilou entre 4,9 e 11,4\% (tabela 5). A maior divergência intraespecífica encontrada foi entre o exemplar proveniente da Venezuela com dois indivíduos de Ubatuba, um do píer do Itaguá e um da Ilha Anchieta. Os exemplares da praia Grande e do Itaguá, que são o foco desse estudo, mostraram a menor divergência entre os exemplares, variando de 0 a $0,4 \%$ (tabela 9) e permaneceram todos no mesmo ramo do dendograma (figura 31).

A espécie $P$. serratus foi a espécie que se mostrou mais distante geneticamente de $P$. monilifer, com uma taxa de divergência de $11,4 \%$ e a espécie mais próxima é a $P$. ackleianus com divergência de 4,9 a 5,1\%.

O dendograma gerado demonstra que embora o ramo formado por dois indivíduos da llha Anchieta estar bem suportado (75\% de bootstrap), o grupo da espécie $P$. monilifer não formou populações estruturadas, indicando a possibilidade de fluxo gênico entre as localidades amostradas, inclusive com o exemplar da Venezuela (figura 32). 
Tabela 5: Matriz de divergência genética da subunidade do gene mitocondrial $16 \mathrm{~S}$ das espécies Pachycheles monilifer, $P$ ackleianus, $P$. laevidactylus, $P$. spinidactylus e $P$. serratus (IT = píer do Itaguá, Ubatuba; GR = praia Grande, Ubatuba; ITAR = praia Itararé, São Vicente; LAZ = praia do Lázaro, Ubatuba, ANC = Iha Anchieta, Ubatuba; COU = Ilha das Couves, Ubatuba; VEN = Venezuela; ILHB = Ilhabela, São Sebastião; PRU = praia do Prumirim, Ubatuba).

\begin{tabular}{|c|c|c|c|c|c|c|c|c|c|c|c|c|c|c|c|c|c|c|c|c|c|c|c|c|c|c|}
\hline Espécimes & 1 & 2 & 3 & 4 & 5 & 6 & 7 & 8 & 9 & 10 & 11 & 12 & 13 & 14 & 15 & 16 & 17 & 18 & 19 & 20 & 21 & 22 & 23 & 24 & 25 & 26 \\
\hline 1P. monilifer IT & 0,00 & & & & & & & & & & & & & & & & & & & & & & & & & \\
\hline 2 P. monilifer IT & 0,21 & 0,00 & & & & & & & & & & & & & & & & & & & & & & & & \\
\hline 3P. monilifer IT & 0,21 & 0,43 & 0,00 & & & & & & & & & & & & & & & & & & & & & & & \\
\hline 4 P. monilifer IT & 0,21 & 0,00 & 0,43 & 0,00 & & & & & & & & & & & & & & & & & & & & & & \\
\hline 5 P. monilifer GR & 0,00 & 0,21 & 0,21 & 0,21 & 0,00 & & & & & & & & & & & & & & & & & & & & & \\
\hline 6P. monilifer GR & 0,00 & 0,21 & 0,21 & 0,21 & 0,00 & 0,00 & & & & & & & & & & & & & & & & & & & & \\
\hline 7 P. monilifer GR & 0,21 & 0,00 & 0,43 & 0,00 & 0,21 & 0,21 & 0,00 & & & & & & & & & & & & & & & & & & & \\
\hline 8P. monilifer GR & 0,21 & 0,00 & 0,43 & 0,00 & 0,21 & 0,21 & 0,00 & 0,00 & & & & & & & & & & & & & & & & & & \\
\hline 9 P. monilifer GR & 0,00 & 0,21 & 0,21 & 0,21 & 0,00 & 0,00 & 0,21 & 0,21 & 0,00 & & & & & & & & & & & & & & & & & \\
\hline 10 P. monilifer ITAR & 0,00 & 0,21 & 0,21 & 0,21 & 0,00 & 0,00 & 0,21 & 0,21 & 0,00 & 0,00 & & & & & & & & & & & & & & & & \\
\hline 11 P. monilifer LAZ & 0,21 & 0,00 & 0,43 & 0,00 & 0,21 & 0,21 & 0,00 & 0,00 & 0,21 & 0,21 & 0,00 & & & & & & & & & & & & & & & \\
\hline 12 P. monilifer ANC & 0,64 & 0,43 & 0,86 & 0,43 & 0,64 & 0,64 & 0,43 & 0,43 & 0,64 & 0,64 & 0,43 & 0,00 & & & & & & & & & & & & & & \\
\hline 13 P. monilifer ANC & 0,00 & 0,21 & 0,21 & 0,21 & 0,00 & 0,00 & 0,21 & 0,21 & 0,00 & 0,00 & 0,21 & 0,64 & 0,00 & & & & & & & & & & & & & \\
\hline 14 P. monilifer ANC & 0,64 & 0,43 & 0,86 & 0,43 & 0,64 & 0,64 & 0,43 & 0,43 & 0,64 & 0,64 & 0,43 & 0,00 & 0,64 & 0,00 & & & & & & & & & & & & \\
\hline 15 P. monilifer IT & 0,21 & 0,00 & 0,43 & 0,00 & 0,21 & 0,21 & 0,00 & 0,00 & 0,21 & 0,21 & 0,00 & 0,43 & 0,21 & 0,43 & 0,00 & & & & & & & & & & & \\
\hline 16 P. monilifer IT & 0,00 & 0,21 & 0,21 & 0,21 & 0,00 & 0,00 & 0,21 & 0,21 & 0,00 & 0,00 & 0,21 & 0,64 & 0,00 & 0,64 & 0,21 & 0,00 & & & & & & & & & & \\
\hline 17 P. monilifer GR & 0,00 & 0,21 & 0,21 & 0,21 & 0,00 & 0,00 & 0,21 & 0,21 & 0,00 & 0,00 & 0,21 & 0,64 & 0,00 & 0,64 & 0,21 & 0,00 & 0,00 & & & & & & & & & \\
\hline 18 P. monilifer GR & 0,00 & 0,21 & 0,21 & 0,21 & 0,00 & 0,00 & 0,21 & 0,21 & 0,00 & 0,00 & 0,21 & 0,64 & 0,00 & 0,64 & 0,21 & 0,00 & 0,00 & 0,00 & & & & & & & & \\
\hline 19 P. monilifer COU & 0,21 & 0,00 & 0,43 & 0,00 & 0,21 & 0,21 & 0,00 & 0,00 & 0,21 & 0,21 & 0,00 & 0,43 & 0,21 & 0,43 & 0,00 & 0,21 & 0,21 & 0,21 & 0,00 & & & & & & & \\
\hline 20 P. monilifer VEM & 0,86 & 0,64 & 1,08 & 0,64 & 0,86 & 0,86 & 0,64 & 0,64 & 0,86 & 0,86 & 0,64 & 1,08 & 0,86 & 1,08 & 0,64 & 0,86 & 0,86 & 0,86 & 0,64 & 0,00 & & & & & & \\
\hline 21 P. monilifer ILHB & 0,00 & 0,21 & 0,21 & 0,21 & 0,00 & 0,00 & 0,21 & 0,21 & 0,00 & 0,00 & 0,21 & 0,64 & 0,00 & 0,64 & 0,21 & 0,00 & 0,00 & 0,00 & 0,21 & 0,86 & 0,00 & & & & & \\
\hline 22 P. monilifer PRU & 0,21 & 0,00 & 0,43 & 0,00 & 0,21 & 0,21 & 0,00 & 0,00 & 0,21 & 0,21 & 0,00 & 0,43 & 0,21 & 0,43 & 0,00 & 0,21 & 0,21 & 0,21 & 0,00 & 0,64 & 0,21 & 0,00 & & & & \\
\hline 23 P. ackleianus & 4,92 & 5,17 & 5,17 & 5,17 & 4,92 & 4,92 & 5,17 & 5,17 & 4,92 & 4,92 & 5,17 & 5,15 & 4,92 & 5,15 & 5,17 & 4,92 & 4,92 & 4,92 & 5,17 & 5,21 & 4,92 & 5,17 & 0,00 & & & \\
\hline 24 P. laevidactylus & 5,77 & 5,51 & 6,03 & 5,51 & 5,77 & 5,77 & 5,51 & 5,51 & 5,77 & 5,77 & 5,51 & 5,49 & 5,77 & 5,49 & 5,51 & 5,77 & 5,77 & 5,77 & 5,51 & 6,08 & 5,77 & 5,51 & 5,49 & 0,00 & & \\
\hline 25 P. spinidactylus & 5,71 & 5,45 & 5,96 & 5,45 & 5,71 & 5,71 & 5,45 & 5,45 & 5,71 & 5,71 & 5,45 & 5,43 & 5,71 & 5,43 & 5,45 & 5,71 & 5,71 & 5,71 & 5,45 & 6,01 & 5,71 & 5,45 & 8,54 & 6,02 & 0,00 & \\
\hline 26 P. serratus & 11,39 & 11,39 & 11,07 & 11,39 & 11,39 & 11,39 & 11,39 & 11,39 & 11,39 & 11,39 & 11,39 & 11,34 & 11,39 & 11,34 & 11,39 & 11,39 & 11,39 & 11,39 & 11,39 & 11,32 & 11,39 & 11,39 & 11,12 & 11,80 & 14,56 & 0,00 \\
\hline
\end{tabular}




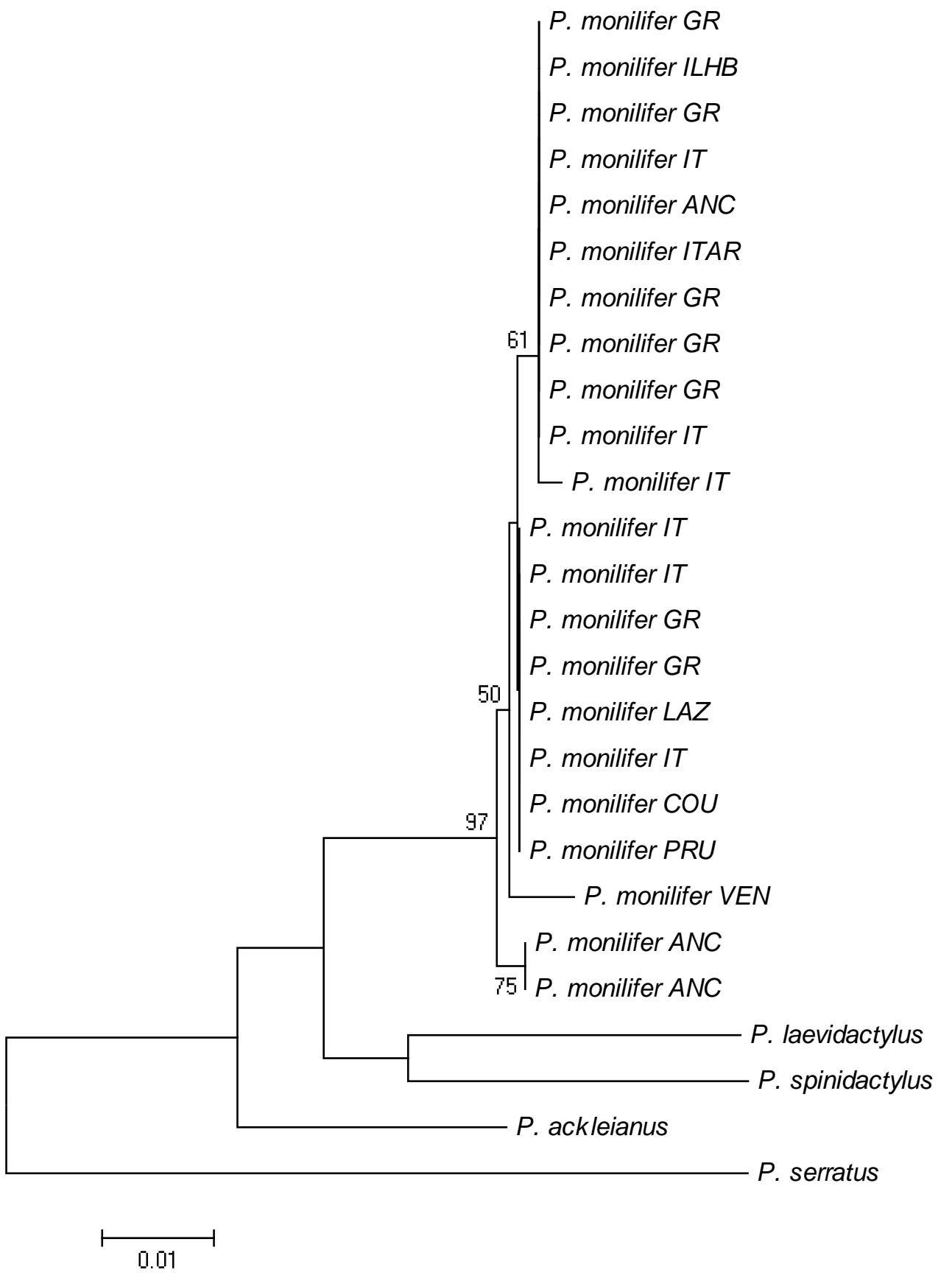

Figura 31: Dendograma baseado em método de distância por meio do algoritmo de Neighbor-Joining do gene mitocondrial 16S. Os números apresentados correspondem aos valores de significância para 1000 réplicas de bootstrap (GR = praia Grande, Ubatuba; ILHB = Ilhabela, São Sebastião; IT = píer do Itaguá, Ubatuba; ANC = Ilha Anchieta, Ubatuba; ITAR = praia Itararé, São Vicente; LAZ = praia do Lázaro, Ubatuba; $\mathrm{COU}=$ Ilha das Couves, Ubatuba; PRU = praia do Prumirim, Ubatuba; VEN = Venezuela). 


\section{Gene mitocondrial COI}

Para o gene mitocondrial COI foram obtidas 11 sequências de indivíduos de $P$. monilifer de quatro praias de Ubatuba (praia Grande, do Itaguá, Lázaro e Anchieta) e uma de São Sebastião (praia do Segredo), não sendo possível amplificar os fragmentos do gene COI dos outros indivíduos. Para a análise de distância genética foi incluída uma sequência parcial da espécie $P$. laevidactylus.

$\mathrm{O}$ alinhamento das sequências do gene mitocondrial COI consistiu em torno de 670 pares de bases. A taxa de divergência genética intraespecífica variou de 0 a $1 \%$, enquanto que a variação interespecífica foi muito maior, sendo registrada um valor de 13,5\%. A variação das bases entre os exemplares das praias em estudo (Itaguá e Grande) foi a menor e variou de 0 a $0,17 \%$. A maior divergência genética intraespecífica encontrada foi entre um exemplar da praia do Lázaro com um do Itaguá e um da Ilha Anchieta, sendo a divergência de 1\% (tabela 6).

$\mathrm{Na}$ figura 33, pode ser observado que nenhum haplótipo foi fixado em uma única população, sendo que também não houve estruturação dos ramos, sugerindo que há fluxo gênico entre os indivíduos amostrados. Embora o espécime da praia do Lázaro esteja bem suportado (88\% de bootstrap), foi amostrado apenas um indivíduo. 
Tabela 6: Matriz de divergência genética da subunidade do gene mitocondrial COI da espécie Pachycheles monilifer (IT = píer do Itaguá, Ubatuba; GR = praia Grande, Ubatuba; LAZ = praia do Lázaro, Ubatuba, ANC = llha Anchieta, Ubatuba; SEG = praia do Segredo, São Sebastião).

\begin{tabular}{|c|c|c|c|c|c|c|c|c|c|c|c|c|}
\hline Espécimes & 1 & 2 & 3 & 4 & 5 & 6 & 7 & 8 & 9 & 10 & 11 & 12 \\
\hline 1P. monilifer IT & 0,00 & & & & & & & & & & & \\
\hline 2P. monilifer IT & 0,17 & 0,00 & & & & & & & & & & \\
\hline 3P. monilifer IT & 0,00 & 0,17 & 0,00 & & & & & & & & & \\
\hline 4P. monilifer GR & 0,00 & 0,17 & 0,00 & 0,00 & & & & & & & & \\
\hline 5 P. monilifer GR & 0,00 & 0,17 & 0,00 & 0,00 & 0,00 & & & & & & & \\
\hline 6P. monilifer GR & 0,00 & 0,17 & 0,00 & 0,00 & 0,00 & 0,00 & & & & & & \\
\hline 7P. monilifer GR & 0,00 & 0,17 & 0,00 & 0,00 & 0,00 & 0,00 & 0,00 & & & & & \\
\hline 8P. monilifer LAZ & 0,85 & 1,02 & 0,85 & 0,85 & 0,85 & 0,85 & 0,85 & 0,00 & & & & \\
\hline 9 P. monilifer $\mathrm{ANCH}$ & 0,17 & 0,34 & 0,17 & 0,17 & 0,17 & 0,17 & 0,17 & 1,02 & 0,00 & & & \\
\hline 10 P. monilifer GR & 0,00 & 0,17 & 0,00 & 0,00 & 0,00 & 0,00 & 0,00 & 0,85 & 0,17 & 0,00 & & \\
\hline $11 P$. monilifer SEG & 0,00 & 0,17 & 0,00 & 0,00 & 0,00 & 0,00 & 0,00 & 0,85 & 0,17 & 0,00 & 0,00 & \\
\hline 12 P. laevidactylus & 13,54 & 13,54 & 13,54 & 13,54 & 13,54 & 13,54 & 13,54 & 13,37 & 13,71 & 13,54 & 13,54 & 0,00 \\
\hline
\end{tabular}




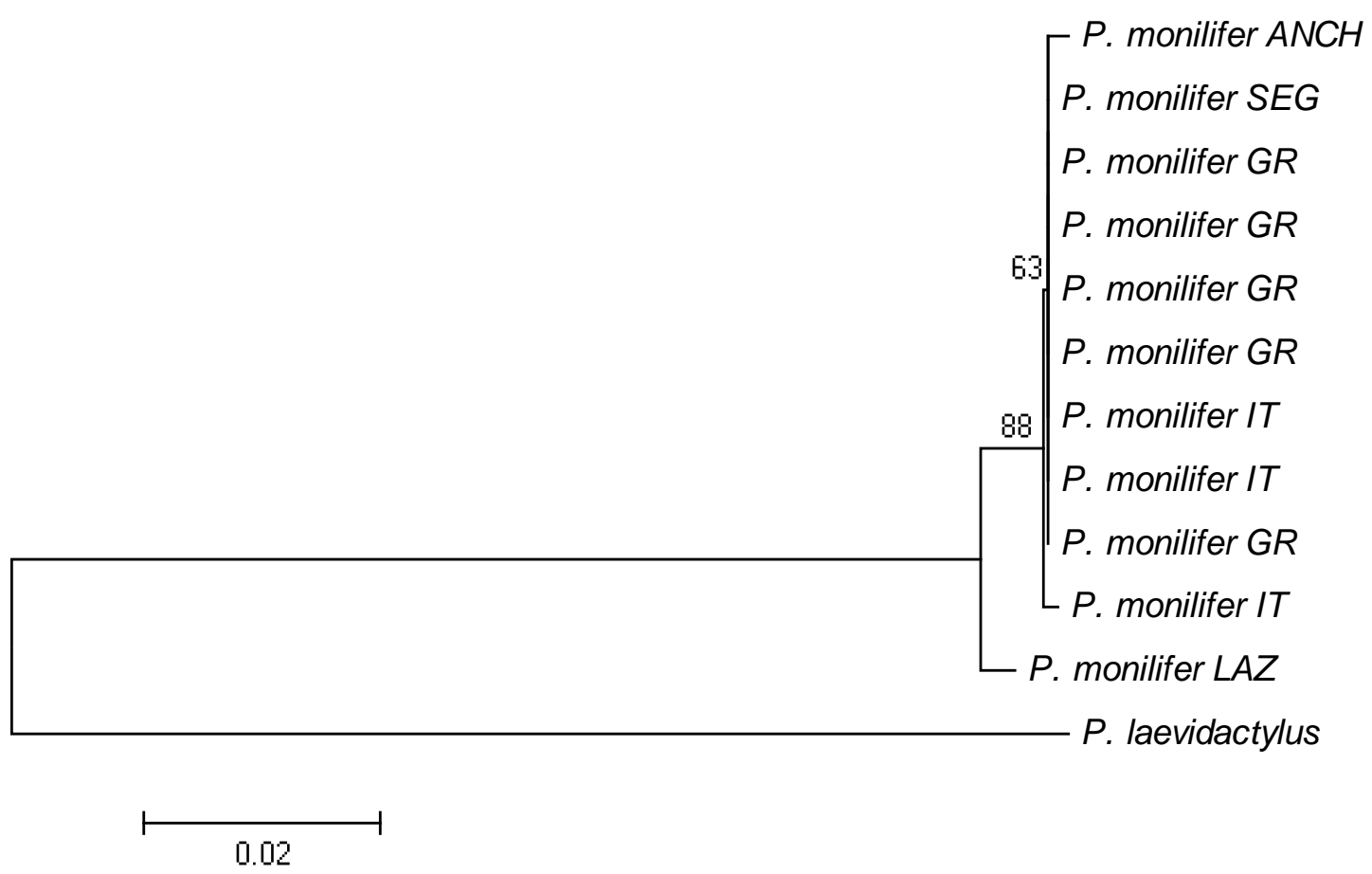

Figura 33: Dendograma baseado em método de distância por meio do algoritmo de Neighbor-Joining do gene mitocondrial COI. Os números apresentados correspondem aos valores de significância para 1000 réplicas de bootstrap $(\mathrm{ANCH}=$ Ilha Anchieta; SEG = praia do Segredo, São Sebastião; GR = praia Grande, Ubatuba; IT = píer do Itaguá, Ubatuba; Ubatuba; LAZ = praia do Lázaro, Ubatuba).

Foram geradas redes de haplótipos a partir do método estatístico de parcimônia no TCS (dado não apresentado) e pelo método Median-Joining no Network (figura 34) sendo que ambos forneceram o mesmo resultado. Baseados nos fragmentos parciais do gene mitocondrial $\mathrm{COI}$ foram obtidos quatro haplótipos, com a diversidade haplotípica de $0,49 \%$ entre os indivíduos. Dos quatro haplótipos encontrados, três representam haplótipos individuais e um compartilhado. O haplótipo com maior frequência de indivíduos $(\mathrm{H} 1)$ inclui dois indivíduos da píer do Itaguá, cinco da praia Grande e um da praia do Segredo. Já os haplótipos individuais são representados por um indivíduo da píer do Itaguá (H2), um do Lázaro (H3) e um da Ilha Anchieta (H4). A maior divergência haplotípica encontrada foi do indivíduo da praia do Lázaro, envolvendo cinco passos mutacionais. 
A análise de divergência molecular (AMOVA) indicou que entre as populações do píer do Itaguá e da praia Grande a variação haplotípica é $18,9 \%$, sendo que a divergência dentro dessas populações foi maior $(81,1 \%)$, porém tais diferenças não são significativas $(p=0,39)$.

A nível intrapopulacional os indivíduos do píer do Itaguá apresentaram uma divergência haplotípica de $0,66 \pm 0,31 \%$, enquanto não houve divergência entre os indivíduos da praia Grande.

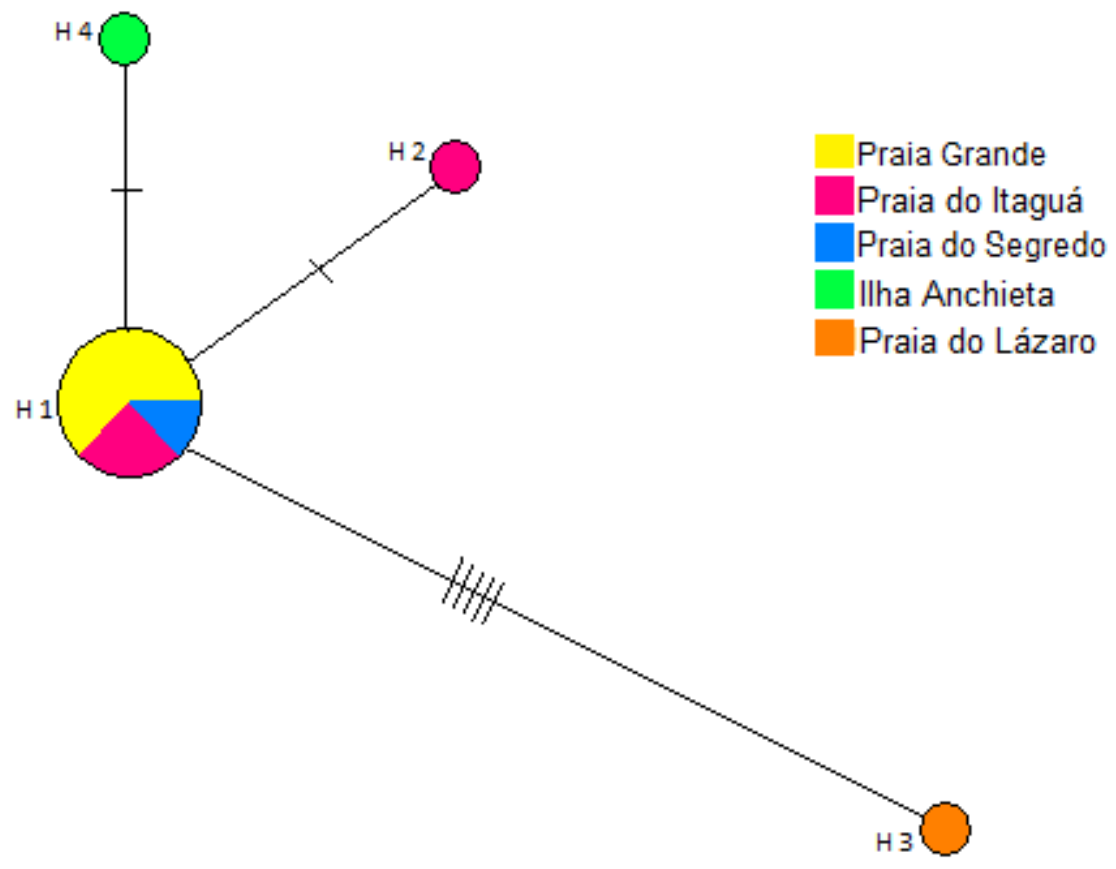

Figura 34: Rede de haplótipos construída pelo método de Median-Joining, indicando a distribuição dos quatro haplótipos identificados nos 11 espécimes de Pachycheles monilifer. $\mathrm{O}$ número abaixo do círculo corresponde ao número do haplótipo $(\mathrm{H})$. $\mathrm{O}$ tamanho do círculo é proporcional à frequência do haplótipo. Cada traço representa um passo mutacional. 
Os dados genéticos obtidos a partir de sequências parciais dos genes mitocondriais $16 \mathrm{~S}$ e $\mathrm{COI}$ nos permitem afirmar que a espécie em estudo trata-se de uma única espécie e apresenta fluxo gênico entre as localidades amostradas. As análises de distância mostraram que a divergência genética intraespecífica das sequências do gene $16 \mathrm{~S}$ foi muito baixa e menor que a divergência interespecífica. No trabalho de Mantelatto et al. (2011) foi encontrada uma divergência intraespecífica para a espécie de porcelanídeo Petrolisthes tridentatus de 0 a 5,7\%, evidenciando que a diferenciação encontrada no presente trabalho é baixa. Entre as sequências do gene COI a divergência foi abaixo de 1\%, sendo esse gene menos conservado e com uma alta taxa mutacional, esse resultado indica que a variação entre as localidades é mínima e quase inexistente.

A divergência haplotípica entre os grupos da praia Grande e Itaguá é devido à diferenciação de apenas um exemplar que possui um haplótipo individual, podendo ser devido ao baixo $\mathrm{n}$ amostral e uma amostra maior provavelmente diminuiria a divergência haplotípica entre os grupos. Os outros exemplares possuem um haplótipo compartilhado, confirmando um fluxo gênico contínuo com a reduzida possibilidade de diferenciação genética (Slatkin, 1987). A existência de fluxo gênico entre essas localidades é condizente, já que são muito próximas geograficamente.

Sobre os indivíduos da praia do Lázaro e da llha Anchieta nada pode ser inferido, já que ambas as localidades estão representadas apenas por um indivíduo, entretanto nota-se que o exemplar da praia do Lázaro é o mais distante geneticamente.

Os resultados moleculares confirmaram que a espécie Pachycheles monilifer tem um eficiente mecanismo de dispersão, não havendo diferenças genéticas significativas entre os organismos provenientes das diferentes localidades. Assim, as diferenças ecológicas encontradas entre as duas populações estudadas parece estar ligada às características fenotípicas, não sendo os fatores genéticos decisivos para as diferenças reprodutivas detectadas nas localidades estudadas

A variação de tamanho encontrada para a espécie Pachycheles monilifer nas praias de Ubatuba corrobora com o registrado na literatura para a mesma região (Fransozo \& Bertini, 2001). A maturidade sexual da espécie registrada no presente estudo foi menor $(2,6 \mathrm{~mm})$ que a reportada na literatura $(3,3 \mathrm{~mm})$ (Fransozo \& Bertini, 2001; Hattori \& Pinheiro, 2001), com a presença de cinco fêmeas ovígeras abaixo do referido tamanho indicando uma maturidade precoce. Não houve dimorfismo sexual, já que entre os machos $\mathrm{e}$ as fêmeas não foi registrada diferenças em relação ao tamanho, corroborando com o trabalho de Fransozo \& Bertini (2001). As duas 
populações em estudo mostraram estar em equilíbrio devido à proporção sexual registrada.

A diferença de tamanho encontrada entre as fêmeas ovígeras e não ovígeras em ambos os substratos pode estar relacionada à abundância de cada uma nas classes de tamanho, já que as fêmeas ovígeras estão presentes em maior frequência na população.

O maior tamanho dos caranguejos simbiontes do briozoário pode estar relacionada à disponibilidade de espaço nas colônias. A distribuição de tamanho dos indivíduos simbiontes do briozoário é mais uniforme e abrangente. Segundo Osman \& Haugsness (1980), o espaço é um recurso limitante em uma população, sendo mais evidente em comunidades de invertebrados marinhos sésseis. Por não possuírem capacidade escavadora, os porcelanídeos simbiontes do poliqueto vivem em fendas e galerias que são abertas por outros caranguejos predadores da colônia (Gore et al, 1978), o que impõe determinada restrição de deslocamento, além da limitação de espaço imposto pela própria colônia. As espécies Menippe nodrifrins, Eriphia gonagra, Pachygrapsus gracilis entre outras são habitantes frequentes dessa colônia e podem agir dessa forma (Mantelatto, comunicação pessoal). Já a colônia do briozoário é desenhada por ramos eretos, ramificados e entrelaçados, permitindo caranguejos de baixo porte se deslocarem com maior mobilidade nesse ambiente. O espaço na colônia do briozoário não parece ser um fator limitante, embora os caranguejos também habitem porções mais internas da colônia (Morgado, 1980; Cocito et al., 2000).

O tamanho de uma população e também dos indivíduos inseridos nela são limitados pela complexidade estrutural do habitat (Beck, 1995). Diferenças na distribuição de tamanho encontradas em lagostas europeias em diversos habitats foram relacionadas ao tipo de refúgio (toca) ocupado pelos organismos (Howard, 1980). A ação limitante do substrato a apenas uma classe de tamanho pode limitar a produção da população por meio da mortalidade, emigração ou 'nanismo' na classe afetada (Caddy, 1986; Caddy \& Stamatopoulas, 1990). Assim, o tamanho dos caranguejos pode estar relacionado ao espaço disponível da colônia ocupada.

Outro fator também relacionado ao crescimento é a oferta de alimento, a qual parece ser mais escassa no substrato do poliqueto devido aos períodos diários de exposição à maré baixa. Os porcelanídeos são primariamente filtradores e utilizam o terceiro maxilípodo para aquisição de nutrientes (Gore et al., 1978; Kropp, 1981), podendo ser prejudicados durante esses períodos de exposição. Durante as coletas, foi observada a ausência do caranguejo nas colônias localizadas acima da zona intertidal, refletindo sua relativa dependência da água. Segundo Brody (1991), a 
flutuação ou escassez de alimento pode prejudicar o crescimento e reprodução dos organismos. Embora possa coletar detritos na ausência de água circulante, é muito mais vantajoso se alimentar por filtração da água (Kropp, 1981).

Durante a estação chuvosa os indivíduos simbiontes do poliqueto são maiores podendo estar relacionado às chuvas constantes durante esse período que acabam carreando nutrientes para a colônia. Além das chuvas, nesse período a região recebe a corrente oceânica ACAS (Água Central do Atlântico Sul), caracterizada por massas de águas frias e pelo transporte de grande quantidade de nutrientes (Castro-Filho et al., 1987). Segundo Berkenbusch \& Rowden (2000), a disponibilidade de alimento se mostrou um fator mais importante do que a temperatura no crescimento das populações de Calianassa filholi, fato também confirmado na população de Petrolisthes elongatus por Jones (1977). Entretanto, os indivíduos associados ao briozoário não apresentam diferença de tamanho entre as estações do ano, mostrando que não são diretamente afetados pela sazonalidade, ciclo de marés ou pelas correntes, mantendo certa estabilidade ao longo do ano.

Segundo Jensen (1958) apud Somers (1991), o tamanho do corpo da fêmea influencia o número relativo de embriões que podem ser produzidos, mas são os fatores ambientais que afetam o número absoluto. Porém, no trabalho de Hattori \& Pinheiro (2001), devido à baixa variação da temperatura e fotoperíodo na região de Ubatuba, a fecundidade e a porcentagem de fêmeas ovígeras não apresentaram relação com essas variáveis. Outros trabalhos relatam homogeneidade de temperatura na região, inclusive uma média anual constante em torno dos 24ํㅡ desde 1988 até os tempos atuais (Negreiros-Fransozo et al.,1991; Mantelatto \& Souza-Carrey, 1998; Fransozo \& Bertini, 2001; Hattori \& Pinheiro, 2001; Terossi \& Mantelatto, 2010; Peiró, 2012; Carvalho-Batista, 2013). Além da temperatura, estudos revelam que as Baías de Ubatuba, do Flamengo e da Fortaleza possuem condições ambientais muito similares (Abreu, 1980; Negreiros-Fransozo et al., 1991; Mantelatto \& Fransozo, 1999), evidenciando certa homogeneidade na região. Assim, acredita-se que devido a tais similaridades e à proximidade geográfica entre as praias, ambos os substratos estudados estejam sob as mesmas condições ambientais. Além disso, a região de Ubatuba e todo o litoral do sudeste do Brasil estão sob a influência das mesmas massas de água durante todo o ano, sendo a mais conhecida a Água Central do Atlântico Sul (ACAS) e as massas Água Tropical e Água Costeira (Castro-Filho et al., 1987).

A quantidade de matéria orgânica disponível no ambiente, além de afetar 0 crescimento, tem influência direta nos aspectos reprodutivos de uma espécie (Chester, 1996). O substrato do briozoário está inserido na baía de Ubatuba e, apesar de 
possuir um grande aporte de nutrientes devido à existência da atividade antrópica e pesqueira e ser uma área protegida, essa baía possui intensa circulação de água (Mantelatto \& Fransozo, 1999). A praia Grande, onde estão situadas as colônias do poliqueto, é um local muito impactado pelo turismo local e a circulação da água é mais intensa, por ser uma praia exposta com alto hidrodinamismo.

Nos crustáceos a fecundidade constitui um parâmetro de grande importância na determinação do potencial reprodutivo e do estoque de uma população, podendo evidenciar adaptações reprodutivas às condições ambientais (Sastry, 1983; Mantelatto \& Fransozo, 1997). O maior fitness reprodutivo das fêmeas simbiontes do briozoário é uma resposta às condições estabelecidas devido à interação entre substrato ocupado e tamanho adquirido. Como essas fêmeas são maiores, também são capazes de produzir mais embriões, possuindo uma fecundidade quase três vezes maior.

Os dois grupos de fêmeas mostraram uma relação positiva entre fecundidade e tamanho, porém as fêmeas simbiontes do poliqueto, principalmente as maiores, apresentaram uma grande plasticidade em relação à produção dos embriões. As fêmeas pertencentes à maior classe de tamanho apresentaram uma fecundidade média menor que as menores fêmeas. Segundo Shakuntala (1977) e Kinne (1961), a baixa fecundidade em fêmeas grandes é associada à senescência, assim fêmeas maiores, geralmente mais velhas, apresentam menor fecundidade que as fêmeas menores e mais jovens. Porém, esse resultado encontrado pode ser devido ao baixo $n$ amostral da última classe de tamanho $(n=3)$, já que o mesmo padrão não foi encontrado nas fêmeas simbiontes do briozoário. Ainda assim, observou-se uma grande variação da fecundidade nessas fêmeas podendo ser devido aos períodos de maré baixa com consequente menor oferta de alimento e ao alto hidrodinamismo na colônia do poliqueto, apesar desta funcionar como uma barreira física. Segundo Harisson (1990), uma nutrição parental deficiente durante o período reprodutivo pode resultar em baixa fecundidade e embriões menores, além de prejudicar a qualidade e fertilidade dos embriões.

Dentre os crustáceos, os caranguejos porcelanídeos são animais pequenos e apresentam uma fecundidade relativamente baixa em relação, por exemplo, aos braquiúros que chegam a produzir um número muito grande de embriões (Reid \& Corey 1991; Branco \& Avilar, 1992; Mantelatto \& Fransozo, 1997; Leme \& NegreirosFransozo, 1998; Brante et al., 2003). A fecundidade registrada no presente estudo se diferenciou dos trabalhos realizados com a mesma espécie ou com espécies congenéricas (Reid \& Corey, 1991; Pinheiro \& Fransozo, 1995; Hattori \& Pinheiro, 2001) e demonstrou produzir menos embriões que outras espécies de porcelanídeo 
(tabela 7) (Reid \& Corey, 1991; López et al., 1997; Hernáez \& Palma, 2003; Wehrtmann et al., 2011).

Tabela 7: Relação do tamanho e de fecundidade média de algumas espécies do gênero Pachycheles registrados na literatura e também do presente trabalho (EUA = Estados Unidos da América; BR = Brasil).

\begin{tabular}{l|c|c|c|c}
\hline \multicolumn{1}{c|}{ Espécie } & $\begin{array}{c}\text { CC (mm) } \\
\mathbf{X}(\mathbf{m i ́ n}-\mathbf{m a ́ x )}\end{array}$ & Fecundidade & Local & Referência \\
\hline P. ackleianus & $3,7(2,8-4,3)$ & 62,7 & Flórida (EUA) & Reid \& Corey (1991) \\
\hline P. laevidactylus & $6,4(3,3-9,6)$ & 156,1 & Praia Grande, Ubatuba, SP (BR) & Pinheiro \& Fransozo (1995) \\
\hline \multirow{4}{*}{\begin{tabular}{c} 
P. monilifer \\
\cline { 1 - 5 }
\end{tabular}} & $6,0(4,2-8,2)$ & 113,3 & Florida (EUA) & Reid \& Corey (1991) \\
\cline { 2 - 6 } & $6,1(3,3-8,8)$ & 135 & Praia Grande, Ubatuba, SP (BR) & Hattori \& Pinheiro (2001) \\
\cline { 2 - 5 } & $4,7(2,6-5,9)$ & 53,6 & Praia Grande, Ubatuba, SP (BR) & presente estudo \\
\cline { 2 - 5 } & $5,4(3,3-8,5)$ & 174 & Píer do Itaguá, Ubatuba, SP (BR) & presente estudo \\
\hline P. rugimanus & $4,2(3,2-5,9)$ & 94,2 & Florida (EUA) & Reid \& Corey (1991) \\
\hline \hline
\end{tabular}

No trabalho de Hattori \& Pinheiro (2001), também realizado no substrato do poliqueto na praia Grande, foram registradas fêmeas ovígeras de tamanho médio maior que as do presente trabalho. A ausência de exemplares maiores no presente trabalho pode ser devido ao tempo decorrido desde o trabalho feito por esses autores (mais de 15 anos) e considerando que a praia Grande é muito impactada, tais fatores podem interferir no ambiente e consequentemente na população de $P$. monilifer. Tais fêmeas ovígeras, além de serem maiores também apresentam maior fecundidade.

Segundo Reid \& Corey (1991), há uma forte relação entre o tamanho da carapaça e a fecundidade, assim espera-se que as maiores fêmeas também apresentem maiores fecundidades. Entretanto, fica evidente a influência do tipo de substrato na produção de embriões quando comparamos as fêmeas ovígeras do presente estudo simbiontes do briozoário com as registradas pelos autores Hattori \& Pinheiro (2001). As fêmeas ovígeras simbiontes do briozoário são em média menores que as registradas por esses autores, porém apresentam maior fecundidade. Assim, fêmeas simbiontes do briozoário e do poliqueto, mesmo sendo do mesmo tamanho, apresentam uma fecundidade diferente, evidenciando a importância do tipo de substrato ocupado na produção de embriões e não somente a influência do tamanho do indivíduo. 
Nota-se que em relação ao tamanho, as fêmeas ovígeras simbiontes do briozoário do píer do Itaguá são menores que as fêmeas da mesma espécie do mar da Florida (Reid \& Corey, 1991), porém com maior fecundidade. As fêmeas ovígeras simbiontes do briozoário, apesar de não serem os maiores exemplares registrados na literatura, são as que apresentam maior fecundidade, inclusive dentre outras espécies de Pachycheles (Ogawa \& Rocha, 1976; Reid \& Corey, 1991; Pinheiro \& Fransozo, 1995; Hattori \& Pinheiro, 2001).

Nas espécies que possuem desenvolvimento planctônico os embriões constituem a única forma de investimento parental na reprodução, sendo o tamanho do embrião um importante parâmetro da história de vida de invertebrados marinhos (Lessios, 1990). Nos crustáceos, geralmente os maiores embriões possuem mais energia destinada ao desenvolvimento da futura larva, resultando na diminuição do número de estágios larvais e, consequentemente, uma permanência mais abreviada no plâncton (Lindley, 1990; Pinheiro et al., 1994).

Embora fatores genéticos e fisiológicos sejam responsáveis pela produção e variação do tamanho dos embriões, são as condições de temperatura, salinidade, disponibilidade de alimento e também o tipo de habitat que atuam como fatores importantes no desenvolvimento e modelagem dos mesmos (Thorson, 1950; Efford, 1969; Sastry, 1983; Clarke, 1988). Segundo Bas \& Spivak (2000), durante o início do desenvolvimento do embrião a membrana externa ainda não está completamente formada e a salinidade pode interferir no tamanho e volume através do controle osmótico. Dessa forma, as diferenças entre populações podem ser consequências de padrões evolutivos ligados às condições ambientais (Laptikhovsky, 2006). O tamanho e volume dos embriões das fêmeas de ambos os substratos estudados pode ser uma evidência que estão sob as mesmas condições ambientais, já que não foram encontradas diferenças em relação a esses parâmetros.

Comparações intraespecíficas com as fêmeas do mar da Florida (Reid \& Corey, 1991) revelam que os embriões do presente estudo são menores. O tamanho dos embriões é um caráter espécie-específico, mas pode ser variável entre as populações dependendo do tamanho da fêmea, do período reprodutivo e, principalmente, da temperatura, não sendo assim um carácter estritamente genético (Laptikhovsky, 2006). Segundo Kasyanov (1999) apud Laptikhovsky (2006), a relação entre fecundidade e tamanho dos embriões é inversamente proporcional devido à energia investida na reprodução ser limitada, resultando num balanço entre quantidade e qualidade. Isso fica evidente quando comparamos as fêmeas simbiontes do briozoário com as fêmeas da Flórida, as primeiras possuem maior fecundidade, porém produzem embriões menores. 
Um dos aspectos mais interessantes para o estudo da biologia reprodutiva em crustáceos é o investimento energético das fêmeas na reprodução (Hernáez \& Palma, 2003). Muitos trabalhos têm sido desenvolvidos a fim de medir tal energia destinada à produção de embriões (Brody, 1991; Hernàez \& Palma, 2003; Hernàez-Bove \& Pinheiro, 2001; Pavanelli et al., 2008; Wehrtmann et al., 2011).

As diferentes metodologias testadas para o cálculo de investimento reprodutivo (pesos úmido e seco) mostraram que o método utilizando o peso úmido é menos preciso, pois não é possível retirar a quantidade exata de água de todas as fêmeas e das massas de embriões, o que acaba interferindo no resultado. Assim, para o cálculo de investimento reprodutivo de uma espécie é aconselhável utilizar apenas o peso seco dos organismos, sendo este método de maior confiabilidade.

Assim como a fecundidade, espera-se que o investimento reprodutivo seja proporcional ao tamanho da fêmea, com fêmeas maiores destinando mais energia à produção dos embriões. (Hines, 1982, 1988; Hernàez \& Palma, 2003; Thiel \& Duffy, 2007). Entretanto essa relação só é observada quando há um grande aumento da fecundidade entre as classes de tamanho elevando o peso da massa de embriões. Nas fêmeas simbiontes do poliqueto não foi observada relação entre tamanho das fêmeas e investimento reprodutivo devido à pouca diferença existente da fecundidade entre as classes de tamanho. Já as fêmeas simbiontes do briozoário demonstraram uma crescente fecundidade ao longo das classes de tamanho, alocando mais energia na produção de embriões à medida que crescem.

A relação entre tamanho da fêmea e investimento reprodutivo vem sendo muito discutida, pois cada espécie e/ou população se comporta de maneira diferente. Em alguns trabalhos não foi registrada nenhuma relação entre tamanho e investimento reprodutivo (Wehrtmann \& Andrade, 1998; Wehrtmann et al., 2011) e para uma espécie de Hippolytidae essa relação se mostrou negativa (Terossi et al., 2010). As fêmeas simbiontes do briozoário mostraram relação positiva, pois um pequeno aumento de tamanho da fêmea resulta num grande aumento de fecundidade com, consequente, aumento do RO. Por outro lado, nas fêmeas simbiontes do poliqueto não foi registrada a mesma relação, podendo ser reflexo da pequena diferença de fecundidade entre as classes de tamanho.

O investimento reprodutivo da espécie $P$. monilifer da região de Ubatuba registrado no presente trabalho ( $2 \%$ do peso corporal da fêmea) se mostrou inferior aos valores reportados na literatura para outras espécies de Decapoda (Hines, 1991, 1992; Hernàez \& Palma, 2003; Miranda et al., 2006; Torati \& Mantelatto, 2008). Devido ao seu modo de vida simbionte com oferta de abrigo, proteção contra predadores e alimento disponível, esperava-se que essa espécie apresentasse um alto investimento 
reprodutivo. Porém, o baixo valor de $\mathrm{RO}$ encontrado pode indicar que o modo de vida não é o único fator que influencia no fitness reprodutivo. A espécie $P$. monilifer apresenta quelípodos muito robustos em relação a sua estrutura corporal, o que acaba elevando muito seu peso em relação à massa de embriões.

Dentre as espécies de Anomura existe uma grande variação de investimento reprodutivo. Por exemplo, em Dardanus insignis o investimento energético foi de $54 \%$ e em Loxopagurus loxochelis 6,8\% (Miranda et al., 2006; Torati \& Mantelatto, 2008). Apesar de $P$. monilifer ter apresentado um baixo $\mathrm{RO}$, corrobora com outras espécies de Porcellanidae de áreas temperadas que investem cerca de $5 \%$ ou menos na reprodução (Lardies \& Wehrtmann 1996; Hernáez-Bové 2001; Hernáez \& Palma 2003) e indivíduos de áreas tropicais podem apresentar RO abaixo dos 3\% (Wehrtmann et al., 2011). Na tabela 8 estão representados valores de investimento reprodutivo (RO) para espécies algumas de Porcellanidae reportados na literatura.

Tabela 8: Relação de valores de investimento reprodutivo $(\mathrm{RO})$ de diversas espécies de família Porcellanidae.

\begin{tabular}{cccc}
\hline Espécie & RO (\%) & Localidade & Referência \\
\hline Allopetrolisthes spinifrons & 2,4 & Norte do Chile & Hernáez-Bové \& Pinheiro 2001 \\
\hline Allopetrolisthes angulosus & 3,7 & Norte do Chile & Hernáez \& Palma 2003 \\
\hline Liopetrolisthes patagonicus & 7,4 & Norte do Chile & Hernáez \& Palma 2003 \\
\hline Pachycheles monilifer & 1,1 & Brasil (Ubatuba/SP, praia Grande) & Presente trabalho \\
\hline Pachycheles monilifer & 2,7 & Brasil (Ubatuba/SP, píer do ltaguá) & Presente trabalho \\
\hline Petrolisthes violaceus & 2,0 & Norte do Chile & Hernáez-Bové \& Pinheiro 2001 \\
\hline Petrolisthes armatus & 3,1 & Brasil (São Sebastião) & Wehrtmann et al. 2011 \\
\hline
\end{tabular}

Em geral, o investimento reprodutivo de decápodes na produção dos embriões é cerca de $10 \%$ do peso da fêmea, podendo variar de 3 a 23\% (Hines, 1991, 1992; Hernàez \& Palma, 2003; Miranda et al., 2006; Torati \& Mantelatto, 2008). Por outro lado, há espécies de pinoterídeos simbiontes parasitas que possuem um investimento reprodutivo extremamente alto (66 e 96\%) (Hines, 1992), sendo que os aspectos fisiológicos e ecológicos diferenciados dessas espécies são responsáveis por tal investimento. Ambas as espécies são simbiontes obrigatórias de bivalves e vivem na cavidade do manto de seus hospedeiros. Desse modo, as espécies são providas de uma carapaça com calcificação reduzida, com consequente redução do seu peso corporal, além de possuírem ovários grandes que permitem maior acúmulo de vitelo em relação a outras espécies (Hines, 1992). Este autor associou o alto investimento 
na produção de embriões à uma possível alta taxa de mortalidade larval precedendo o assentamento, já que esses caranguejos possuem alta especificidade de substrato.

Trabalhos realizados com o desenvolvimento larval com uma das espécies, também estudada por Hines (1992), confirmaram uma alta taxa de mortalidade larval e também dos primeiros estágio do caranguejo antes de encontrar o hospedeiro (Sandoz \& Hopkins, 1947; Sandifer, 1972). Em contrapartida, a espécie $P$. monilifer demostrou um baixo investimento reprodutivo e uma alta taxa de sobrevivência larval (Gore, 1973). Assim, o baixo RO da espécie em estudo e de outros porcelanídeos pode estar relacionado ao sucesso larval com melhores oportunidades de assentamento, já que vivem associados a uma série de substratos, demostrando uma baixa especificidade de habitat. Nesse sentido, o RO parece estar ligado à história de vida da espécie, envolvendo estratégias de sobrevivência e de adaptação e não somente a fatores genéticos.

O investimento reprodutivo das fêmeas em estudo é resultado da interação entre tamanho da fêmea e o tipo de substrato ocupado. As fêmeas simbiontes de ambos os substratos, além de apresentarem diferenças de crescimento e fecundidade, também demonstraram capacidade distinta em relação ao investimento energético para produção dos embriões. As fêmeas simbiontes do briozoário investiram cerca de duas vezes e meia mais energia na reprodução, tendo a habilidade de crescer mais e produzir mais embriões evidenciando o menor estresse reprodutivo oferecido por esse substrato.

Diferentes estruturas sociais e comportamentais são esperadas dos organismos simbiontes em resposta aos diferentes substratos ocupados (Thiel \& Baeza, 2001). Segundo Nelson (1962), a natureza do substrato é uma variável ecológica que exerce influência semelhante àquelas já conhecidas, como temperatura, salidade, luz, disponibilidade de alimento. Portanto, a diferença de RO está relacionada ao substrato que cada população habita, já que apresentam características morfológicas e ecológicas particulares que os tornam ambientes únicos. Gore et al. (1978) afirmou que a colônia do poliqueto representa um sítio potencial para a proteção e abrigo de várias espécies de crustáceos, além da oferta de alimento e um ambiente mais estável que o meio externo, já que atua como uma barreira contra o alto hidrodinamismo. Entretanto, muitas partículas de areia foram encontradas no conteúdo estomacal da espécie $P$. monilifer refletindo as condições de turbulência nesse ambiente (Gore et al., 1978). Isso evidencia certa instabilidade dentro da colônia, podendo prejudicar o desenvolvimento dos organismos. Por outro lado, a colônia do briozoário se mostra um ambiente fisicamente mais estável e de menor estresse para seus simbiontes, que habitam câmaras mais internas ou o interior 
dos túbulos (Cocito et al., 2000). Além da disponibilidade de alimento nesse ambiente ser maior em relação à colônia do poliqueto que passa por períodos diários de maré baixa enquanto que, o habitat do briozoário parece não sofrer influência da sazonalidade e ciclo de marés. Bosa \& Masunari (2002) classificaram o substrato do poliqueto como 'uma alternativa de colonização da assembleia de decápodos' justificando a maior diversidade de espécies reportada numa praia rochosa, onde os organismos encontram mais proteção e abrigo (Masunari et al., 1998).

Thiel et al. (2003) reportaram o comportamento de uma espécie de porcelanídeo em relação ao uso do substrato, na qual a espécie demonstra fidelidade às anêmonas de águas subtidais, porém tendem a mudar de hospedeiro em áreas intermareais. Tal comportamento revela que habitats intermareais podem não ser muito favoráveis a seus habitantes, que acabam migrando para áreas submersas. Assim, pode-se inferir que os períodos diários de maré baixa nas colônias do poliqueto pode prejudicar a performance reprodutiva da espécie $P$. monilifer.

Além do habitat, a pressão de predação é um fator que também pode interferir em aspectos reprodutivos. Embora no presente trabalho não tenha sido realizado nenhum experimento da relação entre os organismos que coabitam as colônias do poliqueto e do briozoário, na literatura podem ser encontradas informações que revelem tais relações tróficas.

Segundo Bosa \& Masunari (2002), a composição das espécies deve ser similar em hábitats de complexidade semelhantes. Geralmente, a estrutura trófica dos organismos simbiontes em uma colônia de poliqueto é composta por uma espécie filtradora de Porcellanidae, uma espécie predadora de Xanthoidea e uma onívora, podendo ser representada por um Grapsidae, Paguridae (Gore et al., 1978). Assim, os níveis tróficos no substrato do poliqueto e do briozoário devem ser ocupados pelas mesmas espécies ou por espécies correspondentes.

Alguns trabalhos revelam que associadas ao briozoário são encontradas algumas espécies de Portunidae, Xanthoidea e Grapsidae (Lindberg \& Frydenborg 1980; Mantelatto \& Souza-Carrey, 1998; Morgado \& Tanaka, 2001) e associadas às colônias do poliqueto também são encontradas espécies de Xanthoidea e Grapsidae (Gore et al., 1978; Pinheiro et al. 1997, Bosa \& Masunari, 2002). As espécies da família Portunidae e da superfamília Xanthoidea são indicadas como predadoras do porcelanídeo P. monilifer, (Gore et al., 1978; Mantelatto com. pess). No trabalho de Fausto-Filho \& Furtado (1970) realizado com outra espécie de poliqueto, também revelou uma fauna de Decapoda semelhante à dos trabalhos anteriores. Portanto, devido à semelhança da fauna de Decapoda, a pressão de predação sobre a espécie $P$. monilifer parece ser equivalente em ambos os substratos. 
A espécie Synalpheus sp é citada como coabitante do porcelanídeo Pachycheles (maginanus) rugimanus em colônias do briozoário, inclusive dentro das mesmas câmaras. Essa espécie de camarão possui um comportamento territorialista, porém parece ter desenvolvido um mecanismo de coexistência com o porcelanídeo (Morgado, 1980). Durante as coletas das colônias do poliqueto foi observado que a espécie $P$. monilifer coabita fendas com uma espécie de Alpheidae (gênero Synalpheus), comprovando que hábitats com semelhante complexidade abrigam espécies com nichos ecológico similares.

Uma das relações mais difíceis de ser comprovada é a competição, pois as populações tendem a reduzir ou eliminar esse tipo de relação e também porque as comunidades naturais são espacial e temporariamente variáveis, podendo a competição ser importante em alguns períodos (Pianka, 1976; Wiens, 1977). As espécies $P$. monilifer e $P$. laevidactylus como coabitantes dos dois substratos em estudo são competidoras em potencial por ocuparem o mesmo nicho ecológico. Entretanto, diferenças em relação ao uso do substrato por essas espécies foram encontradas em trabalhos precedentes a este (Pinheiro et al., 1997; Mantelatto \& Souza-Carey, 1998; Hattori, 2000). A espécie $P$. laevidactylus é mais abundante e predominante no substrato do poliqueto, podendo ser evidenciado também pelo menor fitness reprodutivo da espécie em estudo. Por outro lado, no substrato do briozoário a espécie $P$. monilifer é a mais abundante, indicando sua predominância nesse habitat, refletido no maior desempenho reprodutivo.

No trabalho de Alves et al. (2013) foi registrada uma maior diversidade de espécies de Decapoda no briozoário do que no poliqueto (Pinheiro et al., 1997), o que indica maior competição por espaço e também maior pressão de predação nesse habitat. Entretanto, apesar dessas condições menos favoráveis, a espécie em estudo tem um desenvolvimento biológico e reprodutivo de maior sucesso no substrato do briozoário evidenciando sua dominância nesse habitat.

Embora as fêmeas associadas ao poliqueto tenham demonstrado menor potencial reprodutivo, ainda assim asseguram a manutenção, desenvolvimento e sobrevivência da população. O substrato do briozoário, por ser um ambiente fisicamente mais estável, proporciona um menor estresse reprodutivo à espécie. 
A partir das análises das sequências do gene mitocondrial 16S confirmou-se a validade taxonômica de Pachycheles monilifer. As sequências parciais do gene mitocondrial $\mathrm{COI}$ confirmaram a existência do fluxo gênico e o compartilhamento de um único haplótipo entre os organismos das duas populações estudadas. Diante dos dados genéticos é possível afirmar que as diferenças reprodutivas e também de tamanho dos caranguejos são características fenotípicas da espécie.

As populações, sendo geneticamente semelhantes, refletem importantes adaptações locais e a grande plasticidade fenotípica diante às diferentes pressões seletivas encontradas nos substratos. O substrato do briozoário oferece condições mais adequadas para o desenvolvimento e reprodução aos seus simbiontes, ao mesmo tempo que proporciona mais espaço para o crescimento dos caranguejos. As fêmeas do porcelanídeo demonstraram maior crescimento e melhor aptidão reprodutiva, evidenciando a importância dessa colônia para o desenvolvimento e manutenção da espécie.

Por outro lado, no substrato do poliqueto as fêmeas, assim como a população, são menores que os exemplares associados ao briozoário e também possuem um menor potencial reprodutivo. Apesar dessa colônia apresentar condições de maior estresse e possuir espaço mais restrito para os simbiontes, continua sendo um local utilizado para o desenvolvimento, reprodução e sobrevivências do caranguejo porcelanídeo.

Nesse sentido, as duas populações têm o substrato como um fator limitante e decisivo para sua performance reprodutiva, desempenhando um papel importante na história de vida da espécie. 
Referências Bibliográficas 
Abreu, J. 1980. Distribuição e ecologia dos Decapoda numa área estuarina de Ubatuba (SP). Boletim do Instituto Oceanográfico, 29(2): 1-3.

Ahmed, M. \& Mustaquim, J. 1974. Population structure of four species of porcellanid crabs (Decapoda: Anomura) occurring on the coast of Karachi. Marine Biology, 26(2): 173-182.

Alekseev, F. E. 1981. Rass-Thorson - Marshall rule and biological structure of marine communities. In: Vinberg, G. G. (Ed.), 4th Congress of All-Union Hydrobiological Society. Theses of reports. Part I. Naukova Dumka, Kiev: 4-6.

Alves, D. F. R.; Barros-Alves, S. P.; Lima, D. J. M.; Cobo, V. J. \& NegreirosFransozo, M. L. 2013. Brachyuran and anomuran crabs associated with Schizoporella unicornis (Ectoprocta, Cheilostomata) from southeastern Brazil. Anais da Academia Brasileira de Ciências, 85(1): 245-256.

Avise, J. C. 2004. Molecular makers, natural history and evolution. 2nd. Sinauer Associates, Inc. Publishers Sunderland, Massachusetts, USA.

Avise, J. C.; Arnold, J.; Ball, R. M.; Bermingham, E.; Lamb, T.; Neigel, J. E.; Reeb, C. A. \& Saunders, N. C. 1987. Intraspecific phylogeography: the mitochondrial DNA bridge between population genetics and systematics. Annual Review of Ecology and Systematics, 18: 489-522.

Baeza, A. 2008. Social monogamy in the shrimp Pontonia margarita, a symbiont of Pinctada mazatlanica, of the Pacific Coast of Panama. Marine Biology, 153(3): 387-395.

Baeza, J. A. \& Stotz, W. B. 2001. Host-use pattern and host-selection during ontogeny of the commensal crab Allopetrolisthes spinifrons ( $\mathrm{H}$. Milne Edwards, 1837) (Decapoda: Anomura: Porcellanidae). Journal of Natural History, 35(3): 341355.

Baeza, J. A. \& Thiel, M. 2000. Host use pattern and life history of Liopetrolisthes mitra (Dana, 1852), an associate of the black sea urchin Tetrapygus niger (Molina). Journal of Marine Biological Association of United Kingdom, 80(4): 639-645.

Baker, N.; Bruyn, M. \& Mather, P. B. 2008. Patterns of molecular diversity in wild stocks of the redclaw crayfish (Cherax quadricarinatus) from northern Australia and Papua New Guinea: impacts of Plio-Pleistocene landscape evolution. Freshwater Biology, 53(8): 1592-1605.

Balasundaram, C. \& Pandian, T. J. 1982. Egg loss during incubation in Macrobrachium nobilii (Henderson and Mathai). Journal of Experimental Marine Biology and Ecology, 59(2/3): 289-299.

Bandelt, H. J.; Foster, P.; Rohl, A. 1999. Median-joining networks for inferring intraspecific phylogenies. Molecular Biology and Evolution, 16(1): 37-48. 
Bas, C. C. \& Spivak, E. D. 2000. Effect of salinity on embryos of two southwestern Atlantic estuarine Grapsid crab species cultured in vitro. Journal of Crustacean Biology, 20(4): 647-656.

Bauer, R. T. 1991. Analysis of embryo production in a caridean shrimp guild from a tropical seagrass meadow. In Wenner, A. M. \& Kuris, A. M. (eds.), Crustacean Egg Production, 181-191.

Beck, M. W. 1995. Size-Specific shelter limitation in stone crabs: a test of the demographic bottleneck hypothesis. Ecology, 76(3): 968-980.

Berkenbusch, K. \& Rowden, A. A. 2000. Latitudinal variation in the reproductive biology of the burrowing ghost shrimp Callianassa filholi (Decapoda: Thalassinidae). Marine Biology, 136(3): 497-504.

Bloom, S. A. 1975. Motile escape response of a sessile prey: a sponge-scallop mutualism. Journal of Experimental Marine Biology and Ecology, 17(3): 311321.

Boltaña, S. \& Thiel, M. 2001. Associations between two species of snapping shrimp, Alpheus inca and Alpheopsis chilensis (Decapoda: Caridea: Alpheidae). Journal of the Marine Biological Association of the United Kingdom, 81(4): 633-638.

Boolootian, R. A.; Giese, A. C.; Farmanfarmain, A. \& Tucker, J. 1959. Reproductive cycles of five west coast crabs. Physiological Zoology, 32(2): 13-220.

Bosa, C. R. \& Masunari, S. 2002. Crustáceos decápodos associados aos bancos de Phragmatopoma caudata (Kröyer) (Polychaeta, Sabellariidae) na Praia de Caiobá, Matinhos, Paraná. Revista brasileira de Zoologia, 19(1): 117-133.

Branco, J. O. \& Avilar, M. G. 1992. Fecundidade em Callinectes danae Smith (Decapoda, Portunidae) da Lagoa da Conceição, Florianópolis, Santa Catarina, Brasil. Revista Brasileira de Zoologia, 9(3/4): 167-173.

Brante, A.; Fernández, M.; Eckerle, L. Mark, F.; Pörtner, H. O. \& Arntz, W. 2003. Reproductive investment in the crab Cancer setosus along a latitudinal cline: egg production, embryo losses and embryo ventilation. Marine Ecology Progress Series, 251:221-232.

Brody, M. S. 1991. Variation in reproductive output of the isopod Armadillidium vulgare. In: Wenner, A. M. \& Kuris, A. M. Crustacean egg production, 171-179.

Caddy,J. F. 1986. Modelling stock-recruitment processes in Crustacea: some practical and theoretical perspectives. Canadian Journal of Fisheries and Aquatic Sciences, 43: 2330-2344.

Caddy, J. F. 1989. Marine invertebrates fisheries: their assessment and management. John Wiley \& Sons, New York, 752pp. 
Caddy, J. F. \& Stamatopoulas, C. 1990. Mapping growth and mortality rates of crevice-dwelling organisms onto a perforated surface: the relevance of 'cover' to carrying capacity of natural and artificial habitats. Estuarine, Coastal and Shelf Science, 31(1): 87-106.

Carvalho-Batista, A. 2013. Dinâmica populacional e análise da variação genética do camarão barba-ruça Artemesia longinaris Spence Bate, 1888 (Crustacea, Penaeidae). Dissertação de mestrado. UNESP, Botucatu. 99pp.

Castro-Filho, B. M.; Miranda, I. B. \& Myao, S. Y. 1987. Condições hidrográficas na plataforma continental ao largo de Ubatuba: variações sazonais e em média escala. Boletim do Instituto Oceanográfico, 35(2): 135-151.

Chester, C. M. 1996. The effect of adult nutrition on the reproduction and development of the estuarine nudibranch, Tenellia adspersa (Nordmann, 1845). Journal of Experimental Marine Biology and Ecology, 198(1): 113-130.

Clarke, A. 1987. Temperature, latitude and reproductive effort. Marine Ecology Progress Series, 38: 89-99.

Clarke, A. 1988. Seasonality in the Antarctic marine environment. Comparative Biochemistry and Physiology, 90B(3): 461-473.

Clarke, A.; Hopkins, C. C. E. \& Nilssen, E. M. 1991. Egg size and reproductive output in the deep water prawn Pandalus borealis Kröyer, 1838. Functional Ecology, 5(6): 724-730.

Clement, M.; Posada, D. \& Crandall, K. A. 2000. TCS: a computer program to estimate gene genealogies. Molecular Ecology, 9(10): 1657-1660.

Cocito, S.; Ferdeghini, F.; Morri, C. \& Bianchi, N. C. 2000. Patterns of bioconstruction in the cheilostome bryozoan Schizoporella errata: the influence of hydrodynamics and associated biota. Marine Ecology Progress Series, 192: 153-161.

Daniels, S. R. 2003. Examining the genetic structure among populations of the common cape river crab Potamonautes perlatus from river systems in South Africa reveals hydrographic boundaries. Journal of Crustacean Biology, 23(4): 936-950.

Efford, I. E. 1969. Egg size in the sand crab, Emerita analoga (Decapoda, Hippidae). Crustaceana, 16(1):15-26.

Excoffier, L.; Laval, G. \& Scheneider, S. 2005. Arlequin (version 3.0): an integrated software package for population genetics data analysis. Evolutionary Bioinformatics Online, 1: 47-50. 
Fausto-Filho, J. \& Furtado, E. 1970. Nota preliminar sobre a fauna de colônias de Sabellariidae do litoral do Estado do Ceará (Annelida, Sedentaria). Revista Brasileira de Biologia, 30: 285-289.

Felsenstein, J. 1985. Confidence limits on phylogenies: an approaching using the bootstrap. Evolution, 39(4): 783-791.

Ferreira, L. A. A. 2010. Taxonomia e distribuição da família Porcellanidae Haworth (Crustacea: Decapoda: Anomura) no litoral brasileiro. Dissertação de mestrado. UNESP, Rio Claro. 232 pp.

Ferreira, L. A. \& Melo, G. A. S. 2010. On an invalid record of Pachycheles chacei Haig, 1956, from the southwestern Atlantic (Decapoda: Anomura: Porcellanidae). Nauplius, 18(2): 143-145.

Figueiredo, J.; Penha-Lopes, G.; Anto, J.; Narciso, L. \& Lin, J. 2008. Fecundity, brood loss and egg development through embryogenesis of Armases cinereum (Decapoda: Grapsidae). Marine Biology, 154(2): 287-294.

Francisco, A. K. \& Galetti-Junior, P. M. 2005. Genetic distance between broodstocks of the marine shrimp Litopenaeus vannamei (Decapoda, Penaeidae) by mtDNA analyses. Genetics and Molecular Biology, 28(2): 258-261.

Fransozo, A. \& Bertini, G. 2001. Population structure and breeding period of Pachycheles monilifer (Dana) (Anomura, Porcellanidae) inhabiting sabellariid sand reefs from the littoral coast of São Paulo State, Brazil. Revista Brasileira de Zoologia, 18(1): 187-203.

Fransozo, A.; Mantelatto, F. L.; Bertini, G.; Fernandez-Góes, L. C. \& Martinelli, J. M. 1998. Distribution and assemblage of anomuran crustaceans in Ubatuba Bay, north coast of São Paulo state, Brazil. Acta Biologica Venezuelica, 18(4): 17-25.

Gore, R. H. 1973. Pachycheles monilifer (Dana, 1852): the development in the laboratory of larvae from an Atlantic specimen with a discussion of some larval characters in the genus (Crustacea: Decapoda; Anomura). Biology Bulletin, 144: $132-150$.

Gore, R. H. \& Abele, L. G. 1976. Shallow water porcelain crabs from the Pacific Coast of Panama and adjacent Caribbean waters (Crustacea: Anomura: Porcellanidae). Smithsonian Contributions to Zoology, 237: 1-30.

Gore, R. H.; Scotto, L. E. \& Becker, L. J. 1978. Community composition, stability and trophic partitioning in decapod crustaceans inhabiting some subtropical sabellariid worm reefs. Bulletin Marine Science, 28(2): 221-248. 
Gusso-Chimenz C. \& Rivosecchi-Taramelli, E. 1972. Contributo alla conoscenza dei briozoi del porto di Civitavecchia. Atti $\vee$ Congresso Nazionale della Società Italiana di Biologia Marina SIBM Genova, 66-101.

Haig, J. 1960. The Porcellanidae (Crustacea: Anomura) of the Eastern Pacific. Allan Hancock Pacific Expedition, 24: 1-440.

Harrison, J. S. 2004. Evolution, biogeography, and the utility of mitochondrial 16S and $\mathrm{COI}$ genes in phylogenetic analysis of the crab genus Austinixia (Decapoda: Pinnotheridae). Molecular Phylogenetics and Evolution, 30(3): 743-754.

Harrison, K. E. 1990. The role of nutrition in maturation, reproduction and embryonic development of Decapoda crustaceans: a review. Journal of Shellfish Research, 9(1): 1-28.

Hartnoll, R. G. 2006. Reproductive investment in Brachyura. Hydrobiologia, 184(3): 31-40.

Hattori, G. Y. 2000. Fecundidade e embriologia de Pachycheles monilifer (Dana, 1852) (Crustacea: Anomura: Porcellanidae). Trabalho de Conclusão de Curso. UNESP, Jaboticabal. 53pp.

Hattori, G. Y. \& Pinheiro, M. A. A. 2001. Fecundity and embriology of Pachycheles monilifer (Dana, 1852) (Anomura, Porcellanidae) at Praia Grande, Ubatuba, SP, Brazil. Nauplius, 9(2): 97-109.

Hernáez, P. \& Palma, S. 2003. Fecundidad, volumen del huevo y rendimiento reproductivo de cinco especies de porcelánidos intermareales del norte de Chile (Decapoda, Porcellanidae). Investigaciones Marinas, 31(2): 35-46.

Hernáez-Bové, P. \& Pinheiro, M. A. A. 2001. Production and reproductive output of four porcelain crab species from northern Chile. Nauplius, 9(1): 43-52.

Hernáez-Bové, P. 2001. Producción y rendimiento reproductivo en Petrolisthes granulosus (Decapoda, Anomura, Porcellanidae) en diferentes localidades del norte de Chile: una comparación latitudinal. Investigaciones Marinas, 29(1): 7381.

Hines, A. H. 1982. Coexistence in a kelp forest: size, population dynamics, and resource partitioning in a guild of spider crabs (Brachyura, Majidae). Ecological Monographs, 52(2): 179-198.

Hines, A. H. 1988. Fecundity and reproductive output in two species of deep sea crabs, Geryon fenneri and G. quinquedens (Decapoda: Brachyura). Journal of Crustacean Biology, 8(4): 557-562.

Hines, A. H. 1991. Fecundity and reproductive output in nine species of Cancer crabs (Crustacea, Brachyura, Cancridae). Canadian Journal of Fisheries and Aquatic Sciences, 48(2): 267-275. 
Hines, A. H. 1992. Constraints on reproductive output in brachyuran crabs: pinnotherids test the rule. American Zoologist, 32(3): 503-511.

Howard, A. E. 1980. Substrate controls on the size composition of lobster (Homarus gammarus) populations. Journal du Conseil, 39(2): 130-133.

Jensen, J. P. 1958. The relation between body size and numbers of eggs in marine malacostrakes. Meddelelser fra Danmarks fisheri-og havundersøgelser, NY Serie, 2: 1-25.

Jones, M. B. 1977. Breeding and seasonal population changes of Petrolisthes elongates (Crustacea, Decapoda, Anomura) at Kaikoura, New Zealand. Journal of the Royal Society of New Zealand, 7(3): 259-272.

Jones, M. B. \& Simons, M. J. 1983. Latitudinal variation in the reproductive characteristics of a mud crab, Helice crassa (Grapsidae). Bulletin of Marine Science, 33(3): 656-670.

Kasyanov, V. L. 1999. Reproductive strategy in marine bivalves and echinoderms. Oxonian Press, New Delhi, 229 pp.

Kinne, O. 1961. Growth, molting frequency, heart beat, number of eggs, and incubation time in Gammarus zaddachi exposed to different environments. Crustaceana, 2(1): 26-36.

Knowlton, N. 1980. Sexual selection and dimorphism in two demes of a symbiotic, pair-bonding snapping shrimp. Evolution, 34(1): 161-173.

Knowlton, N. 2000. Molecular genetic analyses of species boundaries in the sea. Hydrobiologia, 420: 73-90.

Knowlton, N.; Weight, L. A.; Solorzano, L. A.; Mills, K. D. \& Bermingham, E. 1993. Divergence in proteins, mitochondrial DNA, reproductive compatibility across the Isthmus of Panama. Science, New Series, 260(5114): 1629-1632.

Kropp, R. K. 1981. Additional porcelain crab feeding methods (Decapoda, Porcellanidae). Crustaceana, 40(3): 307-310.

Kuris, A. M. 1991. A review of patterns and causes of crustacean brood mortality. In: Wenner, A. M. \& Kuris, A. M. (Eds.), Crustacean Egg Production, 117-141.

Laptikhovsky, V. 2005. Latitudinal and bathymetric trends in egg size variation: a new look at Thorson's and Rass's rules. Marine Ecology, 27(1): 7-14.

Lardies, M. A. \& Castilla, J. C. 2001. Latitudinal variation in the reproductive biology of the commensal crab Pinnaxodes chilensis (Decapoda: Pinnotheridae) along the Chilean coast. Marine Biology, 139(6): 1125-1133.

Lardies, M. A. \& Wehrtmann, I. S. 1996. Aspects of the reproductive biology of Petrolisthes laevigatus (Guerin, 1835) (Decapoda: Anomura: Porcellanidae). I. 
Reproductive output and chemical composition of eggs during embryonic development. Archive of Fishery and Marine Research, 43(2): 121-135.

Lardies, M. A. \& Wehrtmann, I. S. 2001. Latitudinal variation in the reproductive biology of Betaeus truncatus (Decapoda: Alpheidae) along the Chilean coast, Ophelia, 55(1): 55-67.

Leme, M. H. A. \& Negreiros-Fransozo, M. L. 1998. Fecundity of Aratus pisonii (Decapoda, Grapsidae) in Ubatuba regions, state of São Paulo, Brazil. Iheringia, Série Zoologia, 84: 73-77.

Lessios, H. A. 1990. Adaptation and phylogeny as determinants of egg size in echinoderms from the two sides of the Isthmus of Panama. The American Naturalist, 135(1): 1-13.

Lindberg, W. J. \& Frydenborg, R. B. 1980. Resource centered agonism of Pilumnus sayi (Brachyura, Xanthidae), an associate of the bryozoan Schizoporella pungens. Behaviour, 75(3/4): 235-250.

Lindley, J. A. 1990. Regressions for estimating development times of the pelagic larvae of Paguridae and Porcellanidae. Journal of Plankton Research, 12(3): 673-678.

Liu, M. Y.; Cai, Y. X. \& Tzeng, C. S. 2007. Molecular systematics of the freshwater prawn genus Macrobrachium Bate, 1868 (Crustacea: Decapoda: Palaemonidae) inferred from mtDNA sequences, with emphasis on East Asian species. Zoological Studies, 46(3): 272-289.

López, L.; Jeri, T.; González, C. \& Rodríguez, S. 1997. Fecundidad y esfuerzo reproductivo de Petrolisthes granulosus (Guérin, 1835) en Iquique, Chile (Decapoda, Anomura, Porcellanidae). Investigaciones Marinas, 25: 159-165.

Mantelatto, F. L. \& Fransozo, A. 1997. Fecundity of the crab Callinectes ornatus Ordway, 1863 (Decapoda, Brachyura, Portunidae) from the Ubatuba region, São Paulo, Brazil. Crustaceana, 70(2): 214-226.

Mantelatto, F. L. \& Fransozo, A. 1999. Characterization of the physical and chemical parameters of Ubatuba Bay, northern coast of São Paulo state, Brazil. Revista Brasileira de Biologia, 59 (1): 23-31.

Mantelatto, F. L. \& Fransozo, A. 2000. Brachyuran community in Ubatuba Bay, northern coast of São Paulo state, Brazil. Journal of Shellfish Research, 19(2): 701-709.

Mantelatto, F. L. \& Garcia, R. B. 1999. Reproductive potential of the hermit crab Calcinus tibicen (Anomura) from Ubatuba, São Paulo, Brazil. Journal of Crustacean Biology, 19(2): 268-275. 
Mantelatto, F. L. \& Souza-Carrey, M. M. 1998. Brachyura (Crustacea, Decapoda) associated to Schizoporella unicornis (Bryozoa, Gymnolaemata) in Ubatuba Bay (SP), Brazil. Brazilian Archives of Biology and Technology, 41(2): 212-217.

Mantelatto, F. L.; Robles, R.; Biagi, R. \& Felder, D. L. 2006. Molecular analysis of the taxonomic and distributional status for the hermit crab genera Loxopagurus Forest, 1964 and Isocheles Stimpson, 1858 (Decapoda, Anomura, Diogenidae). Zoosystema, 28(2): 495-506.

Mantelatto, F. L.; Robles, R. \& Felder, D. L. 2007. Molecular phylogeny of the Western Atlantic species of the genus Portunus (Crustacea, Brachyura Portunidae). Zoological Journal of the Linnean Society, 150(1): 211-220.

Mantelatto, F. L.; Pardo, L. M.; Pileggi, L. G. \& Felder D. L. 2009a. Taxonomic reexamination of the hermit crabs species Pagurus forceps and Pagurus comptus (Decapoda: Paguridae) by molecular analysis. Zootaxa, 2133: 20-32.

Mantelatto, F. L.; Robles, R.; Schubart, C. D. \& Felder, D. L. 2009b. Molecular phylogeny of the genus Cronius Stimpson, 1860, with reassignment of $C$. tumidulus and several American species of Portunus to the genus Achelous De Haan, 1833 (Brachyura: Portunidae). In: Martin, J. W.; Crandall, K. A. \&. Felder, D. L (Eds.). Decapod Crustacean Phylogenetics. Taylor and Francis/CRC Press, Boca Raton, Crustacean Issues, 18: 567-579.

Mantelatto, F. L.; Pileggi, L. G.; Miranda, I. \& Wehrtmann, I. 2011. Does Petrolisthes armatus (Anomura, Porcellanidae) form a species complex or are we dealing with just one widely distributed species? Zoological Studies, 50(3): 372-384.

Masunari, S.; Oliveira, E. \& Kowalczuk, V. G. L. 1998. Crustacea Decapoda da praia Rochosa da llha do Farol, Matinhos, Paraná. I. Distribuição temporal de densidade das populações. Revista Brasileira de Zoologia, 15(1): 219-239.

Melo, G. A. S. 1999. Manual de identificação dos Crustacea Decapoda do litoral brasileiro: Anomura, Thalassinidea, Palinuridea, Astacidea. São Paulo: Plêiade/FAPESP, $551 \mathrm{pp}$.

Micheletti-Flores, C. V. \& Negreiros-Fransozo, M. L. 1999. Porcellanid crabs (Crustacea, Decapoda) inhabiting sand reefs built by Phragmatopoma lapidosa (Polychaeta, Sabellariidae) at Paranapuã Beach, São Vicente, SP, Brazil. Revista Brasileira de Biologia, 59(1): 63-73.

Miranda, I. \& Mantelatto, F. L. 2009. Estimating population features of the anomuran crab Petrolisthes armatus (Porcellanidae) in a remaining and impacted mangrove area of the Western Atlantic. Journal of Natural History, 43(33/34): 2027-2039. 
Miranda, I. \& Mantelatto, F. L. 2010a. Sexual maturity and relative growth of the porcellanid crab Petrolisthes armatus (Gibbes, 1850) from a remnant mangrove area southern Brazil. Nauplius, 18(1): 87-93.

Miranda, I. \& Mantelatto, F. L. 2010b. Temporal dynamic of the relationship between the parasitic isopod Aporobopyrus curtatus (Crustacea: Isopoda: Bopyridae) and the anomuran crab Petrolisthes armatus (Crustacea: Decapoda: Porcellanidae) in southern Brazil. Latin American Journal of Aquatic Research, 38(2): 210-217.

Miranda, I.; Meireles, A. L.; Biagi, R. \& Mantelatto, F. L. 2006. Is the abundance of the red brocade hermit crab Dardanus insignis (Decapoda: Anomura: Diogenidae) in the infralitoral region of southern Brazil determined by reproductive potential? Crustacean Research, 6(1): 45-55.

Morgado, E. H. \& Tanaka, M. O. 2001. The macrofauna associated with the bryozoan Schizoporella errata (Walters) in southeastern Brazil. Scientia Marina, 65(3): 173-181.

Morgado, E. H. 1980. A endofauna de Schizoporella unicornis (Johnston, 1847) (Bryozoa), no litoral norte do Estado de São Paulo. Dissertação de Mestrado. UNICAMP. 125pp.

Moritz, C.; Dowling, T. E. \& Brown, W. M. 1987. Evolution of animal mitochondrial DNA: relevance for population biology and systematics. Annual Review of Ecology and Systematics, 18:269-292.

Narchi, W. \& Rodrigues, S. A. 1965. Observações ecológicas sobre Phragmatopoma lapidosa Kinberg. Ciência e Cultura, São Paulo, 17: 228-229.

Negreiros-Fransozo, M. L.; Fransozo, A.; Pinheiro, M. A. A.; Mantelatto, F. L. \& Santos, S. 1991. Caracterização física e química da Enseada da Fortaleza, Ubatuba, SP. Revista Brasileira de Geografia, 21(2): 114-120.

Nelson, B. W. 1962. Important aspects of estuarine sediment chemistry for benthic ecology. In: Symposium on the environmental chemistry of marine sediments. University of Rhode Island, 1: 27-41.

Ogawa, E. F. \& Rocha, C. A. S. 1976. Sobre a fecundidade de crustáceos decápodos marinhos do Estado do Ceará, Brasil. Arquivo de Ciências do Mar, 16(2): 101104.

Oh, C. W. \& Hartnoll, R. G. 1999. Size at sexual maturity, reproductive output, and seasonal reproduction of Philocheras trispinosus (Decapoda) in the Port Erin Bay, Isle of Man. Journal of Crustacean Biology, 19(2): 252-259. 
Oh, C. W., \& Hartnoll, R. G. 2004. Reproductive biology of the common shrimp Crangon crangon (Decapoda: Crangonidae) in the central Irish Sea. Marine Biology 144(2): 303-316.

Oliveira, E. \& Masunari, S. 1995. Estrutura populacional de Petrolisthes armatus (Gibbes) (Decapoda, Anomura, Porcellanidae) da llha do Farol, Matinhos, Paraná, Brasil. Revista Brasileira de Zoologia, 12(2): 355-371.

Osawa, M. \& Mclaughlin, P. A. 2010. Annotated checklist of Anomuran Decapod Crustacean (exclusive of the Kiwaoidea and families Chirostylidae and Galatheidae of Galatheoidea) Part II - Porcellanidae. The Raffles Bulletin of Zoology, 23: 109-129.

Osman, R. W. \& Haugsness, J. A. 1980. Mutualism among sessile invertebrates: a mediator of competition and predation. Science, 211(4484): 846-848.

Palumbi, S. R.; Benzie, J. 1991. Large mitochondrial DNA differences between morphologically similiar penaeid shrimp. Molecular Marine Biology and Biotechnology, 1(1): 27-34.

Pardo, L. M.; Piraud, F.; Mantelatto, F. L. \& Ojeda, F. P. 2007. Ontogenetic pattern of resource use by the tiny hermit crab Pagurus villosus (Paguridae) from the temperate Chilean coast. Journal of Experimental Marine Biology and Ecology, 353(1): 68-79.

Patton, W. K., Patton, R. J. \& Barnes, A. 1985. On the biology of Gnathophylloides mineri, a shrimp inhabiting the sea urchin Tripneustes ventricosus. Journal of Crustacean Biology, 5(4): 616-626.

Pavanelli, C. A. M.; Mossolin, E. C. \& Mantelatto, F. L. 2008. Reproductive strategy of the snapping shrimp Alpheus armillatus $\mathrm{H}$. Milne Edwards, 1837 in the South Atlantic: fecundity, egg features, and reproductive output. Invertebrate Reproduction and Development, 52(3): 123-130.

Peiró, D. F. 2012. Status taxonômico de Callichirus major (Say, 1818) sensu lato (Crustacea, Decapoda, Axiidea, Callianassidae) da costa brasileira: brasileira: taxonomia, sistemática molecular, biologia populacional e reprodutiva. Tese de Doutorado. USP, Ribeirão Preto. 155pp.

Pianka, E. R. 1976. Competition and niche theory. In: May, R. M. \& Saunders, W. B. (Eds), Theoretical Ecology: Principles and Applications, 114-141.

Pileggi, L. G. \& Mantelatto, F. L. 2010. Molecular phylogeny of the freshwater prawn genus Macrobrachium (Decapoda, Palaemonidae), with emphasis on the relationships among selected american species. Invertebrate Systematics, 24(2): 194-208. 
Pinheiro, M. A. A. \& Fransozo, A. 1995. Fecundidade de Pachycheles haigae Rodrigues da Costa, 1960 (Crustacea, Anomura, Porcellanidae) em Ubatuba, SP, Brasil. Revista Brasileira de Biologia, 55(4): 623-631.

Pinheiro, M. A. A.; Fransozo, A. \& Negreiros-Fransozo, M. L. 1994. Estimativa da duração larval em função da temperatura para a família Majidae (Crustacea, Decapoda, Brachyura). Boletim do Instituto de Pesca, 21: 75-81.

Pinheiro, M. A. A.; Bertini, G.; Fernandes-Góes, L. C. \& Fransozo, A. 1997. Decapod crustaceans associated to sand reefs of Phragmatopoma lapidosa Kinberg, 1867 (Polychaeta, Sabellariidae) at Praia Grande, Ubatuba, SP, Brazil. Nauplius, 5(2): 77-83.

Rass, T. S. 1941. Geographic parallelisms in morphology and development of teleost fish of Northern Seas. MOIP, Moscow.

Rass, T. S. 1986. Biogeographic rule of inverse relation between egg size and environmental temperature in poikilothermous animals. Trudy IOAN, 116: 152168.

Reid, D. M. \& Corey, S. 1991. Comparative fecundity of decapod crustaceans, II. The fecundity of fifteen species of anomuran and brachyuran crabs. Crustaceana, 61(2): 175-189.

Robles, R.; Schubart, C.; Conde, J. E.; Carmona-Suárez, C.; Alvarez, F.; Villalobos, J. L. \& Felder, D. L. 2007. Molecular phylogeny of the American Callinectes Stimpson, 1860 (Brachyura: Portunidae), based on two partial mitochondrial genes. Marine Biology, 150(6): 1265-1274.

Rodríguez, I. T.; Hernandéz, G. \& Felder, D. L. 2005. Review of Western Atlantic Porcellanidae with new records, systematic observations, and comments on biogeography. Caribbean Journal of Science, 41(3): 544-582.

Ross, D. M. 1983. Symbiotic relations. In: Vernberg, S. J. \& Vernberg, W. B. (Eds). The Biology of Crustacea. New York, Academic Press, 7: 163-212.

Roughgarden, J. \& Pacala, W. S. 1982. The evolution of resource partitioning in a multidimensional resource space. Theoretical Population Biology, 22(1): 127145.

Rozas, J. \& Rozas, R. 1999. DnaSP version 3.0: an integrated program for molecular population genetics and molecular evolution analysis. Bioinformatics, 15(2): 174-175.

Sandoz, M \& Hopkins, S. H. 1947. Early life history of the oyster crab, Pinnotheres ostreum (say). Biology Bulletin, 93(3): 250-258.

Sandifer, P. A. 1972. Growth of young oyster crabs, Pinnotheres ostreum Say, reared in the laboratory. Chesapeake Science, 13(3): 221-222. 
Sastry, A. N. 1983. Ecological aspects on reproduction. In: Vernberg, F. J. \& Vernberg, W. B. (Eds). The Biology of Crustacea. New York, Academic Press, 8: 179-255.

Scelzo, M. A. 1985. Biología y morfometria del cangrejo Petrolisthes politus (Gray, 1831) (Anomura, Porcellanidae) de la Isla Cubagua, Venezuela. Boletín Del Instituto Oceanográfico Universidad Del Oriente, 24(1): 63-74.

Schubart, C. D. 2009. Mitochondrial DNA and decapod phylogenies: the importance of pseudogenes and primer optimization. In: Martin, J. W.; Crandall, K. A \& Felder, D. L. (Eds), Decapod Crustacean Phylogenetics. Crustacean Issues. London, CRC Press, 18: 47-65

Schubart, C. D. \& Huber, M. G. J. 2006. Genetic comparisons of German populations of the stone crayfish, Austropotamobius torrentium (Crustacea: Astacidae). Bulletin Français de la Pêche et de la Pisciculture, 380-381: 10191028.

Schubart, C. D.; Neigel, J. E. \& Felder, D. L. 2000. Use of the mitochondrial 16S rRNA gene for phylogenetic and population studies of Crustacea. Crustacean Issues, 12: 817-830.

Shakuntala, K. 1977. The Relation between body size and number of eggs in the freshwater prawn, Macrobrachium lamarrei (H. Milne Edwards) (Decapoda, Caridea). Crustaceana, 33(1): 17-22.

Shuster, S. M. 1987. Alternative reproductive behaviors: three discrete male morphs in Paracerceis sculpta, an intertidal isopod from the northern Gulf of California. Journal of Crustacean Biology, 7(2): 318-327.

Silva, I. M. 2011. Relações filogenéticas entre Pachycheles (Stimpson, 1858) e Neopisosoma Haig, 1960 (Decapoda, Anomura, Porcellanidae) e revisão taxonômica de Pachycheles da costa brasileira. Tese de Doutorado, USP, Ribeirão Preto,127 pp.

Slatkin, M. 1987. Gene flow and the geographic structure of natural populations. Science, 236: 787-792.

Somers, K. M. 1991. Characterizing size-specific fecundity in crustaceans. In: Schram, F. R. (Ed). Crustacean egg production. A. A. Balkema, Rotterdam. Crustacean Issues, 7: 357-378.

Stebbins, T. D. 1989. Population dynamics and reproductive biology of the commensal isopods Calidotea rostrata (Crustacea: Isopoda: Idoteidae). Marine Biology, 101(3): 329-337.

Stevcic, Z. 1988. Autoecological investigations of the Porcelain crab Porcellana platycheles (Pennant) (Decapoda,Anomura) in the Rovinj Area (Northern Adriatic). Crustaceana, 55(3): 242-252. 
Stimson, J. 1990. Stimulation of fat-body production in the polyps of the coral Pocillopora damicornis by the presence of mutualistic crabs of the genus Trapezia. Marine Biology, 106(2): 211-218.

Tamura, K.; Peterson, D.; Peterson, N.; Stecher, G.; Nei, M. \& Kumar, S. 2011. MEGA 5: Molecular evolutionary genetics analysis using maximum likelihood, evolutionary distance, and maximum parsimony methods. Molecular Biology and Evolution, 28: 2731-2739.

Terossi, M. \& Mantelatto, F. L. 2010. Sexual ratio, reproductive period and seasonal variation of the gonochoric shrimp Hippolyte obliquimanus (Caridea: Hippolytidae). Marine Biology Research, 6(2): 213-219.

Terossi, M.; Wehrtmann, I. S. \& Mantelatto, F. L. 2010. Interpopulation comparison of reproduction of the Atlantic shrimp Hippolyte obliquimanus (Caridea: Hippolytidae). Journal of Crustacean Biology, 30(4): 571-579.

Thiel, M. \& Baeza, J. A. 2001. Factors affecting the social behavior of symbiotic Crustacea: a modeling approach. Symbiosis, 30(2/3): 163-190.

Thiel, M. \& Duffy, J. E. 2007. The behavioral ecology of crustaceans: a primer taxonomy, morphology and biology. In: Duffy, J. E. \& Thiel, M., Evolutionary ecology of social and sexual systems: crustaceans as model organisms. Oxford University Press, New York, 3-28.

Thiel, M.; Zander, A.; Valdivia, N.; Baeza, J. A. \& Rueffler, C. 2003. Host fidelity of a symbiotic porcellanid crab: the importance of host characteristics. Journal of Zoology London, 261(4): 353-362.

Thompson, J. D.; Higgins, D. G. \& Gibson, T. J. 1994. CLUSTAL W: improving the sensitivity of progressive multiple sequence alignment through sequence weighting, position-specific gap penalties and weight matrix choice. Nucleic Acids Research, 22(22): 4673-4680.

Thorson, G. 1936. The larval development, growth, and metabolism of Arctic marine bottom invertebrates compared with those of other seas. Meddelelser om Grenland, 100(6): 1-155.

Thorson, G. 1946. Reproduction and larval development of danish marine invertebrates, with special reference to the planktonic larvae in the Sound (Øresund). Meddelingen fra Komision Danmarks Fiskeri-og Havundersøgelser, 4, 1-523.

Thorson, G. 1950. Reproductive and larval ecology of marine invertebrates. Biological Review, 25(1): 1-45.

Tinkle, D. W. \& Hadley, N. F. 1975. Lizard reproductive effort: caloric estimates and comments on its evolution. Ecology, 56(2): 427-434. 
Torati, L. S. \& Mantelatto, F. L. 2008. Uncommon mechanism of egg incubation in the endemic Southern hermit crab Loxopagurus loxochelis: how is this phenomenon related to egg production? Acta Zoologica, 89(1): 79-85.

Turner, R. L. \& Lawrence, J. M. 1979. Volume and composition of echinoderm eggs: implications for use of eggs size in life-history models. In: Stancky, S. E. (Ed.). Reproductive Ecology of Marine Invertebrates. University of South Carolina Press, Columbia, 25-40.

Vance, R. R. 1978. A mutualistic interaction between a sessile marine clam and its epibionts. Ecology, 59(4): 679-685.

Vannini, M. 1985. A shrimp that speaks crab-ease. Journal of Crustacean Biology, 5(1): 160-167.

Veloso, V. G. \&. Melo G. A. S. 1993. Taxonomia e distribuição da família Porcellanidae (Crustacea, Decapoda, Anomura) no litoral brasileiro. Iheringia, Série Zoológica, 75: 171-186.

Vergamini, F. G.; Plieggi, L. G. \& Mantelatto, F. L. 2011. Genetic variability of the Amazon River prawn Macrobrachium amazonicum (Decapoda, Caridea, Palaemonidae). Contributions to Zoology, 80(1): 67-83.

Vermeij, G. J. 1983. Intimate Associations and Coevolution in the Sea. In: Futuyma, D.J. \& Slatkin, M. (Eds). Sinauer Associates, Sunderland. Coevolution, 311327.

Via, S. \& Lande, R. 1985. Genotype-environment interaction and the evolution of phenotypic plasticity. Evolution 39(3): 505-522.

Vogel, S. 1988. Life's devices: the physical world of animals and plants. Princeton University Press, Princeton, 384pp.

Wehrtmann, I. \& Andrade, G. 1998. Egg production in Heterocarpus reedi from northern Chile with a comparison between iced and living females. Ophelia, 49(1): 71-82.

Wehrtmann, I.; Miranda, I.; Lizana-Moreno, C. A.; Hernáez, P.; Barrantes-Echandi, V. \& Mantelatto, F.L. 2011. Reproductive plasticity in Petrolisthes armatus (Anomura, Porcellanidae): a comparison between a Pacific and an Atlantic population. Helgoland Marine Research, 66(1): 87-96.

Weis, V. M.; Reynolds; W. S., de Boer, M. D. \& Krupp, D. A. 2001. Host-symbiont specificity during onset of symbiosis between the dinoflagellates Symbiodinium spp. and planula larvae of the scleractinian coral Fungia scutaria. Coral Reefs, 20(1): 301-308. 
Werding, B.; Hiller, A. \& Lemaitre, R. 2003. Geographic and depth distributional patterns of western Atlantic Porcellanidae (Crustacea: Decapoda: Anomura), with an updated list of species. Memoirs of Museum Victoria, 60(1): 79-85.

Wiens, J. A. 1977. On competition and variable environments. American Scientist, 65(5): 590-597.

Williams, A. B. 1984. Shrimps, lobsters and crabs of the Atlantic coast of the eastern United States, Maine to Florida. Washingtin D.C. Smithsonian Institution Press.

Wilson, W. H. 1979. Community structure and species diversity of the sedimentary reefs constructed by Petaloproctus socialis (Polychaeta: Maldanidae). Journal of Marine Research, 37(4): 623-641. 